Eduardo Sanches Pereira do Nascimento

\title{
Ésteres em aguardente de cana: seu perfil
}

Dissertação apresentada ao Instituto de Química de São Carlos, da Universidade de São Paulo para a obtenção do título de Mestre em Ciências (Química Analítica).

Orientador: Prof. Dr. Douglas Wagner Franco 


\section{DEDICATÓRIA}

Dedica este tralealha à tada minha familia e amigas par estarem sempre camiga em tadas as mamentas importantes da vida. 


\section{EPÍGRAFE}

"Deus nas fez perfeitas e nãa escalthe as capacitadas, capacita as escalhidas. Fazer an nãa fazer alga sá depende de nassa vantade e perseverança."

Albert Einstein 


\section{AGRADECIMENTOS}

À Deus,

À minha vó Rosa, minha mãe Fátima, minha irmã Eloísa e ao Jair, por todo amor, força e dedicação em todos os momentos da minha vida.

À todos os amigos do LDQA, Alexandre, Carlos, Daniel, Ellen, Ivonete, Luciana, Manassés, Olívia, Roni, Silmara e Wendel, pela colaboração, discussões e amizade.

Ao Prof. Dr. Douglas Wagner Franco pela orientação e ensinamentos transmitidos durante a realização deste trabalho.

Às amigas secretárias Rosana e Veroneide, pela amizade, alegria e auxílio na realização deste trabalho.

À todos os meus familiares, pela alegria que sentem em todas as minhas conquistas e por tudo que sempre fizeram por mim.

À todos os meu amigos, em especial à aqueles que adquiri em Mirandópolis, Campo Grande e São Carlos, por estarem ao meu lado nos momentos mais importantes da minha vida. 
Às funcionárias da Coordenação da pós-graduação Silvia e Andréia, pelo atendimento atencioso.

À todos os funcionários do IQSC que sempre auxiliaram na prestação de esforços para a realização deste trabalho.

Ao CNPq pela bolsa concedida. 


\section{SUMÁRIO}

LISTA DE FIGURAS

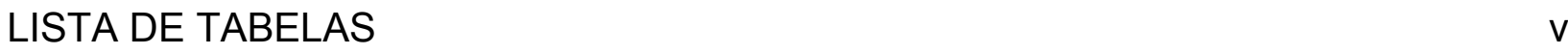

LISTA DE ANEXOS Vii

RESUMO viii

ABSTRACT 1 x

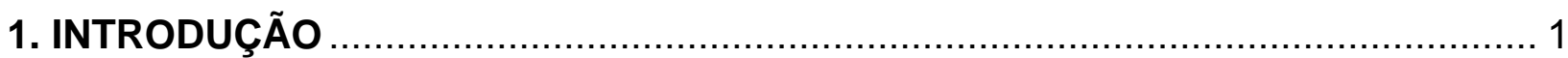

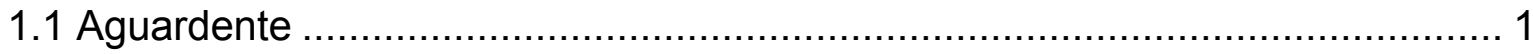

1.1.1 Regulamentações da aguardente de cana brasileira ........................ 1

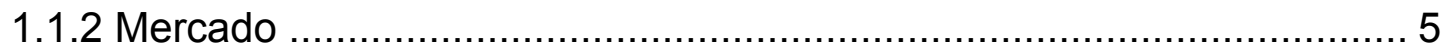

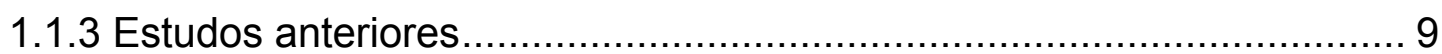

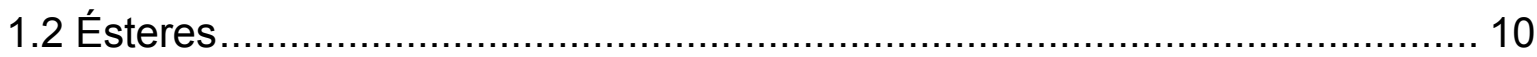

1.2.1 Definição e origem dos ésteres nas bebidas ................................... 10

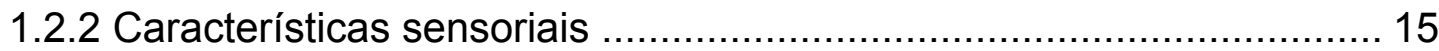

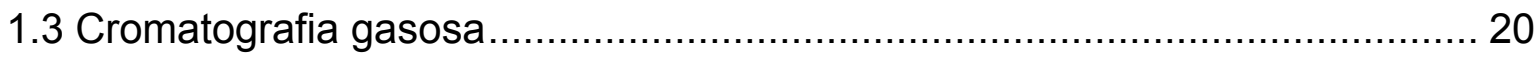

1.4 Cromatografia gasosa hifenada à espectrometria de massas .................... 22

1.5 Análise Multivariada .................................................................... 26

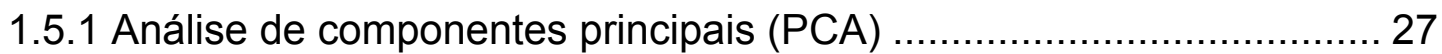

1.5.2 Regressão por mínimos quadrados parciais (PLS) …................... 27

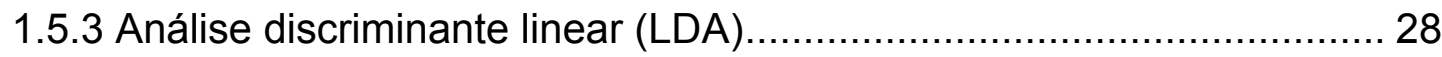

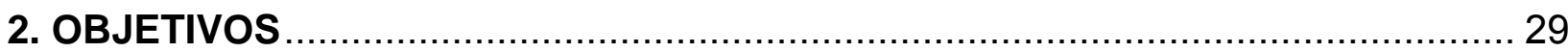




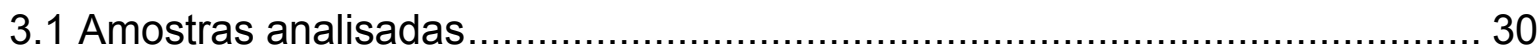

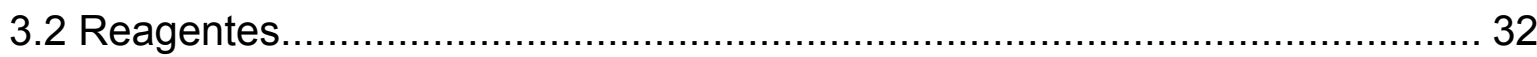

3.3 Procedimento empregado para a análise dos ésteres............................. 32

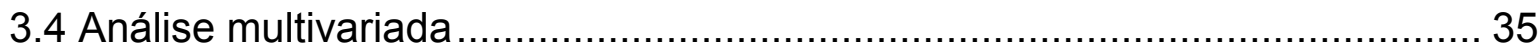

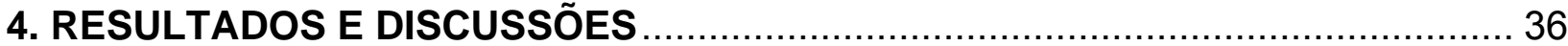

4.1 Concentrações dos ésteres nas amostras de aguardente de cana ..............44

4.1.1 A influência do sistema de destilação sobre o perfil de ésteres do

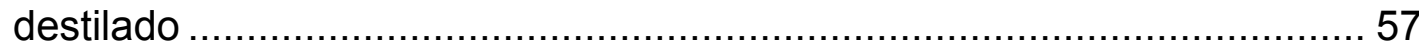

4.1.2 Análise multivariada .......................................................... 63

4.1.2.1 Análise de componentes principais ................................ 63

4.1.2.2 Regressão por mínimos quadrados parciais .......................69

4.1.2.3 Análise discriminante linear ......................................... 71

4.1.2.4 Sobre a presença dos compostos considerados na separação das amostras submetidas a diferentes processos de

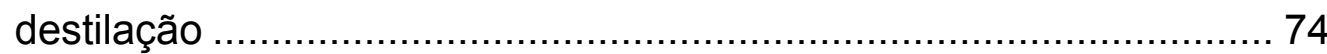

4.2 Concentrações dos ésteres nas amostras de cachaça comercial ................. 79

4.3 Concentrações dos ésteres nas amostras de rum e uísque comercial ........... 87

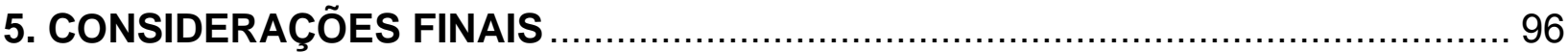

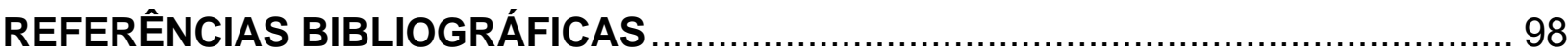




\section{LISTA DE FIGURAS}

Figura 1. Mercado de bebidas no Brasil 6

Figura 2. Percentual da produção nacional de cachaça de acordo com os estados produtores 8

Figura 3. Maiores empresas fabricantes/envasadoras de cachaça do Brasil 8

Figura 4. Quadro da formação de alguns componentes secundários durante a fermentação alcoólica 12

Figura 5. Esquema de formação dos ésteres a partir dos ácidos graxos alifáticos 14

Figura 6. Roda dos aromas 18

Figura 7. Esquema e componentes básicos de um cromatógrafo à gás: (1) Cilindro do gás de arraste; (2) Regulador de pressão de duplo estágio; (3) Válvula de controle do fluxo; (4) Injetor; (5) Seringa de injeção; (6) Forno; (7) Coluna; (8) Detector; (9) Registrador.

Figura 8. Diagrama esquemático de um detector de massas; (1) Moléculas provenientes do cromatógrafo à gas, (2) lonizador (impacto de elétrons), (3) ĺons, (4) Analisador de íons (quadrupolo), (5) Íon provenientes do quadrupolo (6) Detector (multiplicadora de elétrons)

Figura 9. Espectro de massas por impacto de elétrons do acetato de etila 24

Figura 10. Rota de fragmentação do acetato de etila 24

Figura 11. Cromatograma dos padrões de ésteres analisados no modo SIM. 1 acetato de etila, 2 butanoato de etila, 3 hexanoato de etila, 4 lactato de etila, 5 octanoato de etila, 6 nonanoato de etila, 7 decanoato de etila, 8 octanoato de isoamila, 9 dodecanoato de etila e PI 4-metil 2-pentanol 36 
Figura 12. Espectros de massas dos ésteres analisados obtidos no modo SCAN 38

Figura 13. Rearranjo de Mclafferty 40

Figura 14. Mecanismo da migração dupla do átomo de hidrogênio e formação do íon $75 \mathrm{~m} / \mathrm{z}$

Figura 15. Cromatograma de uma amostra analisada no SCAN. 1 acetato de etila, 2 butanoato de etila, 3 hexanoato de etila, 4 lactato de etila, 5 octanoato de etila, 7 decanoato de etila, 9 dodecanoato de etila....

Figura 16. Cromatograma de uma amostra analisada no SIM. 1 acetato de etila, 2 butanoato de etila, 3 hexanoato de etila, 4 lactato de etila, 5 octanoato de etila, 7 decanoato de etila, 8 octanoato de isoamila, 9 dodecanoato de etila

Figura 17. Relação entre a concentração de acetaldeído e a concentração de lactato de etila nas amostras de aguardente de cana.

Figura 18. Relação entre a concentração de acetato de etila e a concentração de lactato de etila nas amostras de aguardente de cana.

Figura 19. Histograma da mediana da concentração de cada analito de acordo com o sistema de destilação utilizado para as amostras de aguardente de cana. 1 acetato de etila, 2 butanoato de etila, 3 hexanoato de etila, 4 lactato de etila, 5 octanoato de etila, 6 nonanoato de etila, 7 decanoato de etila, 8 octanoato de isoamila, 9 dodecanoato de etila.

Figura 20. Histograma da mediana da concentração de cada analito de acordo com o sistema de destilação utilizado para as amostras de aguardente de cana. 1 butanoato de etila, 2 hexanoato de etila, 3 octanoato de etila, 4 nonanoato de etila, 5 decanoato de etila, 6 octanoato de isoamila e 7 dodecanoato de etila

Figura 21. Histograma da mediana da concentração total de ésteres para as amostras de aguardente de cana de acordo com o sistema de destilação utilizado.....62

Figura 22. Gráfico de pontuação obtido para as 136 amostras de aguardente de cana utilizando os ésteres como discriminantes 
Figura 23. Gráfico de pesos obtido para as 136 amostras de aguardente de cana utilizando os ésteres como discriminantes

Figura 24. Gráfico de pontuação obtido para as 82 amostras de aguardente de cana utilizando o novo banco de dados (107 amostras)

Figura 25. Gráfico de pesos obtido para as 82 amostras de aguardente de cana utilizando o novo banco de dados (107 amostras)

Figura 26. Gráfico de pontuação entre as componentes 1 e 2 da PLS

Figura 27. Gráfico de pesos das componentes 1 e 2 da PLS

Figura 28. Concentração de carbamato de etila nas aguardentes de cana destiladas em alambiques de cobre e colunas de aço inox.

Figura 29. Concentração de benzaldeído nas aguardentes de cana destiladas em alambiques de cobre e colunas de aço inox

Figura 30. Concentração de decanoato de etila nas aguardentes de cana destiladas em alambiques de cobre e colunas de aço inox.

Figura 31. Concentração de dodecanoato de etila nas aguardentes de cana destiladas em alambiques de cobre e colunas de aço inox

Figura 32. Histograma da mediana da concentração total de ésteres das amostras de cachaça comercial de acordo com o sistema de destilação utilizado.

Figura 33. Histograma da mediana da concentração total de ésteres das amostras de cachaça comercial de acordo com o tempo de envelhecimento

Figura 34. Concentração total de ésteres em amostras de rum branco e rum envelhecido. 1- Havana Silver/Havana 7 anos 2- Montilla Cristal/Montilla Ouro 3Bacardi Branca/Bacardi Oro.

Figura 35. Concentração relativa de acetato de etila na concentração total de ésteres 
Figura 36. Histograma da mediana da concentração de cada analito nas amostras de cachaça, rum e uísque. 1 acetato de etila, 2 butanoato de etila, 3 hexanoato de etila, 4 lactato de etila, 5 octanoato de etila, 6 nonanoato de etila, 7 decanoato de etila, 8 octanoato de isoamila, 9 dodecanoato de etila 


\section{LISTA DE TABELAS}

Tabela 1: Limites estabelecidos pela legislação brasileira para a cachaça e pela legislação cubana para o rum

Tabela 2: Distribuição do número de marcas de cachaça de acordo com os estados brasileiros

Tabela 3: Algumas propriedades físicas e químicas dos ésteres estudados

Tabela 4: Ílons monitorados ( $\mathrm{m} / \mathrm{z}$ ) para análise de ésteres no modo SIM

Tabela 5: Valores para o limite de detecção, limite de quantificação e repetibilidade do método utilizado no CG-EM

Tabela 6: Valores para a média, mediana, valor máximo e valor mínimo de concentração para os ésteres nas amostras de aguardente de cana

Tabela 7: Concentrações dos ésteres nas amostras de aguardente de cana (mg 100 $\mathrm{mL}^{-1}$ álcool anidro)

Tabela 8: Amostras com teores de ésteres totais acima do permitido pela legislação brasileira

Tabela 9: Valores para a média, mediana, valor máximo, valor mínimo de concentração para as amostras de aguardente de cana destiladas em alambique de cobre

Tabela 10: Valores para a média, mediana, valor máximo e valor mínimo de concentração para as amostras de aguardente de cana destiladas em alambique misto

Tabela 11: Valores para a média, mediana, valor máximo e valor mínimo de concentração para as amostras de aguardente de cana destiladas em coluna de aço inox. 
Tabela 12: Valores de pesos para cada discriminante químico obtidos na separação PC 1 x PC 2 .

Tabela 13: Classificação das amostras no modelo da LDA

Tabela 14: Classificação das amostras após a validação cruzada no modelo da LDA 73

Tabela 15: Valores para a média, mediana, valor máximo e valor mínimo da concentração para as amostras de cachaça.

Tabela 16: Concentrações dos ésteres nas amostras de cachaça comercial (mg $100 \mathrm{~mL}^{-1}$ de álcool anidro)

Tabela 17: Concentrações relativas dos ésteres nas amostras de aguardente de cana e cachaça comercial

Tabela 18: Valores de concentração de ésteres totais, graduação alcoólica e sistema de destilação utilizado para as amostras de cachaça comercial.

Tabela 19: Valores para a média, mediana, valor máximo e valor mínimo da concentração para as amostras de rum comercial

Tabela 20: Valores para a média, mediana, valor máximo e valor mínimo da concentração para as amostras de uísque comercial

Tabela 21: Concentrações dos ésteres nas amostras de rum comercial $\left(\mathrm{mg} 100 \mathrm{~mL}^{-1}\right.$ de álcool anidro).

Tabela 22: Concentrações dos ésteres nas amostras de uísque comercial (mg $100 \mathrm{~mL}^{-1}$ de álcool anidro)

Tabela 23: Valores de concentração de ésteres totais e graduação alcoólica para as amostras de rum e uísque comercial 


\section{LISTA DE ANEXOS}

ANEXO A - Concentração de álcool isoamílico, acetaldeído, carbamato de etila, benzaldeído e teor alcoólico das amostras de aguardente de cana analisadas 104

ANEXO B - Metodologia sugerida pelo Ministério da Agricultura, Pecuária e Abastecimento para a determinação de ésteres (ésteres etílicos - volumetria)

ANEXO C - Metodologia sugerida pelo Ministério da Agricultura, Pecuária e Abastecimento para a determinação de ésteres (acetato de etila - cromatografia gasosa)

ANEXO D - Metodologia sugerida pelo Ministério da Agricultura, Pecuária e Abastecimento para a determinação de ésteres (ésteres etílicos - cromatografia gasosa)

ANEXO E - Modelo do questionário entregue aos produtores de aguardente de cana no período de coleta das amostras

ANEXO F - Tipo do destilador das amostras de aguardente de cana

ANEXO G - Cachaças comerciais analisadas e cidades onde foram produzidas 


\section{RESUMO}

A presença de nove ésteres (acetato de etila, butanoato de etila, hexanoato de etila, lactato de etila, octanoato de etila, nonanoato de etila, decanoato de etila, octanoato de isoamila e dodecanoato de etila) foi investigada por cromatografia gasosa hifenada à espectrometria de massas via injeção direta de amostras (ID-CGEM). Cento e trinta e seis amostras de aguardente de cana foram coletadas durante sua destilação em diferentes produtores em diferentes cidades localizadas no interior do estado de São Paulo. Também foram analisadas 21 amostras de cachaça comercial, 10 amostras de rum e 10 amostras de uísque importados e obtidos em lojas "duty free shop".

A metodologia analítica desenvolvida para análise de ésteres demonstrou-se apropriada para a determinação destes compostos em bebidas destiladas, sendo simples (injeção direta), seletiva e relativamente rápida. Apresentou baixos limites de detecção e quantificação e boa repetibilidade.

O acetato de etila é o principal éster presente nas bebidas destiladas seguido pelo lactato de etila. Em todas as amostras de bebidas destiladas analisadas neste trabalho foi detectada a presença do éster lactato etila. A presença deste éster está relacionada com a contaminação do mosto por bactérias (Lactobacillus spp) responsáveis pela fermentação láctica. A concentração de lactato de etila nas amostras de cachaça e rum é muito superior à encontrada nas amostras de uísque.

A análise multivariada dos resultados analíticos aplicada ao banco de dados dos ésteres juntamente com as concentrações de carbamato de etila e benzaldeído levaram à formação de dois grupos bem distintos: amostras destiladas em 
alambiques de cobre e amostras destiladas em colunas de aço inox. Os modelos estatísticos gerados pelas análises exploratórias de PCA, PLS e LDA utilizando o carbamato de etila, benzaldeído, decanoato de etila e o dodecanoato de etila como discriminantes revelaram ser possíveis a diferenciação entre estes dois grupos de destilados com uma porcentagem de acerto de $81 \%$ para PCA, $78,4 \%$ para a PLS e $97,6 \%$ para LDA.

Os métodos cromatográficos sugeridos pelo Ministério da Agricultura, Pecuária e Abastecimento (MAPA) para a determinação de ésteres não englobam o monitoramento do lactato de etila, subestimando o resultado final. 


\section{ABSTRACT}

The presence of nine esters (ethyl acetate, ethyl butanoate, ethyl hexanoate, ethyl lactate, ethyl octanoate, ethyl nonanoate, ethyl decanoate, isoamyl octanoate, and ethyl dodecanoate) was investigated by gas chromatography hyphenated to a mass spectrometry through sample direct inject (DI-GC-MS). One hundred and thirty six sugar cane spirits collected immediately after its distillation from different producers and different cities located in the countryside of São Paulo state. Also, it was analyzed 21 commercial samples of cachaça, 10 samples of rum and 10 samples of whiskey imported and purchased from the duty free shop.

The analytical method applied to esters analysis was appropriated for the determination of these compounds in distilled spirits, since it is simple (direct inject), selective and reasonably fast. It presented low detection and quantification limits and good reproducibility.

Ethyl acetate is the main ester present in the distilled spirits followed by ethyl lactate. Ethyl lactate was detected in all the distilled beverage samples analyzed herein. The occurrence of this ester is related to bacterial contamination of must (Lactobacillus spp) responsible for the lactic fermentation. The ethyl lactate content in cachaça and rum samples are superior that presented by whiskey samples.

The multivariate analysis of the analytical results applied to the esters data set jointly with the content of ethyl carbamate and benzaldehyde lead to the clustering of two quite distinct groups: sugar cane spirits distilled in copper alembic and sugar cane spirits distilled in stainless steel column. The resulting statistical model generated by PCA, PLS and LDA exploratory analysis employing ethyl carbamate, 
benzaldehyde, ethyl decanoate, and ethyl dodecanoate as discriminators was able to distinguish between these two groups with a accuracy of $81 \%$ for PCA, $78,4 \%$ for PLS and $97,6 \%$ for LDA.

The chromatographic method recommended by the Ministério da Agricultura, Pecuária e Abastecimento (MAPA) for the esters determination does not include the monitoring of ethyl lactate leading to a underestimating of the final result. 


\section{INTRODUÇÃO}

\subsection{Aguardente}

\subsubsection{Regulamentações da aguardente de cana brasileira}

De acordo com a legislação brasileira, aguardente de cana é a bebida com graduação alcoólica entre $38 \%$ e $54 \%$ v/v à $20^{\circ} \mathrm{C}$ (vinte graus Celsius) obtida do destilado alcoólico simples de cana-de-açúcar ou pela destilação do mosto fermentado do caldo de cana-de-açúcar podendo ser adicionada de açúcares em até $6 \mathrm{~g} \mathrm{~L}^{-1}$, expressos em sacarose ${ }^{1}$.

Cachaça é a denominação típica e exclusiva da aguardente de cana produzida no Brasil, com graduação alcoólica entre $38 \%$ e $48 \%$ v/v à $20^{\circ} \mathrm{C}$ (vinte graus Celsius), obtida pela destilação do mosto fermentado do caldo de cana-deaçúcar, com características sensoriais peculiares, podendo ser adicionada de açúcares em até $6 \mathrm{~g} \mathrm{~L}^{-1}$, expressos em sacarose ${ }^{1}$.

O coeficiente de congêneres, também conhecido como componentes secundários, não pode ser inferior a $200 \mathrm{mg}$ ou superior a $650 \mathrm{mg}$ por $100 \mathrm{~mL}$ de álcool anidro. A aguardente de cana não pode conter mais que $200 \mathrm{mg}$ de ésteres totais (expressos em acetato de etila) para cada $100 \mathrm{~mL}$ de álcool anidro e íons de cobre em quantidade não superior a $5 \mathrm{mg} \mathrm{L}^{-1}$ (Tabela 1). Para efeito de comparação 
foram citados na Tabela 1 os limites estabelecidos pela legislação cubana ${ }^{2}$ para o rum. 
Tabela 1: Limites estabelecidos pela legislação brasileira para a cachaça e pela legislação cubana para o rum.

\begin{tabular}{|c|c|c|c|c|c|}
\hline \multirow{2}{*}{ Compostos } & \multirow{2}{*}{ Unidade } & \multicolumn{2}{|c|}{ Rum $^{a}$} & \multicolumn{2}{|c|}{ Aguardente de cana $^{b}$} \\
\hline & & Mínimo & Máximo & Mínimo & Máximo \\
\hline Cobre & $\mathrm{mg} \mathrm{L}^{-1}$ & \multicolumn{2}{|c|}{-} & - & 5,0 \\
\hline Chumbo & $\mathrm{mg} \mathrm{L}^{-1}$ & \multicolumn{2}{|c|}{-} & - & 0,20 \\
\hline Acidez volátil (em ácido acético) & mg $100 \mathrm{~mL}^{-1}$ A.A. & 100 & 300 & - & 150 \\
\hline Aldeídos totais (em aldeído acético) & mg $100 \mathrm{~mL}^{-1}$ A.A. & \multicolumn{2}{|c|}{-} & - & 30 \\
\hline Álcoois superiores & mg $100 \mathrm{~mL}^{-1}$ A.A. & 1750 & 3500 & \multicolumn{2}{|c|}{-} \\
\hline Soma Furfural + HMF* & mg $100 \mathrm{~mL}^{-1}$ A.A. & \multicolumn{2}{|c|}{-} & - & 5,0 \\
\hline Metanol & mg $100 \mathrm{~mL}^{-1}$ A.A. & \multicolumn{2}{|c|}{-} & - & 20 \\
\hline Carbamato de Etila & $\mathrm{mg} \mathrm{L}^{-1}$ & \multicolumn{2}{|c|}{-} & - & 0,15 \\
\hline Acroleína & mg $100 \mathrm{~mL}^{-1}$ A.A. & \multicolumn{2}{|c|}{-} & - & 5,0 \\
\hline 2-butanol (sec-butílico) & mg $100 \mathrm{~mL}^{-1}$ A.A. & \multicolumn{2}{|c|}{ - } & - & 10 \\
\hline 1-butanol (n-butílico) & mg $100 \mathrm{~mL}^{-1}$ A.A. & \multicolumn{2}{|c|}{ - } & - & 3,0 \\
\hline Teor de Açúcar & $g^{-1}$ & \multicolumn{2}{|c|}{ - } & \multicolumn{2}{|c|}{$6-30$} \\
\hline Dureza Total $^{* * * *}$ & mg $100 \mathrm{~mL}^{-1}$ A.A. & \multicolumn{2}{|c|}{-} & - & 150 \\
\hline
\end{tabular}


Tabela 1: Continuação.

A.A. = Álcool anidro

$a=$ Ministério de la Industria Alimentícia. Resolucion n 135/01, de 13/03/2001.

$\mathrm{b}=$ Ministério da Agricultura Pecuária e Abastecimento - Instrução Normativa n 13, de 29/06/2005

* Hidroximetilfurfural.

** Soma dos ácidos, aldeídos, ésteres, furfural e álcoois superiores.

*** Álcoois isobutílico, isoamílicos (2-metil-1butanol + 3-metil-1-butanol) e n-propílico.

**** Teor máximo em carbonato de cálcio. 
A legislação cubana estabelece apenas os limites para o teor de acidez (expresso em ácido acético), ésteres (expresso em acetato de etila) e álcoois superiores. O teor de ésteres totais no rum pode variar de 200 a $500 \mathrm{mg} 100 \mathrm{~mL}^{-1}$ de álcool anidro enquanto que na cachaça o teor de ésteres totais não pode superar o

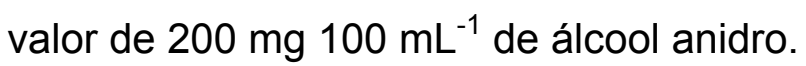

Considerando a necessidade de melhorar a qualidade da cachaça e a crescente demanda do produto no mercado internacional o INMETRO (Instituto Nacional de Metrologia, Normalização e Qualidade Industrial) através da portaria $\mathrm{n}^{\circ} 126$, de 24 de junho de $2005^{3}$, regulamentou o programa de certificação da cachaça. Este regulamento é de caráter voluntário e estabelece procedimentos para a certificação da cachaça garantindo um nível adequado de confiança, quanto à conformidade do produto em relação às normas e regulamentos aplicáveis.

A próxima iniciativa do INMETRO será a criação de um "selo de qualidade" para a cachaça que será associado à origem da bebida e deverá ter o selo do Instituto como pré-requisito ${ }^{4}$.

\subsubsection{Mercado}

A aguardente de cana-de-açúcar é a segunda bebida alcoólica mais consumida no Brasil, somente perdendo para a cerveja (Figura 1), com uma produção anual estimada em cerca de um bilhão e trezentos milhões de litros, ou seja, cerca de sete litros per capita ${ }^{\text {5,6. }}$.

\footnotetext{
${ }^{a}$ Calculado com base nos índices estatísticos e demográficos do IBGE (população de 186770562 em 2006)
} 


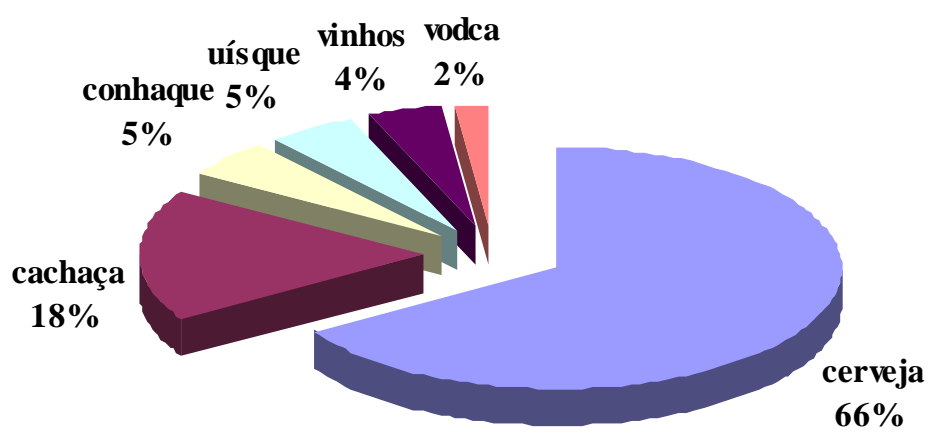

Figura 1. Mercado de bebidas no Brasil ${ }^{5}$.

Atualmente, o Brasil conta com mais de cinco mil marcas de cachaça, cerca de trinta mil produtores disseminados por todo o seu território, gerando aproximadamente de quatrocentos a quinhentos mil empregos diretos e indiretos e uma receita próxima de mais de seiscentos milhões de dólares ao ano ${ }^{5}$.

Minas Gerais é apontado como o estado com o maior número de cidades produtoras desta bebida que tanto agrada ao paladar dos brasileiros. O estado de Minas Gerais representa $74 \%$ das marcas de cachaça que somadas com as do estado de São Paulo totalizam $86 \%$ (Tabela 2). Os $14 \%$ restantes estão distribuídos nos demais estados da nação. Estes números mostram a grande vocação do estado de Minas Gerais na produção de cachaça ${ }^{7}$. 
Tabela 2: Distribuição do número de marcas de cachaça de acordo com os estados brasileiros.

\begin{tabular}{ccc}
\hline Estado & $\mathbf{N}^{\circ}$. Marcas de cachaça & $\%$ \\
\hline Minas Gerais & 266 & 74 \\
São Paulo & 50 & \\
Rio de Janeiro & 8 & \\
Pernambuco & 7 & \\
Paraná & 4 & \\
Rio Grande do Sul & 4 & \\
Paraíba & 3 \\
Bahia & 2 \\
Ceará & 2 \\
Espírito Santo & 2 \\
Goiás & 2 & \\
Pará & 2 & \\
Santa Catarina & 2 \\
Sergipe & 2 \\
Alagoas & 1 \\
\hline
\end{tabular}

Apesar do estado de Minas Gerais ser o estado com o maior número de cidades produtoras e o mais lembrado quando o assunto é cachaça, o estado de São Paulo se destaca como o maior produtor. O estado de São Paulo responde pela produção de $44,2 \%$ da oferta total, com o faturamento anual estimado em $\mathrm{R} \$ 5$ bilhões. Em seguida está Pernambuco e Ceará com 12,1\% cada. O estado de Minas Gerais, Goiás e Rio de Janeiro respondem cada um, com 8,0 \% da produção total $^{5,8}$ (Figura 2). 


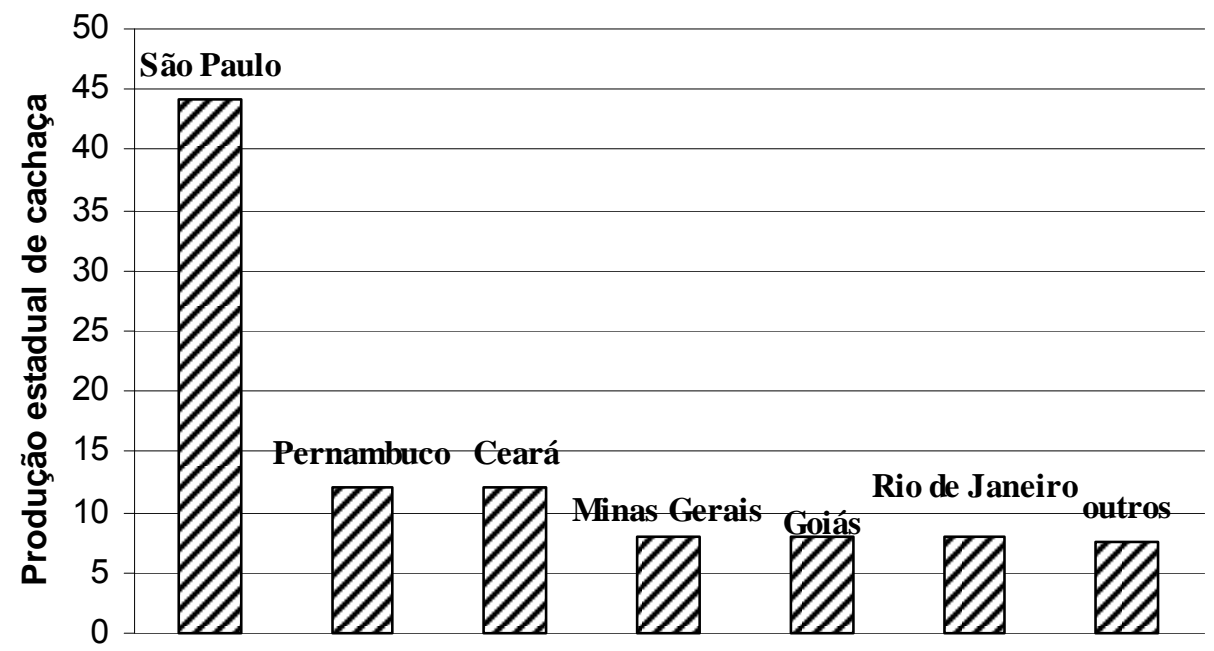

Figura 2. Percentual da produção nacional de cachaça de acordo com os estados produtores.

Atualmente, as empresas Pirassununga 51 (SP), Velho Barreiro (SP), Pitu (PE) e Ypióca (CE) são consideradas as maiores fabricantes/envasadoras de cachaça no Brasil, sendo que a Pirassununga 51 é responsável por um terço da produção do mercado ${ }^{8}$ (Figura 3).

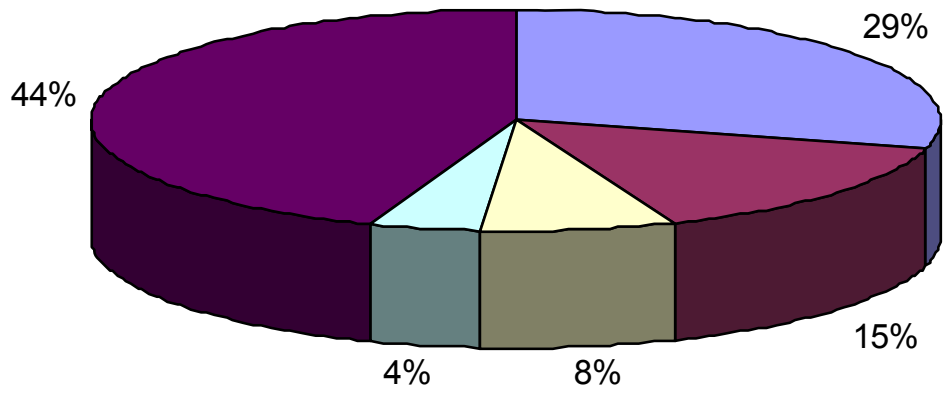

$\square$ Pirassununga $51 \square$ Pitu $\square$ Velho Barreiro $\square$ Ypióca $\square$ outros

Figura 3. Maiores empresas fabricantes/envasadoras de cachaça do Brasil. 
Apesar dos esforços do governo em promover a exportação da cachaça, o volume das exportações é ainda irrisório quando comparado ao total produzido. Em 2002, foram exportados 14,8 milhões de litros, o que representou pouco mais de $1 \%$ da produção total, gerando US\$ 8,5 milhões em divisas. Embora estes números estejam longe de um valor significativo desejado, o aumento do volume de exportações ano após ano é impressionante. Entre 1999 e 2002 houve um aumento de $247 \%$ no volume de exportações ${ }^{8}$.

Paraguai, Alemanha, Itália, Uruguai, Portugal, Bolívia, Estados Unidos e Chile são os países que mais importam cachaça, sendo que, Paraguai e Alemanha juntos respondem por cerca de metade das aquisições das exportações brasileiras ${ }^{8}$.

\subsubsection{Estudos anteriores}

A composição química da cachaça vem sendo estudada de forma sistemática há 13 anos pelo Laboratório para o Desenvolvimento da Química da Aguardente (LDQA) pertencente ao Instituto de Química de São Carlos (IQSC-USP). O LDQA vem propondo novas metodologias para a análise química rotineira de aguardente de cana e de outras bebidas destiladas, bem como se dedicando à compreensão da "química da cachaça".

Ao longo dos anos, vários estudos foram realizados com o intuito de se verificar os constituintes químicos presentes na cachaça brasileira, tais como: ácidos carboxílicos $^{9,10}$, álcoois e ésteres ${ }^{11,12}$, carbamato de etila ${ }^{13}$, aldeídos ${ }^{14}$, cetonas $^{15}$, compostos sulfurados $^{16}$, metais $^{17}$, compostos fenólicos ${ }^{18}$, aminoácidos $^{19}$ e 
hidrocarbonetos policíclicos aromáticos ${ }^{20}$, para um melhor conhecimento dos perfis químicos, mineral e orgânico, e as origens de compostos relacionados aos defeitos e às qualidades da cachaça ${ }^{21}$.

\section{2 Ésteres}

\subsubsection{Definição e origem dos ésteres nas bebidas}

Os ésteres são derivados dos ácidos carboxílicos onde o grupo $\mathrm{OH}$ é substituído por um grupo -OR e são geralmente substâncias de odores agradáveis e baixos limiares de percepção, que constituem importante fração de compostos orgânicos responsáveis pelo sabor e aroma de diversas frutas e flores. Os ésteres mais comuns entre os encontrados são: formato de etila (sabor artificial de rum), acetato de n-pentila (banana), acetato de octila (laranja), butirato de etila (abacaxi) e butirato de pentila (abricó). Os sabores artificiais de morango, cereja, maçã, dentre outros, são obtidos em grande parte da mistura de ésteres. Os sabores naturais, todavia, podem ser muito mais complexos: por exemplo, nada menos que 53 ésteres foram identificados entre os constituintes voláteis de uma determinada espécie de pêra ${ }^{22}$.

Os principais componentes da cachaça são: água e etanol. Assim como outros destilados, a cachaça é caracterizada organolepticamente pela presença de 
outros compostos, que representam menos que um por cento em massa de todos os componentes. Estes compostos secundários, tais como álcoois superiores, ésteres, ácidos carboxílicos e compostos carbonílicos são importantes para o aroma e sabor ("flavour") dos destilados $23,24,25$.

A principal origem dos ésteres, nas bebidas alcoólicas, está no metabolismo secundário intracelular das leveduras durante a fermentação alcoólica. A Figura 4 ilustra a formação de alguns congêneres provenientes do metabolismo secundário, entre eles os ésteres derivados dos álcoois superiores e os ésteres etílicos. 


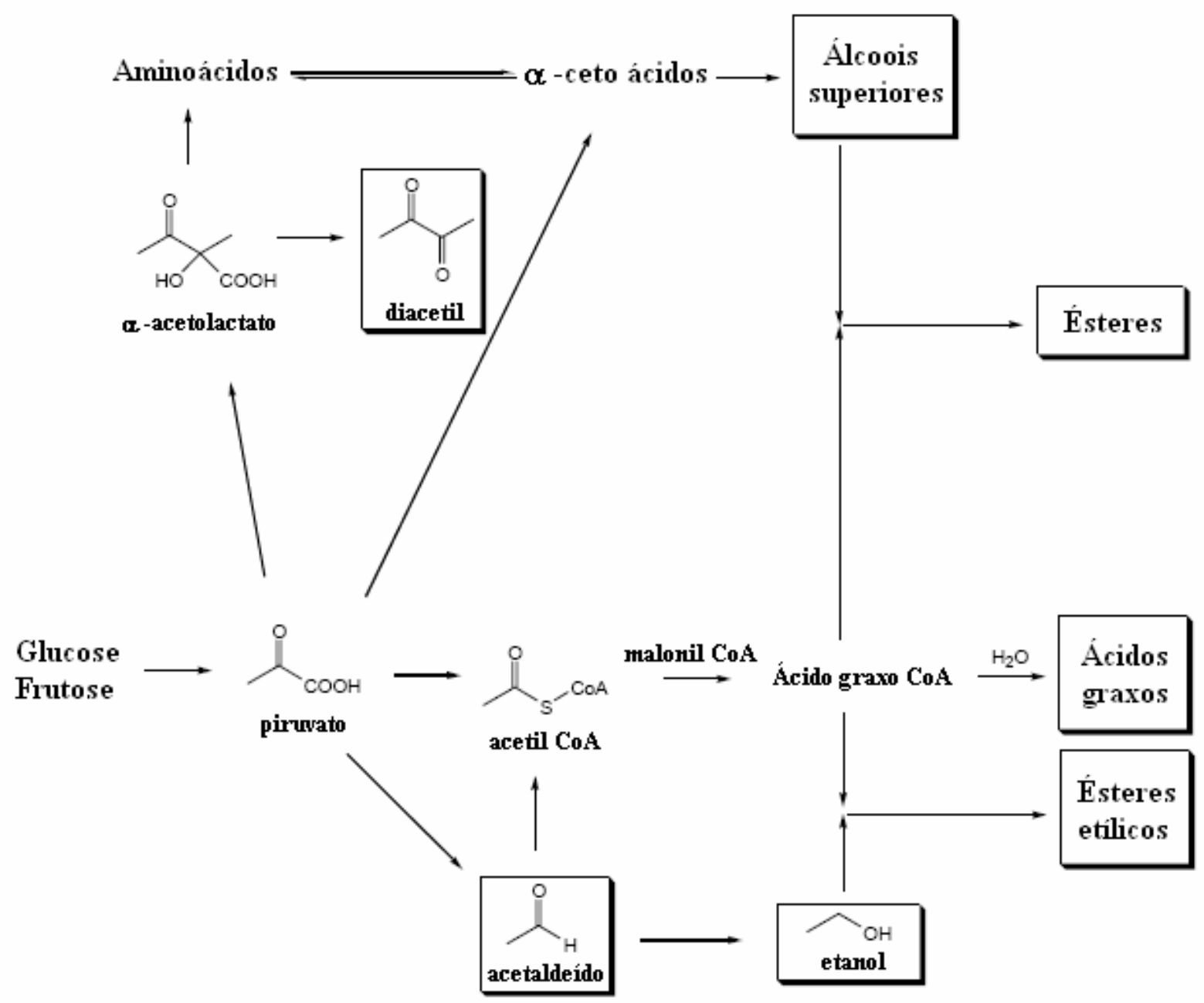

Figura 4. Quadro da formação de alguns componentes secundários durante a fermentação alcoólica.

A formação dos ésteres está basicamente relacionada com duas reações iniciais nas células das leveduras: a ativação de ácidos monocarboxílicos e a descarboxilação oxidativa dos ácidos 2-oxo. Adicionalmente a essas reações, um mecanismo muito provável é a formação de ésteres a partir dos intermediários da síntese dos ácidos monocarboxílicos de cadeia longa. A primeira fase da síntese dos ésteres é a formação do malonil-CoA. No complexo multienzimático o malonil-CoA se associa à acil-CoA, a qual foi formada no ciclo anterior, e transfere duas unidades 
de carbono à cadeia carbônica do ácido graxo. Após estas duas unidades de carbono serem transferidas para a acil-CoA, a etapa seguinte da reação dependerá do meio reacional. Na presença de água, quando a enzima é desligada do complexo multienzimático forma-se um ácido carboxílico. Entretanto, quando o rompimento se dá na presença de álcool, um éster é gerado. Esta proposta de mecanismo corrobora com o fato de que entre os ésteres formados pelas leveduras, são majoritários aqueles com o mesmo número de átomos de carbono no fragmento ácido da estrutura. Portanto, a formação de ésteres deve ser muito similar ao proposto para formação de ácidos graxos ${ }^{26}$ (Figura 5). 
Ativação de ácidos monocarboxílicos:

$\mathrm{R}-\mathrm{COOH}+\mathrm{ATP}+\mathrm{CoA} \sim \mathrm{SH} \longrightarrow \mathrm{R}-\mathrm{CO} \sim \mathrm{SCoA}+\mathrm{AMP}+\mathrm{PP}_{\mathrm{i}}+\mathrm{H}_{2} \mathrm{O}$

\section{Descarboxilação oxidativa:}

$\mathrm{R}-\mathrm{COCOOH}+\mathrm{NAD}+\mathrm{CoA} \sim \mathrm{SH} \longrightarrow \mathrm{R}-\mathrm{CO} \sim \mathrm{SCOA}+\mathrm{NADH}_{2}+\mathrm{CO}_{2}$

A partir dos intermediários da síntese dos ácidos monocarboxílicos de cadeia longa:

(a) $\mathrm{H}_{3} \mathrm{C}-\mathrm{CO} \sim \mathrm{SCOA} \stackrel{\mathrm{Mn}^{+2} \text { biotina } \mathrm{CO}_{2}}{\longrightarrow}-\mathrm{OOC}-\mathrm{H}_{2} \mathrm{C}-\mathrm{CO} \sim \mathrm{SCOA}$

(b) $\mathrm{R}-\mathrm{CO} \sim \mathrm{SCoA}+{ }^{-} \mathrm{OOC}-\mathrm{H}_{2} \mathrm{C}-\mathrm{CO} \sim \mathrm{SCoA} \longrightarrow \mathrm{R}-\mathrm{CH}_{2}-\mathrm{CH}_{2}-\mathrm{CO} \sim \mathrm{SCoA}+\mathrm{CoA} \sim \mathrm{SH}$

$$
+2 \mathrm{NADH}_{2}+2 \mathrm{NAD}+\mathrm{CO}_{2}+\mathrm{H}_{2} \mathrm{O}
$$

Os ésteres são formados pela alcoólise da acetil CoA:

$\mathrm{R}-\mathrm{CO} \sim \mathrm{SCOA}+\mathrm{R}^{\prime} \mathrm{OH} \longrightarrow \mathrm{R}-\mathrm{COOR}{ }^{\prime}+\mathrm{CoA} \sim \mathrm{SH}$

Figura 5. Esquema de formação dos ésteres a partir dos ácidos graxos alifáticos (adaptado da referência 26).

A concentração final de ésteres produzidos é dependente da abundância relativa dos álcoois e acil-CoAs correspondentes produzidos pela levedura. Uma vez que a acetil-CoA e o etanol são o ácido e o álcool mais abundantes presentes na fermentação, o acetato de etila é normalmente o éster presente em maior teor ${ }^{27}$.

A formação dos ésteres pós-fermentação alcoólica, via reação química direta entre álcoois e ácidos, também ocorre, porém em escala bem menor do que a via enzimática. Assim, durante o processo de envelhecimento da bebida ocorre a formação de ésteres, porém mais lentamente e em menor extensão ${ }^{26}$. 


\subsubsection{Características sensoriais}

Os ésteres derivados dos ácidos carboxílicos de cadeia curta e dos álcoois alifáticos possuem importância significativa no odor das bebidas destiladas. $\mathrm{O}$ acetato de etila é o éster predominante seguido pelos ésteres etílicos, isobutílicos e 3-metilbutílicos derivados dos ácidos graxos de baixa massa molecular. Também estão presentes os ésteres etílicos derivados dos ácidos graxos de alta massa molecular tais como o ácido caprílico, cáprico e láurico e, no uísque escocês, o ácido palmítico. Os ésteres também estão presentes no rum e a concentração total de ésteres expressos em termos de acetato de etila nos rums Jamaicanos varia de 80 a $1600 \mathrm{mg} 100 \mathrm{~m} \mathrm{~L}^{-1}$ de álcool anidro ${ }^{28}$.

Os ésteres são quali e quantitativamente (> $\left.100 \mathrm{mg} \mathrm{L}^{-1}\right)$ os constituintes majoritários dos vinhos junto com a água, o etanol e os álcoois fusel. Devido à suas concentrações, os ésteres etílicos derivados dos ácidos graxos são os compostos presentes em maior concentração seguidos pelos acetatos. Os ésteres etílicos de ácidos graxos e os acetatos são considerados importantes contribuintes do aroma do vinho. A eles é creditada a sensação de odores frutados semelhante àqueles freqüentemente utilizados como descritores do vinho. No entanto, sabe-se que o acetato de etila não contribui com o odor em concentrações abaixo de $75 \mathrm{mg} \mathrm{L}^{-1} \mathrm{e}$ quando presente em teores acima de $200 \mathrm{mg} \mathrm{L}^{-1}$ um efeito desagradável no aroma é observado $^{29}$

A Tabela 3 contém a relação dos ésteres escolhidos para serem identificados e quantificados nas amostras. Os ésteres foram escolhidos através de análises 
preliminares das amostras estudadas e com base nos dados da literatura. Estes são alguns dos ésteres de maior relevância em bebidas destiladas ${ }^{26,28,29,30,31,32}$. 
Tabela 3: Algumas propriedades físicas e químicas dos ésteres estudados ${ }^{33,34,35}$.

\begin{tabular}{|c|c|c|c|}
\hline NOME & $\begin{array}{c}\text { MASSA } \\
\text { MOLECULAR }\end{array}$ & $\begin{array}{c}\text { PONTO DE } \\
\left.\text { EBULIÇÃO ( }{ }^{\circ} \mathrm{C}\right)\end{array}$ & AROMA \\
\hline Acetato de etila & 88,12 & 77,06 & $\begin{array}{l}\text { Solvente; Frutado; } \\
\text { Abacaxi }\end{array}$ \\
\hline Butanoato de etila & 116,16 & 121 & $\begin{array}{l}\text { Maça; Banana; } \\
\text { Doce; Frutado; }\end{array}$ \\
\hline Hexanoato de etila & 144,22 & 168 & $\begin{array}{c}\text { Banana; Abacaxi; } \\
\text { Doce; Frutado; } \\
\text { Conhaque; Maçã } \\
\text { verde }\end{array}$ \\
\hline Lactato de etila & 118,13 & 151 & Frutado \\
\hline Octanoato de etila & 172,27 & 208,5 & $\begin{array}{c}\text { Frutado; Banana; } \\
\text { Abacaxi; } \\
\text { Damasco; Vinho; } \\
\text { Floral }\end{array}$ \\
\hline Nonanoato de etila & 186,30 & 227 & Frutado \\
\hline Decanoato de etila & 200,33 & 241,5 & $\begin{array}{c}\text { Maça; Conhaque; } \\
\text { Uva; Doce; } \\
\text { Frutado; Oleoso }\end{array}$ \\
\hline $\begin{array}{l}\text { Octanoato de } \\
\text { isoamila }\end{array}$ & 198,31 & 267 & Frutado; Floral \\
\hline $\begin{array}{c}\text { Dodecanoato de } \\
\text { etila }\end{array}$ & 228,38 & 269 & Frutado; Floral \\
\hline
\end{tabular}


Ésteres são compostos que se destacam na análise sensorial devido às suas características aromáticas. Os ésteres selecionados no presente estudo enquadramse principalmente na categoria dos aromas frutados, conforme se observa na Figura 6.

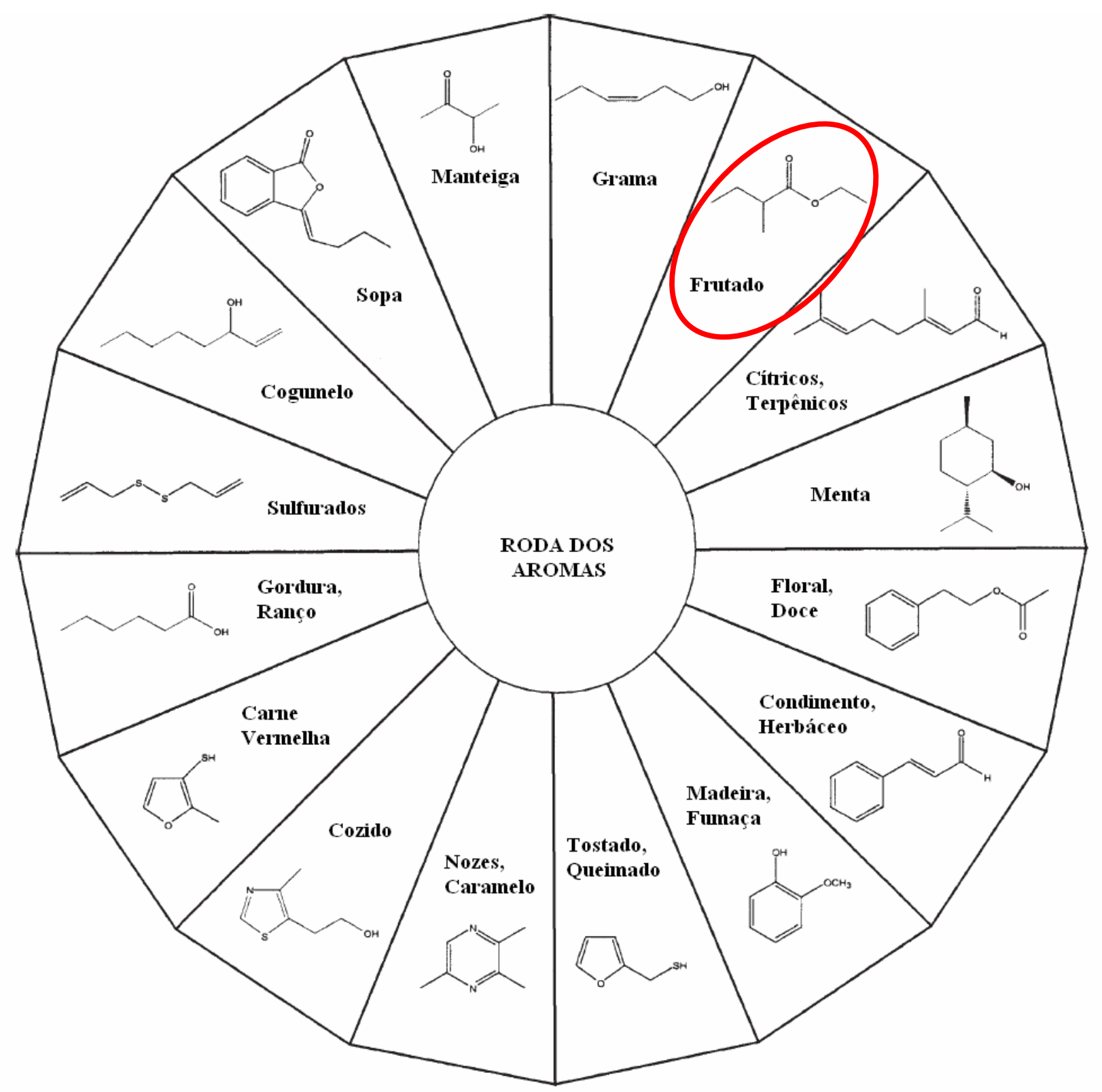

Figura 6. Roda dos aromas (adaptado da referência 36).

O valor de aroma, ou intensidade de aroma ("aroma value") é significativamente influenciado pela natureza de ambas as partes, álcool e ácido 
graxo. $O$ valor de aroma $A_{x}$ de um composto é calculado de acordo com a seguinte definição: $A_{x}=C_{x} / a_{x}$ onde $C_{x}$ : concentração do composto $X$ no bebida e $a_{x}$ : limiar de percepção de odor $^{\mathrm{b}}$ do composto $\mathrm{X}$ na bebida ${ }^{37}$. Em termos gerais observa-se 0 seguinte comportamento para ésteres alifáticos ${ }^{38}$ :

- Ésteres alifáticos com até oito carbonos são fortemente frutados.

- Ésteres de álcoois com seis a dez carbonos e ácidos com dois carbonos são moderadamente frutados.

- Ésteres de álcoois com seis a dez carbonos e ácidos com três a cinco carbonos são frutados.

- Ésteres de álcoois até dez carbonos e ácidos com mais de oito carbonos não são frutados.

- Ésteres de ácidos com três a cinco carbonos são mais frutados que ésteres com um a dois carbonos, que por sua vez, são mais frutados que ésteres de ácidos com mais de seis carbonos.

- Em geral, o grau de frutado (fruitness) diminui com o aumento da massa molecular.

\footnotetext{
${ }^{b}$ Limiar de percepção de odor é definido como a menor concentração de um composto que seja suficiente para o reconhecimento do seu odor.
} 


\subsection{Cromatografia gasosa}

Cromatografia gasosa é um método instrumental de separação no qual os componentes de uma amostra particionam-se em duas fases: uma dessas fases é uma fase estacionária com uma grande área superficial e a outra é um gás que percola através da fase estacionária. O equilíbrio de partição da amostra na fase líquida estacionária e na fase gasosa baseia-se na sua solubilidade e na temperatura da fase estacionária. Os componentes da amostra (chamados solutos ou analitos) separam-se um do outro baseado em suas pressões de vapor relativa e afinidades pela fase estacionária ${ }^{39}$.

As unidades fundamentais de um sistema cromatográfico são: gás de arraste, injetor, coluna, unidade de controle de temperatura (forno), detector e registrador, conforme mostra a Figura 7. Quando a válvula principal de regulador de pressão de duplo estágio do cilindro de gás de arraste é aberta, o gás flui em direção ao injetor. A amostra introduzida é vaporizada no injetor e carregada pelo gás de arraste através da coluna onde é então separada. A temperatura da coluna é controlada dentro de um forno. Os componentes isolados são detectados individualmente e o sinal do analito gerado é enviado para um sistema de registro de dados, usualmente um computador, o qual permitirá um cálculo da quantidade de cada componente originalmente presente na amostra ${ }^{40}$. 


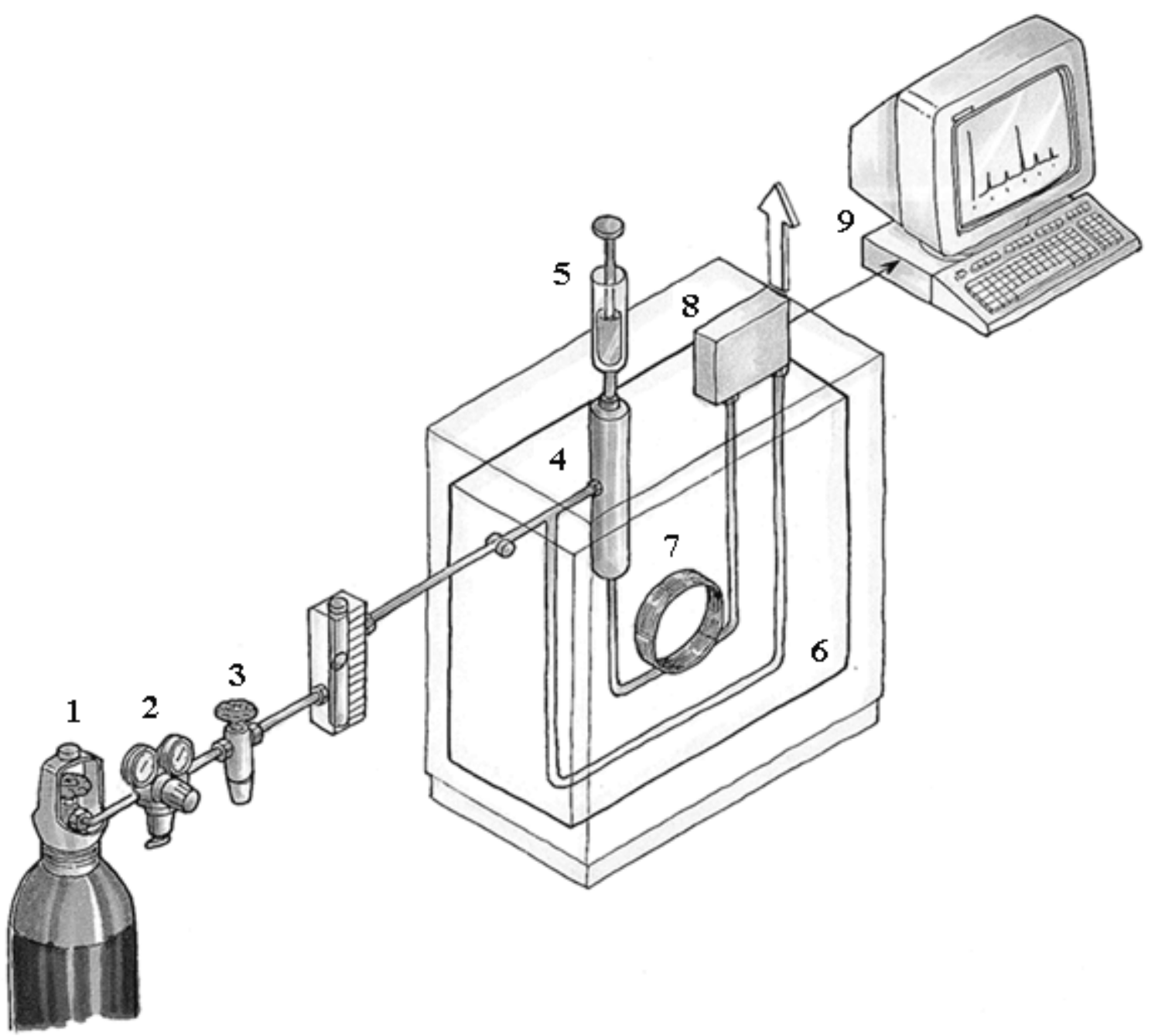

Figura 7. Esquema e componentes básicos de um cromatógrafo à gás: (1) Cilindro do gás de arraste; (2) Regulador de pressão de duplo estágio; (3) Válvula de controle do fluxo; (4) Injetor; (5) Seringa de injeção; (6) Forno; (7) Coluna; (8) Detector; (9) Registrador de dados (integrador).

A cromatografia gasosa só pode ser empregada na análise de substâncias voláteis e estáveis termicamente, caso contrário, há necessidade de se formar um derivado com estas características. Talvez o maior problema da cromatografia gasosa seja a falta de uma prova concreta da natureza dos compostos detectados. $\mathrm{Na}$ maioria dos detectores empregados nessa técnica (detector por ionização de chama (D.I.C.); detector por condutividade térmica (D.C.T.); detector por captura de elétrons (D.C.E.)) a identificação é baseada somente no tempo de retenção do 
analito na coluna. Partindo do princípio de que existe a possibilidade de mais de um composto apresentar o mesmo tempo de retenção, surgem então dúvidas com relação à natureza e pureza do(s) composto(s) no pico separado. Este inconveniente pode ser em grande parte contornado pela adição de padrões e utilizando-se colunas e detectores diferentes.

\subsection{Cromatografia gasosa hifenada à espectrometria de massas}

A espectrometria de massas é muito utilizada como detector cromatográfico, pois permite a obtenção de informações tanto qualitativas quanto quantitativas. O espectrômetro pode ser altamente seletivo ao analito de interesse. Esta seletividade facilita as exigências no preparo da amostra ou na necessidade da separação cromatográfica completa dos constituintes presentes em uma mistura e aumenta a razão sinal/ruído ${ }^{41}$.

O detector de massas mais simples utilizado na cromatografia gasosa é uma versão de baixa resolução de um espectrômetro de massas. Cada pico eluido da coluna cromatográfica é bombardeado com uma fonte ionizante (geralmente impacto por elétrons) capaz de fragmentar o composto gerando uma grande diversidade de íons. Os íons são separados em um analisador de massas (neste caso utiliza-se quatro barras denominadas quadrupolo, empregando radiofreqüência). A interação dos fragmentos iônicos com a radiofreqüência faz com que apenas íons de determinada relação massa/carga $(\mathrm{m} / \mathrm{z})$ passem intactos sem colidirem com as barras do quadrupolo e/ou as fendas de focalização. Variando-se a radiofreqüência, 
torna-se possível efetuar uma varredura através de ampla faixa do espectro de massas de interesse ${ }^{42}$.

A Figura 8 ilustra um diagrama esquemático de um detector de massas.

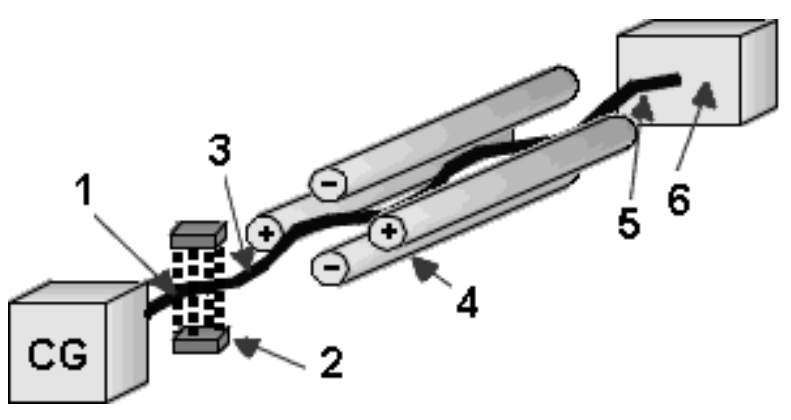

Figura 8. Diagrama esquemático de um detector de massas; (1) Moléculas provenientes do cromatógrafo à gás, (2) lonizador (impacto de elétrons), (3) ĺons, (4) Analisador de íons (quadrupolo), (5) Íons provenientes do quadrupolo (6) Detector (multiplicadora de elétrons).

$\mathrm{Na}$ técnica de ionização por impacto de elétrons (EI) comumente a mais usada em um espectrômetro de massas uma fonte bombardeia moléculas na fase vapor com um feixe de elétrons de alta energia e registra o resultado do impacto de elétrons como um espectro de íons separados na base da razão massa/carga. A maior parte dos íons formados tem carga unitária. A Figura 9 mostra o espectro de massas do acetato de etila como um gráfico de abundância produzido por computador (intensidade dos picos verticais) versus $\mathrm{m} / \mathrm{z}$. O pico do íon positivo em $\mathrm{m} / \mathrm{z} 88$ corresponde à molécula intacta $(\mathbf{M})$ com perda de um elétron, removido pelo feixe de energia, e é chamado íon molecular $\left(\mathbf{M}^{\bullet+}\right)^{43}$. 

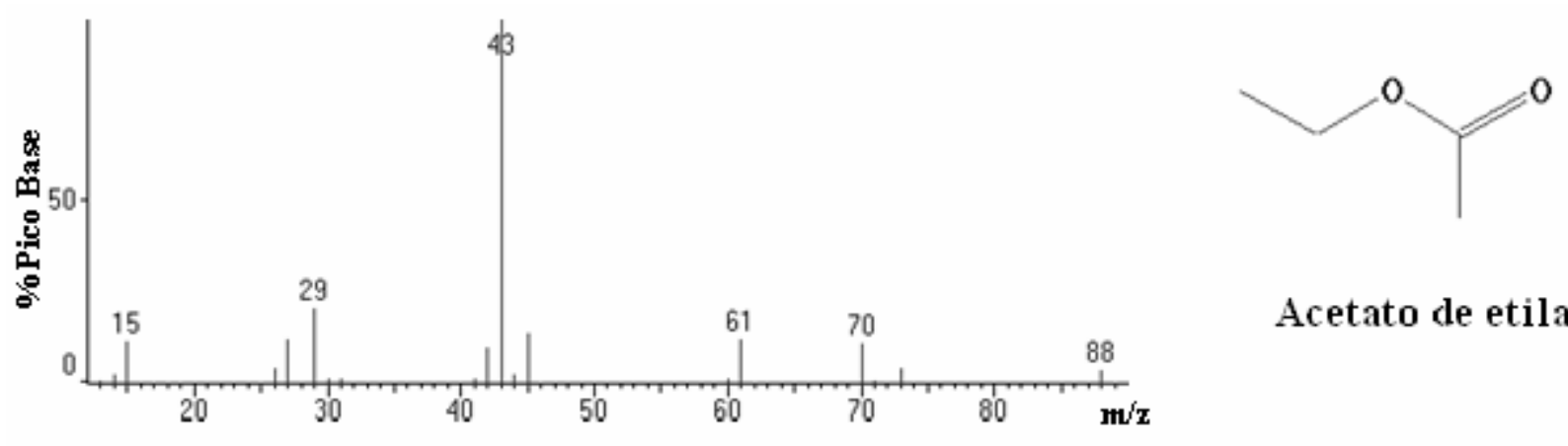

Acetato de etila

Figura 9. Espectro de massas por impacto de elétrons do acetato de etila.

O íon molecular $\left(\mathbf{M}^{\bullet+}\right)$, por sua vez, produz uma série de fragmentos ionizados, conforme mostra a Figura 10.

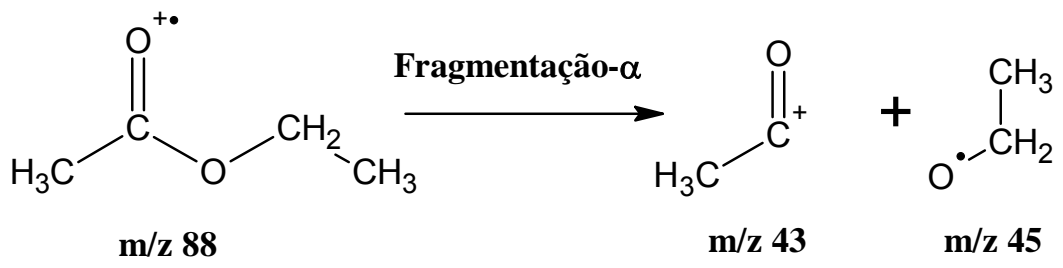

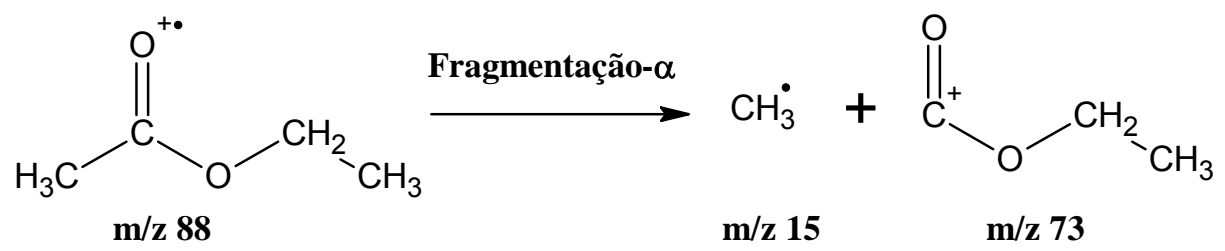

Figura 10. Rota de fragmentação do acetato de etila.

Os detectores de massa têm vários modos de apresentação de resultados, que os colocam em duas categorias: de tempo real e reconstituído por computador. Dentro de cada uma dessas categorias, há escolha dos cromatogramas de corrente iônica total, ou varredura de espectro (um gráfico da soma de todas as correntes iônicas em função do tempo) ou cromatogramas de corrente iônica selecionada, ou 
monitoramento seletivo de íons ${ }^{44}$ (um gráfico de correntes iônicas para um ou poucos íons em função do tempo).

O monitoramento seletivo de íons (SIM - Selected Ion Monitored) aumenta a seletividade da espectrometria de massas para determinados analitos e melhora a detectabilidade diminuindo a resposta do instrumento a tudo que interfira na medida (isto é, reduzindo o ruído de fundo). No SIM o espectrômetro de massas está ajustado para monitorar apenas alguns poucos valores de $\mathrm{m} / \mathrm{z}$ (geralmente não mais que quatro ou cinco em qualquer intervalo de tempo). O principal motivo pelo aumento da detectabilidade no SIM é que a maioria do tempo de aquisição espectral é gasto na aquisição de dados em uma faixa pequena de massa ${ }^{41}$.

A seleção dos íons no SIM é feita de acordo com o espectro de massas de cada analito e geralmente os íons escolhidos são aqueles que possuem maior intensidade (pico base) e que não tenham interferência com nenhum outro íon presente na amostra.

As vantagens mais relevantes dos detectores de massa são sua sensibilidade, seletividade e o fato de poderem fornecer informações estruturais a respeito dos compostos eluídos da coluna e sua principal limitação prática é seu custo elevado quando comparado aos detectores "clássicos" usados em cromatografia gasosa ${ }^{42}$. 


\subsection{Análise multivariada}

As técnicas de análise multivariada possibilitam avaliar um conjunto de características, levando em consideração as correlações existentes, o que permite que interferências sobre o conjunto de características sejam feitas em um nível de significância conhecido. A análise multivariada vem sendo empregada com bastante freqüência na química visando encontrar correlações entre os dados obtidos ${ }^{45,46,47}$. Dentre as diversas técnicas quimiométricas encontradas na literatura, as mais utilizadas são: Análise de Componentes Principais (PCA - Principal Components Analysis), Análise Hierárquica de Agrupamentos (HCA - Hierarchical Cluster Analysis), Análise de Fatores (FA - Factor Analysis), Regressão por Mínimos Quadrados Parciais (PLS - Partial Least Square), Análise Discriminante (DA Discriminant Analysis), Análise Discriminante Linear (LDA - Linear Discriminant Analysis), Análise Discriminante Quadrática (QDA - Quadratic Discriminant Analysis), Análise Discriminante Canônica (CDA - Canonical Discriminant Analysis), entre outras.

Neste trabalho foi realizada apenas uma análise exploratória do banco de dados dos resultados analíticos (PCA, PLS e LDA). O objetivo da análise exploratória é fazer uma avaliação inicial dos dados para descobrir que tipo de informação é possível extrair deles, e assim definir as diretrizes para um tratamento mais aprofundado. Isto é feito através da utilização de algoritmos que permitem reduzir a dimensão dos dados, ou organizá-los em uma estrutura que facilite a visualização de todo o conjunto, de forma global. 


\subsubsection{Análise de componentes principais (PCA)}

A PCA é um tratamento matemático que identifica no hiperespaço das variáveis as direções na qual a maior parte das informações está contida. Por meio da projeção dos resultados analíticos de cada amostra no espaço formado pelas novas componentes principais, é possível demonstrar diferenças entre as várias amostras, ou grupos de amostras (gráfico de pontuação), determinando ao mesmo tempo quais variáveis principais estão envolvidas ${ }^{48,49,50}$ (gráfico de pesos). A análise de componentes principais é uma técnica estatística poderosa que pode ser utilizada para redução do número de variáveis e para fornecer uma visão estatisticamente privilegiada do conjunto de dados.

\subsubsection{Regressão por mínimos quadrados parciais (PLS)}

A regressão por mínimos quadrados parciais e uma técnica de análise multivariada de dados utilizada para relacionar uma ou mais variáveis respostas $\mathbf{Y}$, com diversas variáveis independentes $\mathbf{X}$, baseada no uso de fatores ${ }^{51}$.

A PLS reduz o número de variáveis para um grupo de variáveis não correlacionadas e executa a regressão (mínimos quadrados) neste grupo de variáveis, ajustando múltiplas variáveis em um modelo único ${ }^{52}$.

O método dos mínimos quadrados parciais é particularmente utilizado quando as variáveis são altamente colineares ou quando possuímos mais variáveis do que 
amostras e a regressão normal falhou ou produziu coeficientes com alto desvio padrão ${ }^{53}$.

\subsubsection{Análise discriminante linear (LDA)}

A análise discriminante linear consiste em procurar uma função que permite distinguir os pontos relativos aos dados de duas categorias diferentes. Se existe tal função, diz-se que os pontos pertencentes às duas categorias são linearmente separáveis $^{49}$. A LDA é um tratamento estatístico que apresenta melhores resultados quando são considerados dois ou três grupos de amostras. Para uma quantidade maior de grupos esta análise torna-se ineficiente ${ }^{48}$. 


\section{OBJETIVOS}

Conhecer o perfil químico qualitativo e quantitativo dos ésteres da aguardente de cana paulista objetivando contribuir para o conhecimento da química da aguardente e sua tipificação. Para isso foram determinados nove ésteres em 136 amostras de aguardente de cana coletadas em diferentes cidades do interior do estado de São Paulo (in loco), utilizando a técnica de cromatografia gasosa hifenada à espectrometria de massas por injeção direta de amostra (ID-CG-EM). Foram também incluídas amostras de cachaça comercial que participaram do Concurso da Cachaça realizado na cidade de São José do Rio Preto no ano de 2006 e amostras de uísque comercial e de rum comercial.

Propõe-se verificar se há uma diferença no perfil químico de ésteres em amostras que foram submetidas a diferentes processos de destilação, alambique e coluna, uma vez que o sistema de destilação utilizado pelos produtores foi especificado durante o processo de coleta das amostras.

Comparar o perfil químico de ésteres das aguardentes de cana brasileiras com os perfis químicos de ésteres de outros destilados com a finalidade de obter um conhecimento dos teores relativos destes componentes. 


\section{PARTE EXPERIMENTAL}

\subsection{Amostras analisadas}

Neste trabalho foram analisadas 136 amostras de aguardente de cana coletadas de diferentes produtores e em diferentes cidades localizadas no interior do estado de São Paulo. Estas amostras foram coletadas imediatamente após a sua destilação, no próprio local de sua produção. Também foram analisadas 21 amostras de cachaça comercial que participaram do Concurso da Cachaça realizado no "VI Brazilian Meeting on Chemistry of Food and Beverage" que ocorreu de 30 de novembro a 03 de dezembro de 2006 na cidade de São José do Rio Preto-SP.

Para comparar o perfil químico de ésteres da aguardente de cana brasileira com o perfil químico de ésteres de outros destilados foram analisadas 10 amostras de rum e 10 amostras de uísque importados e obtidos em lojas "duty free shop".

Amostras de cachaça comercial: Volúpia( ${ }^{(D)}$, Campanari ${ }^{(D)}$, Chora Menina ${ }^{(E)}$, São Saruê ${ }^{(D)}$, Reserva do Gerente $^{(D)}$, Porão ${ }^{(E)}$, Caribeña Prata ${ }^{(D)}$, Caribeña Ouro ${ }^{(E)}$, Vale das Águas Quentes ${ }^{(E)}$, Elisa Prata ${ }^{(D)}$, Elisa Premium ${ }^{(E)}$, Tiquara $^{(E)}$, Aroma Brasil Castanheira $^{(\mathrm{D})}$, Aroma Brasil Jequitibá( ${ }^{(\mathrm{D})}$, Engenho da Vertente ${ }^{(\mathrm{E})}$, Reserva do Tanoeiro $^{(E)}$, Armazém Vieira Terra $^{(E)}$, Armazém Vieira Safira ${ }^{(E)}$, Souza Andrade/Fonseca $^{(E)}$, Cachaça Valle ${ }^{(E)}$, Valle-Souza Andrade/Fonseca ${ }^{(E)}$. Onde: (D): cachaça descansada; (E): cachaça envelhecida. 
A denominação cachaça descansada engloba as amostras de cachaça (definido no item 1.1.1) conforme estabelecido pelo Ministério da Agricultura, Pecuária e Abastecimento (MAPA) ${ }^{1}$ e as amostras de cachaça que foram estocadas em recipiente de madeira em um período inferior a um ano. A denominação cachaça envelhecida engloba as amostras de cachaça que contém no mínimo $50 \%$ de cachaça ou aguardente de cana envelhecidas em recipiente de madeira apropriado, com capacidade máxima de 700 litros, por um período não inferior a um ano, conforme estabelecido pelo MAPA ${ }^{1}$.

Amostras de rum: Havana Silver $\left(\right.$ Cubano) ${ }^{(B)}$, Havana 7 anos (Cubano) ${ }^{(E)}$, Montilla Cristal (Brasileiro) $)^{(\mathrm{B})}$, Montilla Ouro (Brasileiro $)^{(\mathrm{E})}$, Bacardi Carta Branca

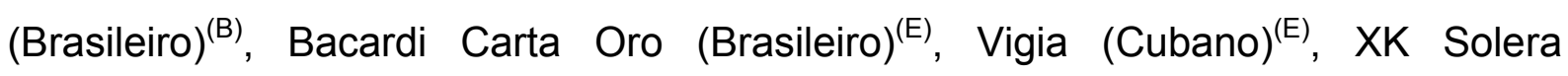

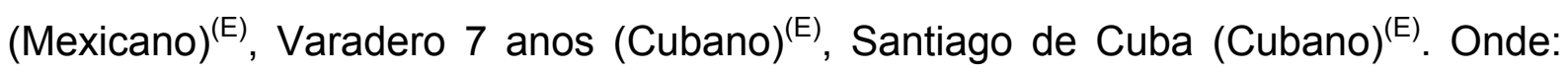
(B): rum branco, não envelhecido; (E): rum envelhecido.

Amostras de uísque: Johnnie Walker Black Label (Escocês) ${ }^{(12)}$, Johnnie Walker Gold Label (Escocês) ${ }^{(18)}$, Johnnie Walker Blue Label (Escocês) ${ }^{(21)}$, Johnnie Walker Green Label (Escocês) $)^{(15) s m}$, The Famous Grouse (Escocês) $)^{(8)}$, William Grant's (Escocês) ${ }^{(8)}$, Jameson (Irlandês) ${ }^{(8)}$, Maker's Mark (Norte-americano) ${ }^{(8)}$, Ballantine's Finest (Escocês) $^{(12)}$, Passport (Escocês) $)^{(8)}$. Onde: (8): 8 anos envelhecido (12): 12 anos envelhecido; (15)sm: 15 anos envelhecido, single malte; (18): 18 anos envelhecido; (21): 21 anos envelhecido. 


\subsection{Reagentes}

Todos os reagentes utilizados foram de grau de pureza analítico. Os padrões de acetato de etila, butanoato de etila, hexanoato de etila, lactato de etila, octanoato de etila, nonanoato de etila, decanoato de etila, octanoato de isoamila e dodecanoato de etila e o padrão interno 4-metil 2-pentanol foram obtidos da SigmaAldrich e utilizados sem prévio tratamento. Para o preparo da solução alcoólica (etanol/água) 40\% v/v foi utilizado álcool etílico grau HPLC (Fisher Scientific) e água destilada deionizada em sistema MilliQ (Millipore). O processo de obtenção do álcool etílico é semelhante ao da cachaça, assim os ésteres analisados também podem estar presentes no álcool etílico. O álcool etílico grau HPLC (Fisher Scientific) foi previamente analisado utilizando a mesma metodologia empregada para a análise dos ésteres e não apresentou nenhum interferente.

\subsection{Procedimento empregado para a análise dos ésteres}

As análises foram realizadas em um cromatógrafo Shimadzu GC-17A, equipado com um detector de massas Shimadzu QP5050A operando no modo de impacto eletrônico com 70 eV, com monitoramento de íon seletivo (SIM) (Tabela 4) e injeção direta da amostra. 
Tabela 4: ĺons monitorados (m/z) para análise de ésteres no modo SIM.

\begin{tabular}{|c|c|c|c|}
\hline Janelas & $\begin{array}{c}\text { Tempos de } \\
\text { aquisição (min.) }\end{array}$ & $\begin{array}{l}\text { Íons } \\
\text { (m/z) }\end{array}$ & Compostos \\
\hline 1 & $4,00-6,50$ & 70 & Acetato de etila \\
\hline 2 & $6,50-8,00$ & 88 & Butanoato de etila \\
\hline 3 & $8,00-11,40$ & 69 & 4-metil 2-pentanol \\
\hline 4 & $11,40-15,00$ & 88 & Hexanoato de etila \\
\hline 5 & $15,00-16,25$ & 75 & Lactato de etila \\
\hline \multirow{3}{*}{6} & \multirow{3}{*}{$16,25-22,70$} & \multirow{3}{*}{88} & Octanoato de etila \\
\hline & & & Nonanoato de etila \\
\hline & & & Decanoato de etila \\
\hline 7 & $22,70-25,00$ & 70 & Octanoato de isoamila \\
\hline 8 & $25,00-29,00$ & 88 & Dodecanoato de etila \\
\hline
\end{tabular}

A coluna cromatográfica empregada foi uma HP-FFAP $(50 \mathrm{~m} \times 0,20 \mathrm{~mm} \times$ 0,33 $\mu \mathrm{m}$ de espessura do filme da fase estacionária de polietileno glicol esterificado) e a seguinte programação de temperatura para o forno: temperatura inicial de $35^{\circ} \mathrm{C}$ elevada a $5^{\circ} \mathrm{C} \min ^{-1}$ até $180^{\circ} \mathrm{C}$, e então, elevada a $20^{\circ} \mathrm{C} \min ^{-1}$ até $220^{\circ} \mathrm{C}$ e mantida por 5 minutos. A temperatura do injetor e da interface do detector foi de $220^{\circ} \mathrm{C}$. 
O volume de injeção foi de 1,0 $\mu \mathrm{L}$ com um "split" de 1:15 utilizando hélio como gás de arraste com vazão de $1,0 \mathrm{~mL} \mathrm{~min}^{-1}$. As medidas foram efetuadas em triplicatas.

Para a análise quantitativa empregou-se o método da adição de padrão contendo um padrão interno (4-metil 2-pentanol) e para a análise qualitativa utilizouse, além do monitoramento dos íons selecionados (Tabela 4), o tempo de retenção. A confirmação foi realizada através da comparação entre o fragmentograma do padrão e do respectivo pico na amostra e pela adição da solução padrão de cada composto na amostra e subseqüente observação do aumento da área do pico, sem alteração da simetria do pico e da vizinhança.

O limite de detecção foi determinado utilizando-se uma solução estoque contendo todos os padrões, a qual foi diluída sucessivamente até que a relação sinal ruído dos compostos no cromatograma fosse igual a $3: 1^{54}$.

O limite de quantificação foi determinado utilizando-se uma solução estoque contendo todos os padrões, a qual foi diluída sucessivamente até que a relação sinal ruído dos compostos no cromatograma fosse igual a 10:1 ${ }^{54}$.

A repetibilidade do método foi verificada através de nove análises consecutivas de uma solução-padrão, com concentrações definidas. A precisão desta série de medidas foi determinada pelo cálculo do desvio padrão relativo (DPR) utilizando os valores de concentração para efetuar os cálculos ${ }^{54}$. 


\subsection{Análise multivariada}

O banco de dados de resultados analíticos foi analisado utilizando os seguintes tratamentos quimiométricos:

- Análise de componentes principais

- Regressão por mínimos quadrados parciais

- Análise discriminante linear

A análise multivariada do banco de dados de resultado analítico foi realizada utilizando o software MINITAB Release 14 (Statistical Software, State College, Pennsylvania, US). 


\section{RESULTADOS E DISCUSSÕES}

A Figura 11 apresenta um cromatograma típico dos padrões de ésteres analisados no modo SIM. O ruído mostrado no cromatograma surge devido à necessidade do desligamento do detector no intervalo de tempo onde o etanol é eluído. O ruído origina-se devido ao religamento do detector.

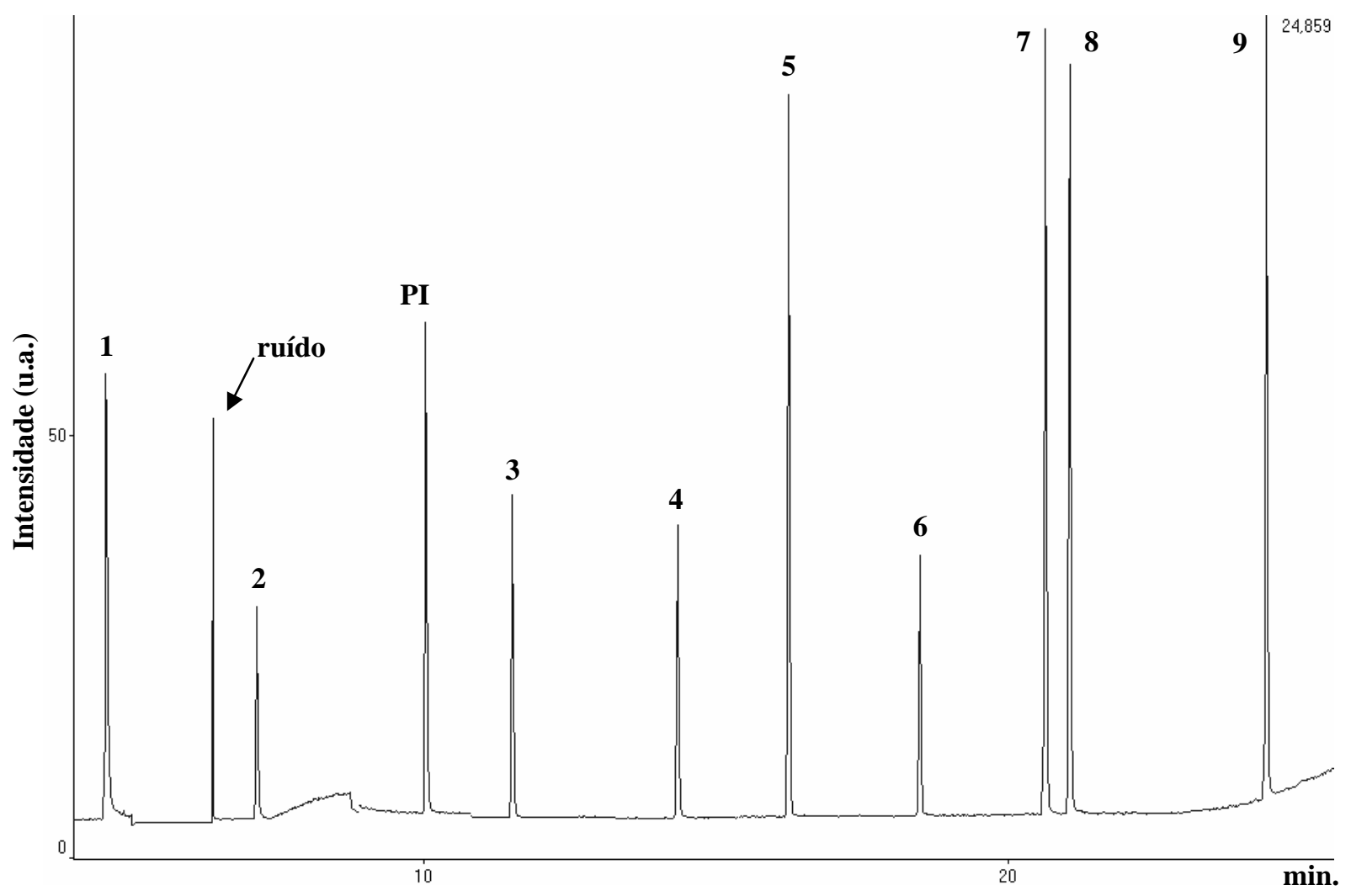

Figura 11. Cromatograma dos padrões de ésteres analisados no modo SIM. 1 acetato de etila, 2 butanoato de etila, 3 hexanoato de etila, 4 lactato de etila, 5 octanoato de etila, 6 nonanoato de etila, 7 decanoato de etila, 8 octanoato de isoamila, 9 dodecanoato de etila e PI 4-metil 2-pentanol.

Os íons utilizados nas análises no modo SIM foram escolhidos de acordo com os espectros de massas previamente obtidos para cada analito no modo de 
varredura de espectro (SCAN). Fatores como intensidade do pico e interferência foram as principais características consideradas na escolha dos íons. A Figura 12 ilustra os espectros de massas dos ésteres analisados. 

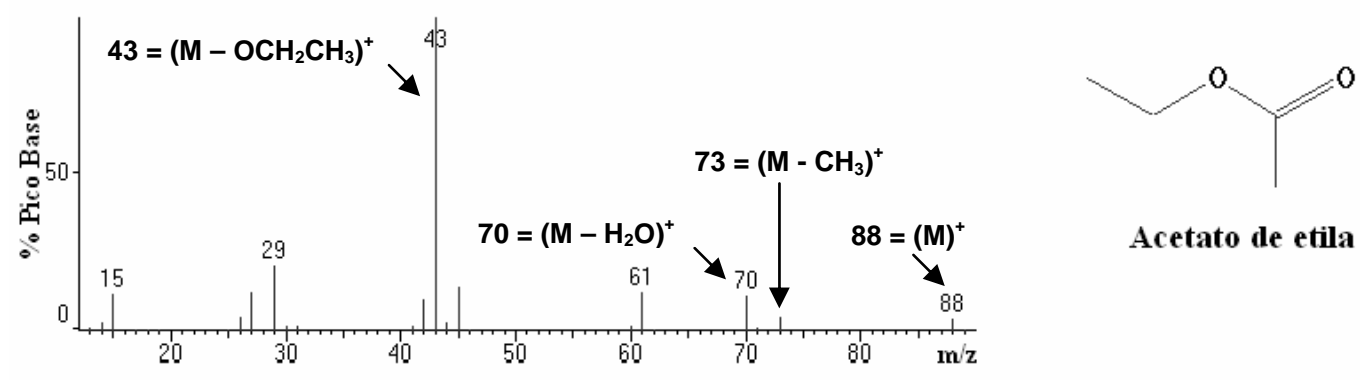

Acetato de etila
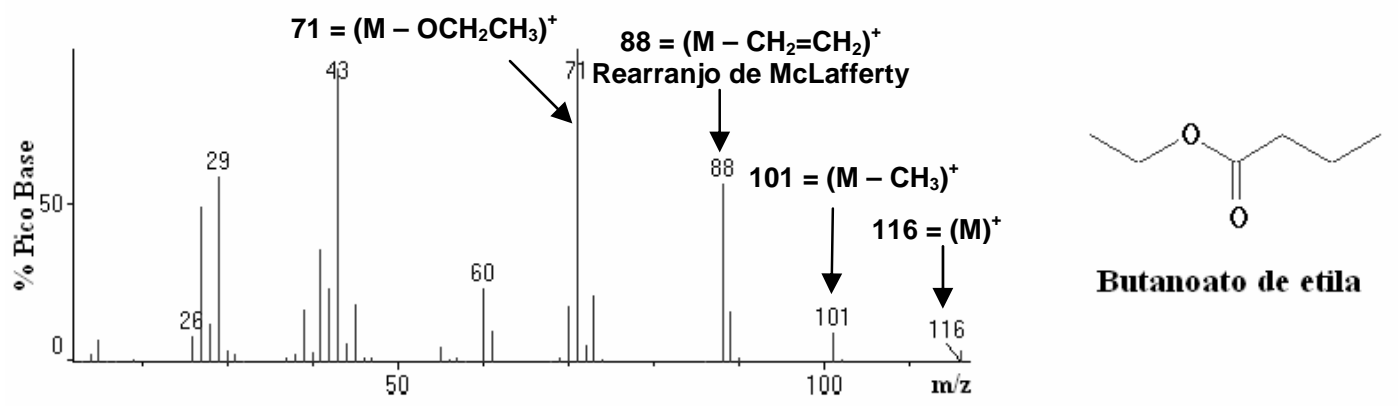

Butanoato de etila
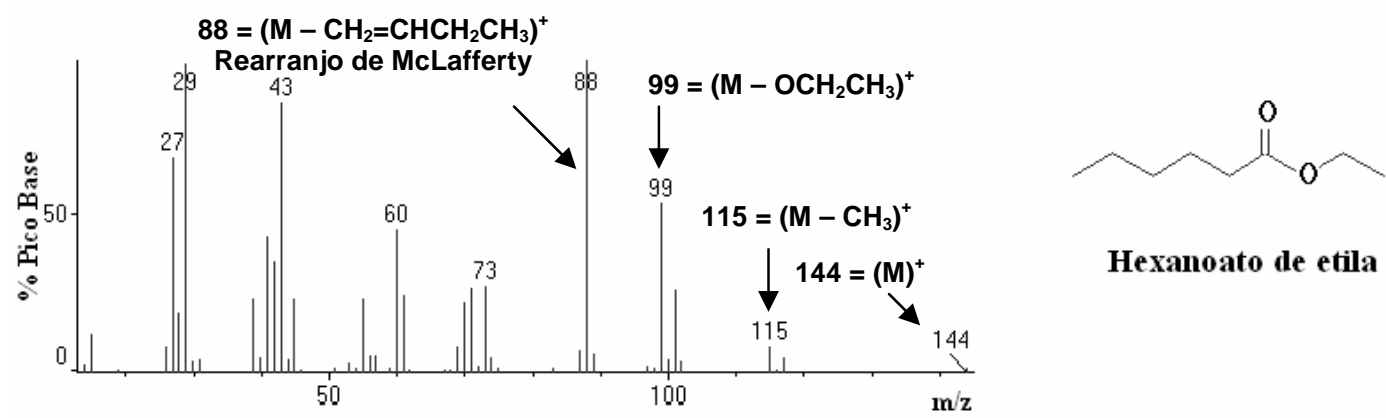

Hexanoato de etila
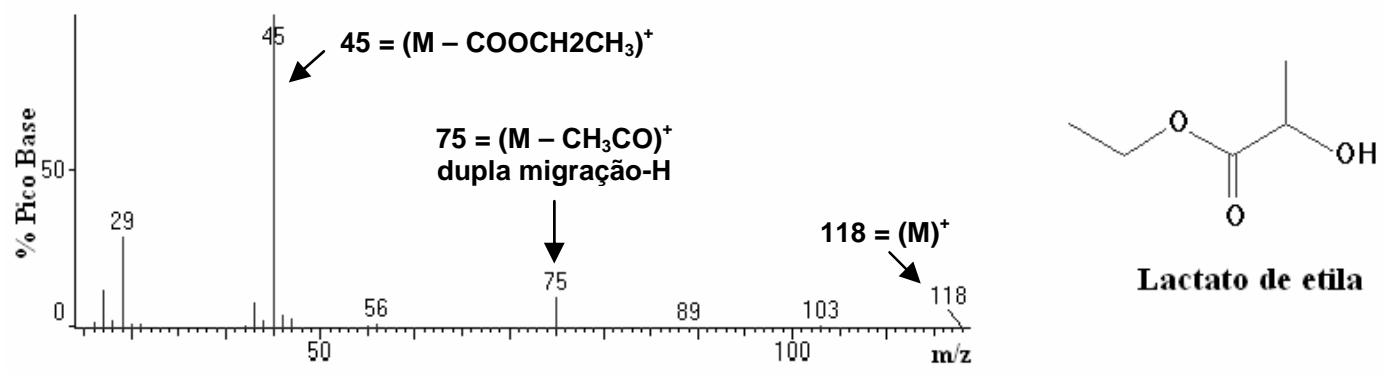

Lactato de etila

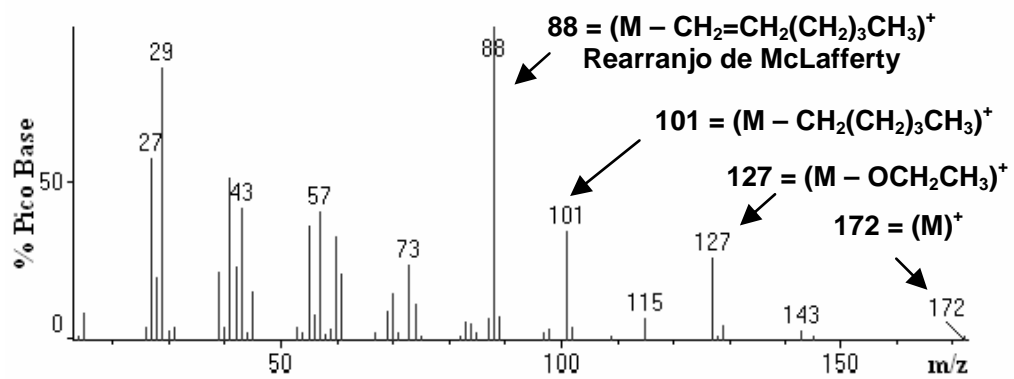<smiles>CCCCCCCC(=O)OCC</smiles>

Octanoato de etila

Figura 12. Espectros de massas dos ésteres analisados obtidos no modo SCAN. 


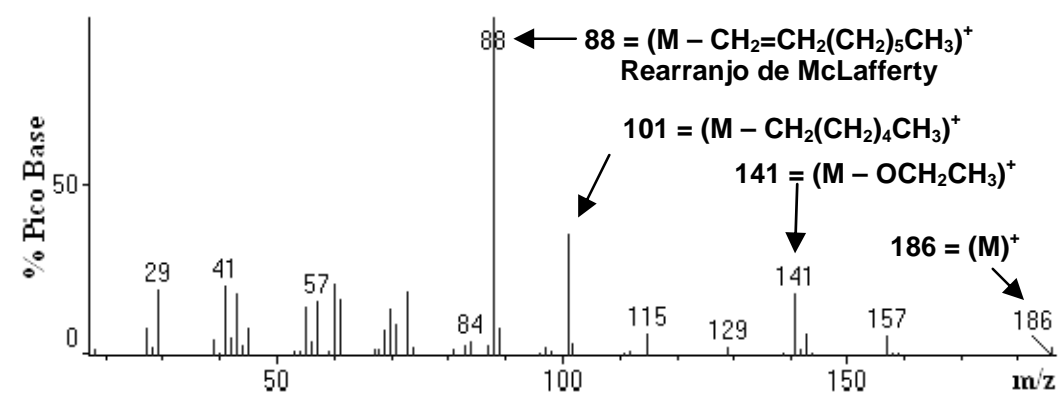<smiles>CCCCCCCCC(=O)OCC</smiles>

Nonanoato de etila<smiles>CCCCCCCCC(=O)OCC</smiles>

Decanoato de etila

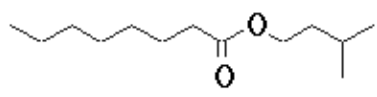

Octanoato de isoamila
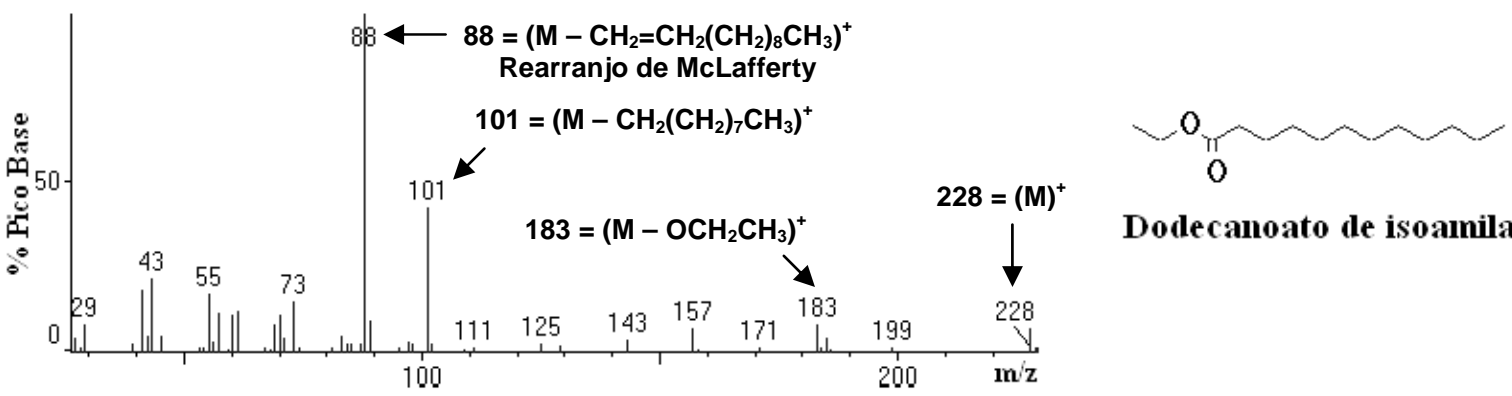

Dodecanoato de isoamila

Figura 12. Continuação. 
O íon $88 \mathrm{~m} / \mathrm{z}$ é característico de ésteres etílicos e geralmente é o íon mais intenso (pico base) dos ésteres carboxílicos de cadeia linear na faixa de $C_{6}$ a $C_{26}$. Este íon surge devido ao rearranjo de McLafferty, com quebra da ligação $\beta$ em relação ao grupo C=O e migração de hidrogênio, conforme mostra a Figura 13.

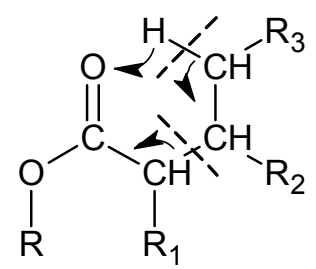<smiles>[R]C=CC(C)C(C)C(C)C</smiles><smiles>[R]CC(=[OH+])O[R]</smiles>

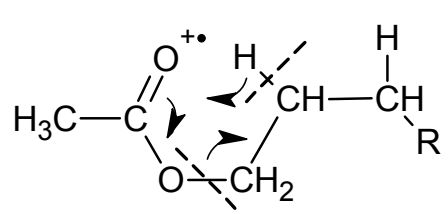

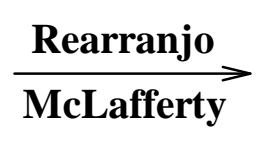<smiles>CC(=O)[OH+]</smiles><smiles>[R]C(C)C=C</smiles>

Figura 13. Rearranjo de McLafferty.

O íon $88 \mathrm{~m} / \mathrm{z}$ foi escolhido para todos os ésteres etílicos, exceto para o acetato de etila que apresentou muita interferência nesse intervalo de tempo. $\mathrm{O}$ íon $70 \mathrm{~m} / \mathrm{z}$ foi escolhido para o acetato de etila por apresentar menos interferência e por ser mais intenso que o íon $88 \mathrm{~m} / \mathrm{z}$, proporcionando uma melhor sensibilidade.

O íon 45 é o mais intenso no espectro apresentado para o lactato de etila, porém este íon não pode ser utilizado por apresentar relevante interferência com outros compostos. O íon $75 \mathrm{~m} / \mathrm{z}$ apresentou boa sensibilidade e seletividade para lactato de etila. Este íon é gerado pela perda de $\mathrm{CH}_{3} \mathrm{C} O$ com duplo rearranjo de hidrogênio. De acordo com TAJIMA, S. et $a l^{55}$ o íon $75 \mathrm{~m} / \mathrm{z}$ pode ser o formato de etila protonado $\left[\mathrm{CH}(\mathrm{OH}) \mathrm{OC}_{2} \mathrm{H}_{5}\right]^{+}$. A Figura 14 mostra a rota de fragmentação do lactato de etila para formação do íon $75 \mathrm{~m} / \mathrm{z}$. 


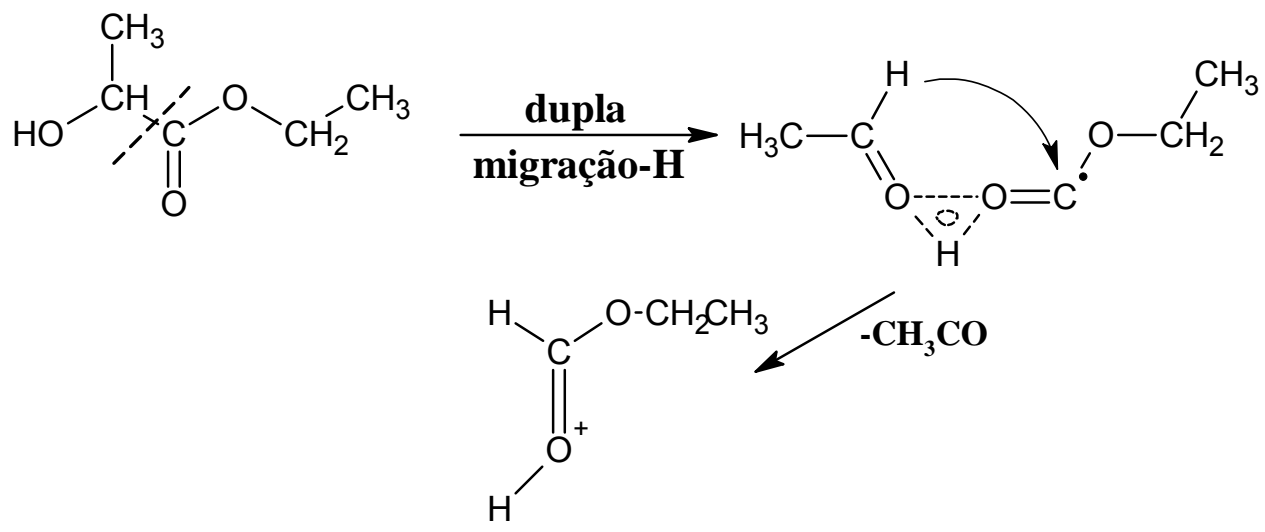

Figura 14. Mecanismo da migração dupla do átomo de hidrogênio e formação do íon $75 \mathrm{~m} / \mathrm{z}$ (adaptado da referência 55).

O íon $70 \mathrm{~m} / \mathrm{z}$ escolhido para o octanoato de isoamila é característico de ésteres derivados de álcool isoamílico e também é formado devido ao rearranjo de Mclafferty (Figura 13).

A Figura 15 apresenta um cromatograma típico de uma amostra de aguardente de cana analisada no modo SCAN e a Figura 16 apresenta um cromatograma da mesma amostra analisada no modo SIM. O pico mais intenso da Figura 15 corresponde ao álcool isoamílico. Este álcool está presente em todas as amostras de aguardente de cana em concentração relativamente elevada (ANEXO A). A Figura 16 demonstra que é possível eliminar a maioria dos interferentes, inclusive álcool isoamílico, e aumentar quantitativamente a sensibilidade do método trabalhando com o modo de monitoramento de íon seletivo. Nota-se também que é possível identificar e quantificar os ésteres escolhidos para análise sem problemas de co-eluições com outros compostos presentes na amostra e sem a necessidade de técnicas de pré-concentração da amostra. 


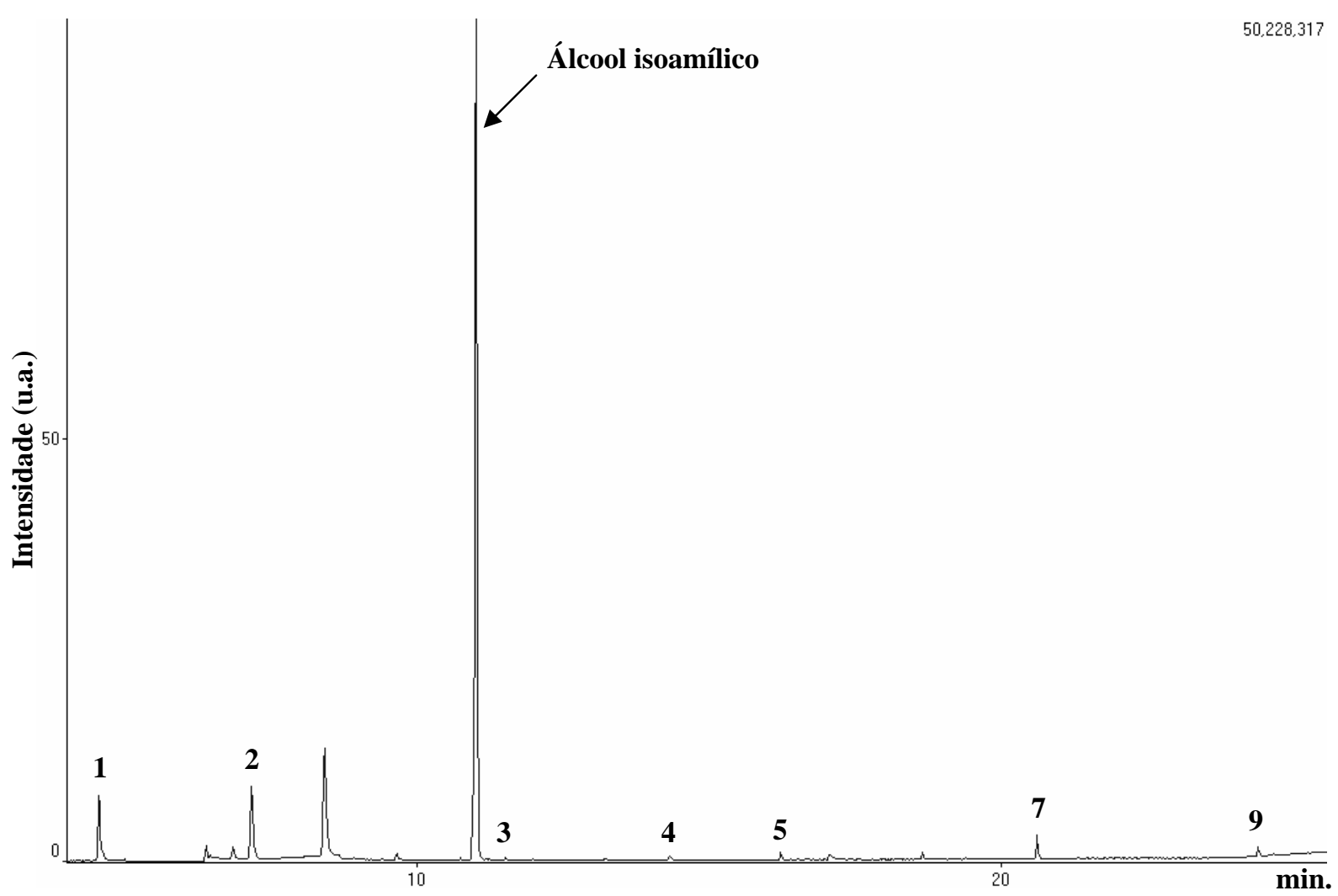

Figura 15. Cromatograma típico de uma amostra de aguardente analisada no modo SCAN. Picos: 1 acetato de etila, 2 butanoato de etila, 3 hexanoato de etila, 4 lactato de etila, 5 octanoato de etila, 7 decanoato de etila e 9 dodecanoato de etila. 


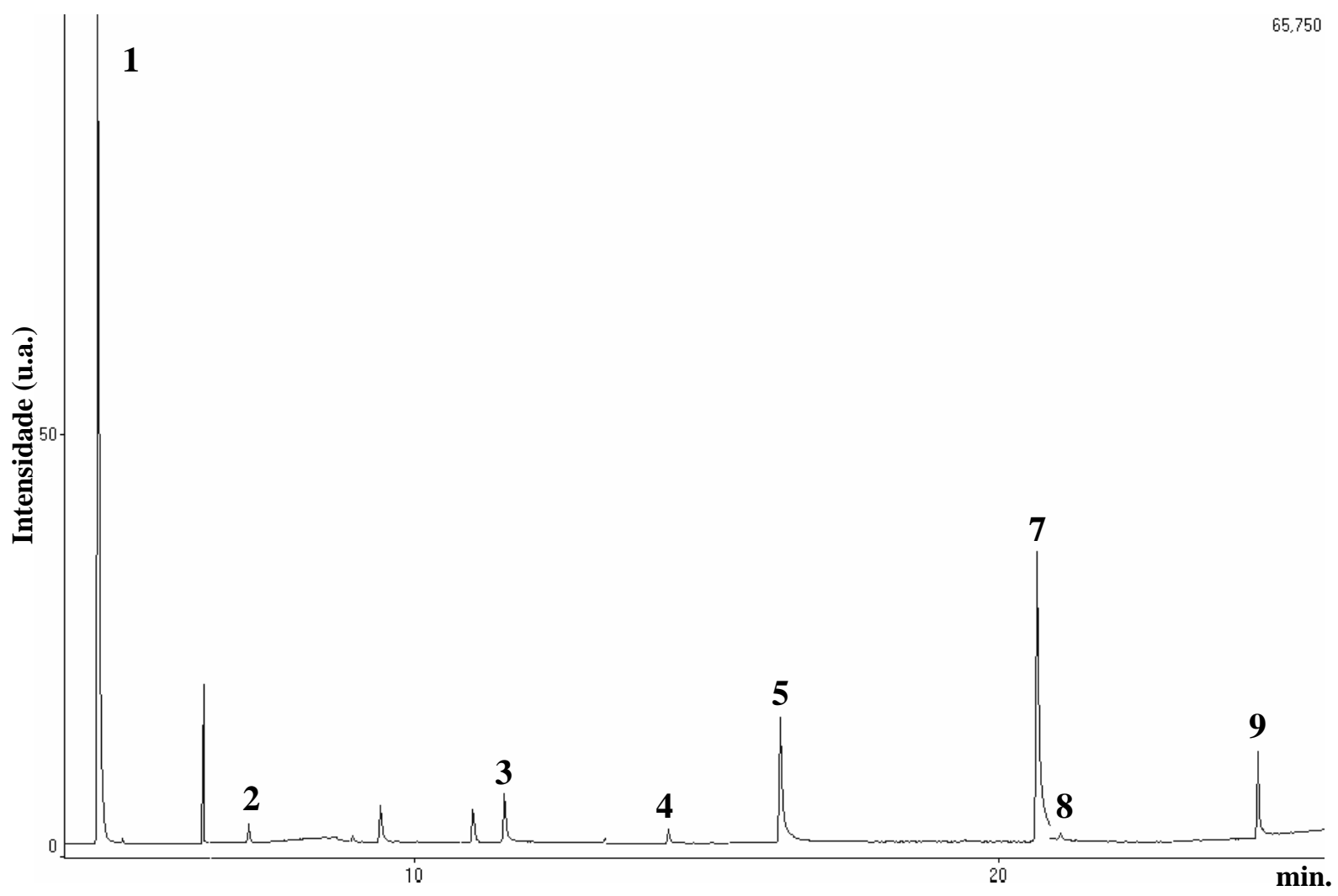

Figura 16. Cromatograma típico de uma amostra de aguardente analisada no modo SIM. Picos: 1 acetato de etila, 2 butanoato de etila, 3 hexanoato de etila, 4 lactato de etila, 5 octanoato de etila, 7 decanoato de etila, 8 octanoato de isoamila e 9 dodecanoato de etila.

A Tabela 5 lista os valores de limite de detecção, limite de quantificação e repetibilidade obtidos para a metodologia analítica desenvolvida. 
Tabela 5: Valores para o limite de detecção, limite de quantificação e repetibilidade do método utilizado no CG-EM.

\begin{tabular}{cccc}
\hline Compostos & $\begin{array}{c}\text { Limite de } \\
\text { detecção }^{\text {a }}\end{array}$ & $\begin{array}{c}\text { Limite de } \\
\text { quantificação }\end{array}$ & Repetibilidade (DPR) * \\
\hline Acetato de etila & 0,648 & 2,11 & 3,41 \\
Butanoato de etila & 0,0783 & 0,168 & 2,52 \\
Lactato de etila & 0,0547 & 0,152 & 0,774 \\
Hexanoato de etila & 0,0593 & 0,174 & 2,01 \\
Octanoato de etila & 0,0721 & 0,232 & 1,90 \\
Nonanoato de etila & 0,0457 & 0,108 & 2,60 \\
Decanoato de etila & 0,0432 & 0,147 & 3,04 \\
Octanoato de isoamila & 0,0258 & 0,0739 & 5,05 \\
Dodecanoato de etila & 0,0489 & 0,159 & 4,11 \\
\hline
\end{tabular}

* Desvio padrão relativo.

$\mathrm{a}=$ Concentração em $\mathrm{mg} \mathrm{L}^{-1}$.

\subsection{Concentrações dos ésteres nas amostras de aguardente de cana}

A Tabela 6 lista os valores para a média, mediana, valor máximo e valor mínimo da concentração para as 136 amostras de aguardente de cana analisadas.

O ANEXO A lista os valores da graduação alcoólica para as 136 amostras de aguardente de cana, utilizados para o cálculo da concentração em mg de ésteres por $100 \mathrm{~mL}^{-1}$ de álcool anidro.

A amostra 93 foi desconsiderada de todos os cálculos realizados por ter apresentado problemas em outros trabalhos realizados pelo grupo (por exemplo, concentração elevada de ácido acético) e por apresentar um perfil atípico de ésteres (Tabela 7). 
Tabela 6: Valores para a média, mediana, valor máximo e valor mínimo de concentração para os ésteres nas amostras de aguardente de cana.

\begin{tabular}{ccccc}
\hline Compostos & \multicolumn{4}{c}{ Aguardente de cana * } \\
\cline { 2 - 5 } Acetato de etila & Média & Mediana & V. máx. & V. mín. \\
Butanoato de etila & 48,7 & 22,6 & 433 & 1,56 \\
Hexanoato de etila & 0,244 & 0,136 & 2,30 & 0,0365 \\
Lactato de etila & 0,180 & 0,116 & 0,765 & 0,0342 \\
Octanoato de etila & 27,1 & 8,32 & 244 & 0,0367 \\
Nonanoato de etila & 0,559 & 0,325 & 3,60 & 0,0451 \\
Decanoato de etila & 1,35 & 0,801 & 7,33 & 0,05301 \\
Octanoato de isoamila & 0,0599 & 0,0424 & 0,234 & 0,0141 \\
Dodecanoato de etila & 0,604 & 0,344 & 4,03 & 0,0411 \\
\hline
\end{tabular}

* Concentração em mg $100 \mathrm{~mL}^{-1}$ de álcool anidro.

De acordo com a Tabela 6 o acetato de etila representa 59,3\% da concentração total de ésteres (a concentração total de ésteres foi obtida somandose as médias das concentrações obtidas na Tabela 6). Verifica-se também que o lactato de etila está presente em concentrações relativamente elevadas quando comparado aos outros ésteres, sendo o segundo éster mais abundante. Pode-se observar na Tabela 6 que o lactato de etila representa 36,2 \% da concentração total de ésteres.

Na Tabela 7 são apresentadas as concentrações de ésteres obtidas para as amostras de aguardente de cana, a partir das quais verifica-se que o acetato de etila é o éster presente em maior concentração nas amostras analisadas. 
Tabela 7: Concentrações dos ésteres nas amostras de aguardente de cana ( $\mathrm{mg} 100 \mathrm{~mL}^{-1}$ de álcool anidro).

\begin{tabular}{|c|c|c|c|c|c|c|c|c|c|}
\hline Amostras & $\begin{array}{l}\text { Acetato } \\
\text { de etila }\end{array}$ & $\begin{array}{l}\text { Butanoato } \\
\text { de etila }\end{array}$ & $\begin{array}{l}\text { Hexanoato } \\
\text { de etila }\end{array}$ & $\begin{array}{l}\text { Lactato } \\
\text { de etila }\end{array}$ & $\begin{array}{l}\text { Octanoato } \\
\text { de etila }\end{array}$ & $\begin{array}{c}\text { Nonanoato } \\
\text { de etila }\end{array}$ & $\begin{array}{c}\text { Decanoato } \\
\text { de etila }\end{array}$ & $\begin{array}{l}\text { Octanoato } \\
\text { de isoamila }\end{array}$ & $\begin{array}{c}\text { Dodecanoato } \\
\text { de etila }\end{array}$ \\
\hline Amostra 002 & 2,55 & $<$ LD & 0,0457 & 0,287 & 0,914 & $<L D$ & 3,82 & 0,100 & 1,98 \\
\hline Amostra 003 & 2,34 & 0,0857 & $<L D$ & 1,86 & 0,310 & $<L D$ & 2,41 & 0,0306 & 1,17 \\
\hline Amostra 004 & 11,6 & 0,0746 & 0,0915 & 0,0928 & 0,654 & $<$ LD & 1,17 & 0,0219 & 0,310 \\
\hline Amostra 005 & 7,02 & 0,136 & 0,401 & 0,0929 & 1,89 & 0,0377 & 6,48 & 0,115 & 4,03 \\
\hline Amostra 007 & 11,9 & 0,153 & 0,0458 & 0,0766 & 0,322 & $<$ LD & 1,42 & $<$ LD & 0,670 \\
\hline Amostra 008 & 12,8 & 0,0677 & 0,0953 & 0,0367 & 0,797 & $<$ LD & 4,46 & 0,0586 & 0,925 \\
\hline Amostra 009 & 14,3 & 0,208 & 0,209 & 0,250 & 1,27 & $<$ LD & 2,04 & 0,0995 & 0,529 \\
\hline Amostra 010 & 10,1 & 0,0879 & $<L D$ & 2,13 & 0,0534 & $<$ LD & 0,371 & $<$ LD & 0,0627 \\
\hline Amostra 014 & 13,6 & 0,133 & $<$ LD & 8,06 & $<$ LD & $<$ LD & $<$ LD & $<$ LD & $<$ LD \\
\hline Amostra 015 & 7,90 & 0,0365 & 0,0605 & 2,32 & 0,739 & 0,0253 & 2,04 & 0,0259 & 0,831 \\
\hline Amostra 016 & 32,7 & $<\mathrm{LD}$ & $<\mathrm{LD}$ & 5,15 & $<$ LD & $<\mathrm{LD}$ & $<$ LD & $<$ LD & $<$ LD \\
\hline Amostra 017 & 11,1 & 0,0697 & 0,142 & 2,42 & 1,11 & 0,0789 & 4,59 & 0,0668 & 1,41 \\
\hline
\end{tabular}


Tabela 7: Continuação.

\begin{tabular}{|c|c|c|c|c|c|c|c|c|c|}
\hline Amostras & $\begin{array}{l}\text { Acetato } \\
\text { de etila }\end{array}$ & $\begin{array}{c}\text { Butanoato } \\
\text { de etila }\end{array}$ & $\begin{array}{c}\text { Hexanoato } \\
\text { de etila }\end{array}$ & $\begin{array}{l}\text { Lactato } \\
\text { de etila }\end{array}$ & $\begin{array}{c}\text { Octanoato } \\
\text { de etila }\end{array}$ & $\begin{array}{c}\text { Nonanoato } \\
\text { de etila }\end{array}$ & $\begin{array}{c}\text { Decanoato } \\
\text { de etila }\end{array}$ & $\begin{array}{l}\text { Octanoato } \\
\text { de isoamila }\end{array}$ & $\begin{array}{c}\text { Dodecanoato } \\
\text { de etila }\end{array}$ \\
\hline Amostra 019 & 10,3 & 0,195 & 0,0872 & 0,575 & 0,456 & $<$ LD & 0,872 & 0,0373 & 0,230 \\
\hline Amostra 020 & 17,2 & 0,288 & 0,184 & 0,295 & 0,339 & 0,0209 & 0,701 & 0,0248 & 0,342 \\
\hline Amostra 021 & 65,0 & $<$ LD & $<\mathrm{LD}$ & 166 & $<$ LD & $<$ LD & $<$ LD & $<$ LD & $<$ LD \\
\hline Amostra 022 & 22,6 & 0,124 & 0,256 & 0,454 & 1,64 & 0,0577 & 4,31 & 0,0731 & 1,91 \\
\hline Amostra 024 & 16,3 & $<\mathrm{LD}$ & 0,0342 & 3,65 & 0,468 & 0,0498 & 1,77 & 0,0178 & 0,679 \\
\hline Amostra 025 & 26,9 & $<$ LD & 0,0506 & 1,40 & 0,130 & 0,0534 & 1,54 & 0,0141 & 0,344 \\
\hline Amostra 026 & 10,4 & $<$ LD & $<\mathrm{LD}$ & 8,59 & 0,428 & 0,0483 & 1,37 & 0,0206 & 0,293 \\
\hline Amostra 027 & 226 & $<$ LD & $<$ LD & 28,5 & 0,0730 & $<L D$ & 0,209 & $<$ LD & 0,0516 \\
\hline Amostra 031 & 70,3 & $<$ LD & $<$ LD & 70,4 & 0,156 & $<$ LD & 0,800 & 0,0161 & 0,586 \\
\hline Amostra 032 & 54,3 & $<\mathrm{LD}$ & $<$ LD & 111 & 0,0451 & $<$ LD & 0,549 & $<$ LD & 0,344 \\
\hline Amostra 033 & 14,7 & $<$ LD & $<$ LD & 6,25 & 0,264 & $<L D$ & 0,801 & $<$ LD & 0,241 \\
\hline Amostra 034 & 4,16 & $<$ LD & $<\mathrm{LD}$ & 4,90 & 0,199 & $<$ LD & 1,34 & 0,0278 & 0,397 \\
\hline
\end{tabular}


Tabela 7: Continuação.

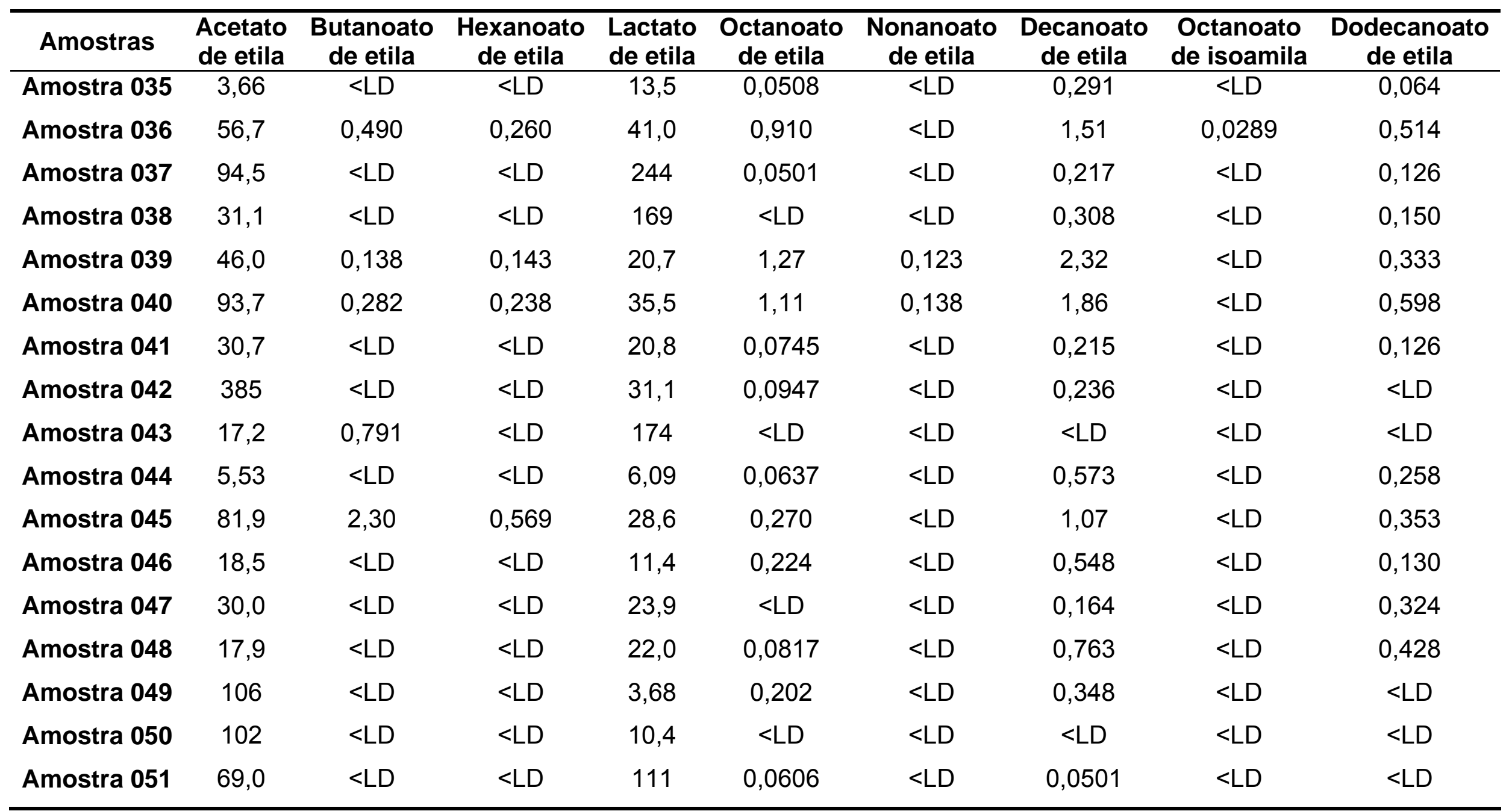


Tabela 7: Continuação.

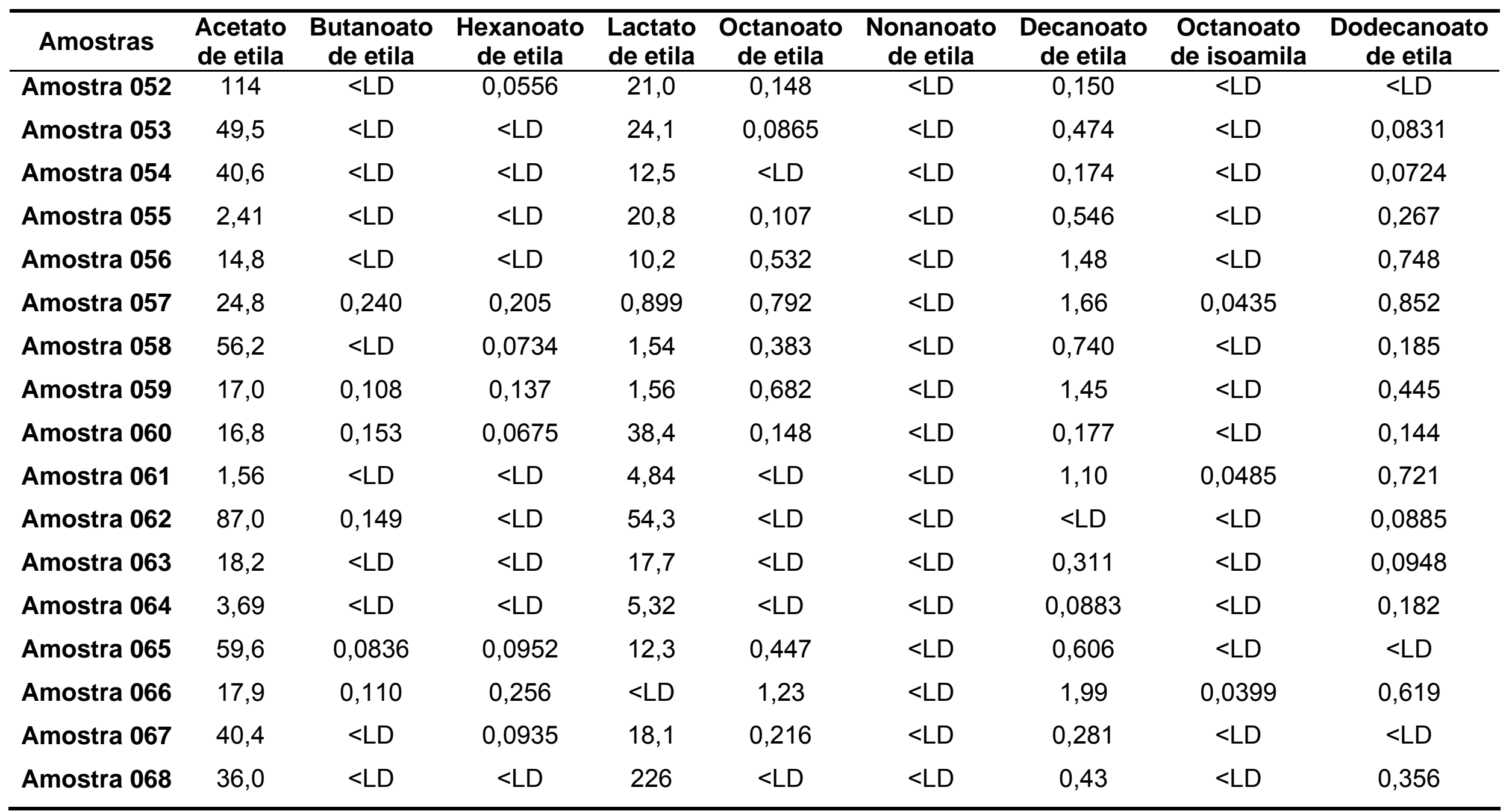


Tabela 7: Continuação.

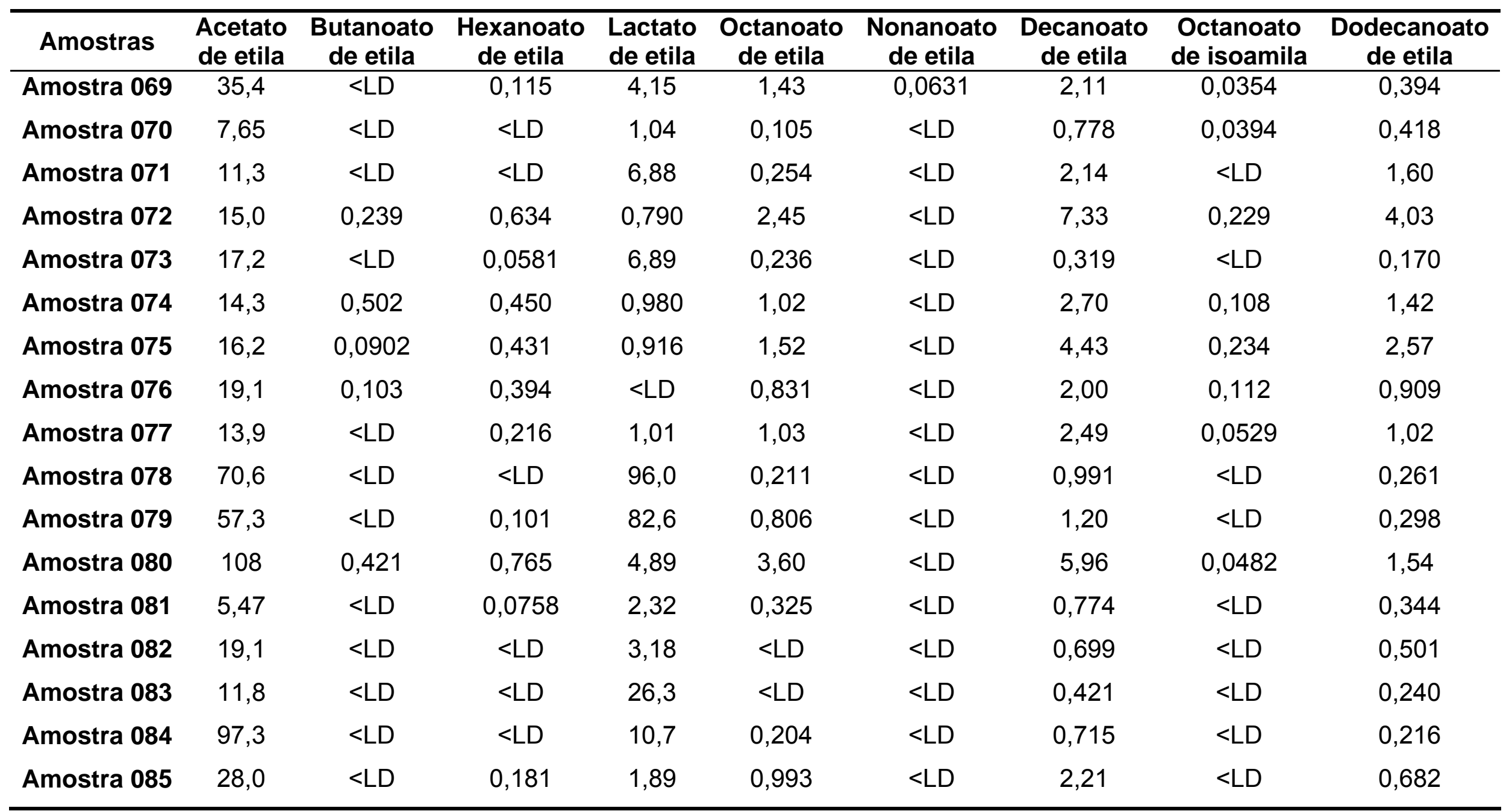


Tabela 7: Continuação.

\begin{tabular}{|c|c|c|c|c|c|c|c|c|c|}
\hline Amostras & $\begin{array}{l}\text { Acetato } \\
\text { de etila }\end{array}$ & $\begin{array}{c}\text { Butanoato } \\
\text { de etila }\end{array}$ & $\begin{array}{c}\text { Hexanoato } \\
\text { de etila }\end{array}$ & $\begin{array}{l}\text { Lactato } \\
\text { de etila }\end{array}$ & $\begin{array}{c}\text { Octanoato } \\
\text { de etila }\end{array}$ & $\begin{array}{c}\text { Nonanoato } \\
\text { de etila }\end{array}$ & $\begin{array}{c}\text { Decanoato } \\
\text { de etila }\end{array}$ & $\begin{array}{l}\text { Octanoato } \\
\text { de isoamila }\end{array}$ & $\begin{array}{c}\text { Dodecanoato } \\
\text { de etila }\end{array}$ \\
\hline Amostra 087 & 48,5 & $<$ LD & $<$ LD & 86,1 & 0,280 & $<$ LD & 0,782 & $<$ LD & 0,191 \\
\hline Amostra 088 & 102 & 0,0738 & $<$ LD & 21,3 & 0,0684 & $<$ LD & 0,132 & $<$ LD & 0,106 \\
\hline Amostra 089 & 41,4 & 0,130 & 0,0998 & 34,8 & 0,304 & $<$ LD & 0,437 & $<$ LD & 0,180 \\
\hline Amostra 090 & 51,7 & $<$ LD & $<$ LD & 35,2 & $<$ LD & $<$ LD & 0,0536 & $<$ LD & $<$ LD \\
\hline Amostra 092 & 14,6 & 0,892 & $<$ LD & 53,5 & 0,101 & $<$ LD & $<$ LD & $<$ LD & $<$ LD \\
\hline Amostra 093 & 790 & $<$ LD & 0,110 & 14,2 & 0,257 & $<$ LD & 0,225 & $<$ LD & 0,110 \\
\hline Amostra 094 & 344 & 0,614 & 0,0782 & 38,2 & 0,251 & $<$ LD & 0,451 & $<$ LD & 0,184 \\
\hline Amostra 095 & 10,5 & 0,111 & 0,156 & 0,839 & 0,629 & $<$ LD & 1,81 & 0,0413 & 0,649 \\
\hline Amostra 099 & 30,1 & $<$ LD & $<$ LD & 39,4 & 0,458 & $<$ LD & 1,58 & $<$ LD & 0,622 \\
\hline Amostra 100 & 71,6 & $<$ LD & 0,0729 & 4,72 & 0,391 & $<$ LD & 0,944 & $<L D$ & 0,253 \\
\hline Amostra 101 & 23,9 & $<$ LD & $<$ LD & 13,4 & 0,0753 & $<L D$ & 0,368 & $<$ LD & 0,211 \\
\hline Amostra 102 & 115 & $<$ LD & 0,0771 & 7,78 & 0,423 & $<$ LD & 0,803 & $<$ LD & 0,285 \\
\hline
\end{tabular}


Tabela 7: Continuação.

\begin{tabular}{|c|c|c|c|c|c|c|c|c|c|}
\hline Amostras & $\begin{array}{l}\text { Acetato } \\
\text { de etila }\end{array}$ & $\begin{array}{c}\text { Butanoato } \\
\text { de etila }\end{array}$ & $\begin{array}{c}\text { Hexanoato } \\
\text { de etila }\end{array}$ & $\begin{array}{l}\text { Lactato } \\
\text { de etila }\end{array}$ & $\begin{array}{c}\text { Octanoato } \\
\text { de etila }\end{array}$ & $\begin{array}{c}\text { Nonanoato } \\
\text { de etila }\end{array}$ & $\begin{array}{c}\text { Decanoato } \\
\text { de etila }\end{array}$ & $\begin{array}{l}\text { Octanoato } \\
\text { de isoamila }\end{array}$ & $\begin{array}{c}\text { Dodecanoato } \\
\text { de etila }\end{array}$ \\
\hline Amostra 104 & 55,1 & 0,179 & 0,0541 & 12,8 & 0,238 & $<$ LD & 0,652 & $<L D$ & 0,290 \\
\hline Amostra 105 & 141 & 0,138 & 0,118 & 6,47 & 0,451 & $<$ LD & 0,492 & $<$ LD & 0,095 \\
\hline Amostra 106 & 13,1 & 0,156 & 0,169 & 1,47 & 0,686 & $<$ LD & 2,40 & 0,0612 & 1,40 \\
\hline Amostra 107 & 18,4 & 0,0879 & 0,206 & $<$ LD & 0,732 & $<$ LD & 0,990 & 0,0390 & 0,356 \\
\hline Amostra 109 & 2,29 & $<$ LD & $<$ LD & 2,36 & $<$ LD & $<$ LD & $<$ LD & $<$ LD & $<$ LD \\
\hline Amostra 110 & 17,9 & 0,198 & $<$ LD & 33,3 & 0,268 & $<$ LD & 0,623 & $<$ LD & $<$ LD \\
\hline Amostra 111 & 3,96 & $<$ LD & $<$ LD & 7,77 & $<$ LD & $<$ LD & 0,396 & $<$ LD & $<$ LD \\
\hline Amostra 112 & 9,17 & $<$ LD & 0,138 & 1,78 & 0,668 & $<$ LD & 1,54 & $<L D$ & 0,870 \\
\hline Amostra 116 & 42,6 & 0,138 & $<$ LD & 4,4 & 0,191 & $<$ LD & 0,712 & $<$ LD & 0,248 \\
\hline Amostra 117 & 18,5 & $<$ LD & $<\mathrm{LD}$ & 77,9 & 0,0991 & $<L D$ & 1,02 & $<$ LD & 0,807 \\
\hline Amostra 118 & 11,9 & 0,106 & 0,298 & $<L D$ & 0,655 & $<L D$ & $<L D$ & 0,0518 & 0,0512 \\
\hline Amostra 119 & 16,0 & 0,111 & 0,285 & 1,28 & 0,934 & $<$ LD & 2,24 & 0,0547 & 0,952 \\
\hline
\end{tabular}


Tabela 7: Continuação.

\begin{tabular}{|c|c|c|c|c|c|c|c|c|c|}
\hline Amostras & $\begin{array}{l}\text { Acetato } \\
\text { de etila }\end{array}$ & $\begin{array}{c}\text { Butanoato } \\
\text { de etila }\end{array}$ & $\begin{array}{c}\text { Hexanoato } \\
\text { de etila }\end{array}$ & $\begin{array}{l}\text { Lactato } \\
\text { de etila }\end{array}$ & $\begin{array}{c}\text { Octanoato } \\
\text { de etila }\end{array}$ & $\begin{array}{c}\text { Nonanoato } \\
\text { de etila }\end{array}$ & $\begin{array}{c}\text { Decanoato } \\
\text { de etila }\end{array}$ & $\begin{array}{l}\text { Octanoato } \\
\text { de isoamila }\end{array}$ & $\begin{array}{c}\text { Dodecanoato } \\
\text { de etila }\end{array}$ \\
\hline Amostra 121 & 14,5 & $<$ LD & $<L D$ & 38,1 & 0,0930 & $<$ LD & 0,138 & $<$ LD & $<L D$ \\
\hline Amostra 122 & 9,45 & $<$ LD & 0,205 & 5,98 & 0,527 & $<$ LD & 1,21 & $<$ LD & 0,811 \\
\hline Amostra 123 & 106,7 & $<$ LD & $<$ LD & 65,6 & 0,836 & $<$ LD & 2,43 & $<$ LD & 0,357 \\
\hline Amostra 124 & 69,8 & 19,7 & 0,104 & 2,04 & 0,455 & $<$ LD & 1,42 & $<$ LD & 0,326 \\
\hline Amostra 126 & 3,64 & $<$ LD & $<$ LD & 5,56 & 0,0930 & $<$ LD & 0,632 & $<$ LD & 0,467 \\
\hline Amostra 127 & 27,6 & 1,79 & 0,120 & 12,0 & 0,796 & $<$ LD & 2,94 & $<$ LD & 0,665 \\
\hline Amostra 128 & 3,56 & $<$ LD & $<$ LD & 5,32 & 0,104 & $<L D$ & 1,33 & $<$ LD & 0,791 \\
\hline Amostra 129 & 16,8 & 0,195 & 0,356 & 0,981 & 1,30 & $<$ LD & 2,25 & 0,0586 & 0,654 \\
\hline Amostra 133 & 4,18 & $<$ LD & $<$ LD & 28,6 & $<$ LD & $<$ LD & 0,514 & $<$ LD & $<$ LD \\
\hline Amostra 134 & 18,3 & $<$ LD & $<$ LD & 39,3 & $<$ LD & $<$ LD & $<$ LD & $<$ LD & $<$ LD \\
\hline Amostra 135 & 7,01 & $<$ LD & $<$ LD & 68,0 & $<$ LD & $<$ LD & $<$ LD & $<$ LD & $<$ LD \\
\hline Amostra 136 & 77,6 & $<$ LD & $<$ LD & 35,5 & 0,292 & $<$ LD & 0,664 & $<$ LD & $<$ LD \\
\hline
\end{tabular}

<LD: valores abaixo do limite de detecção. 
De acordo com a legislação brasileira o valor máximo permitido para soma do teor total de ésteres expressos em acetato de etila é $200 \mathrm{mg} 100 \mathrm{~mL}^{-1}$ de álcool anidro. Dentre todas as amostras analisadas apenas nove amostras apresentaram valores acima do exigido pela legislação conforme mostrado na Tabela 8.

Tabela 8: Amostras com teores de ésteres totais acima do permitido pela legislação brasileira.

\begin{tabular}{cccc}
\hline Amostras & Ésteres totais * & Acetato de etila * & Lactato de etila * $^{*}$ \\
\hline Amostra 21 & 231,3 & 65,0 & 166 \\
Amostra 27 & 255,0 & 226 & 28,5 \\
Amostra 30 & 373,9 & 267 & 106 \\
Amostra 37 & 339,0 & 94,5 & 244 \\
Amostra 38 & 200,2 & 31,1 & 169 \\
Amostra 42 & 416,9 & 385 & 31,1 \\
Amostra 68 & 263,1 & 36,0 & 226 \\
Amostra 94 & 383,3 & 344 & 38,2 \\
Amostra 98 & 470,3 & 433 & 36,0 \\
\hline
\end{tabular}

${ }^{*}$ Concentração em mg $100 \mathrm{~mL}^{-1}$ de álcool anidro.

A metodologia para determinação de ésteres totais expressos em acetato de etila sugerida pelo MAPA em 2005 se baseia na titulação dos ésteres que foram previamente hidrolisados com hidróxido de sódio e excesso de álcali (ANEXO B). Uma vez que os consumidores e o mercado interno e externo de bebidas destiladas estão cada vez mais exigentes uma metodologia baseada na determinação por titulação não é mais eficiente, pois esta metodologia não é seletiva não permitindo a especiação, portanto limitando o resultado final ${ }^{56}$.

Assim, o MAPA sugere também a determinação dos ésteres utilizando a técnica de cromatografia gasosa equipado com um detector de ionização de chama. 
Em uma das metodologias sugerida pelo MAPA apenas o acetato de etila é monitorado (ANEXO C). O ANEXO D descreve a metodologia sugerida pelo MAPA para a análise de ésteres etílicos, a mais coerente com este trabalho. Nesta metodologia um número extenso de ésteres etílicos é monitorado (acetato de metil3-butila, acetato de hexila, acetato de fenil-2-etila, butanoato de etila, hexanoato de etila, octanoato de etila, decanoato de etila, dodecanoato de etila, tetradecanoato de etila e hexadecanoato de etila), porém os principais ésteres, acetato de etila e lactato de etila, não são monitorados. Nossos resultados indicam, conforme discutiremos abaixo, a necessidade da alteração destas recomendações ${ }^{56}$.

As amostras 21, 37, 38 e 68 apresentaram valores acima do permitido pela legislação brasileira devido, principalmente, à presença de lactato de etila em concentração elevada. Esse dado revela a importância de se monitorar o lactato de etila juntamente com o acetato de etila, pois para o caso das amostras $21,37,38$ e 68 se apenas o acetato de etila fosse monitorado o teor total de ésteres seria subestimado.

A presença de lactato de etila na aguardente de cana está relacionada com a contaminação do mosto por bactérias (Lactobacillus spp) responsáveis pela fermentação láctica. A origem destas bactérias no mosto esta associada à própria matéria prima (cana-de-açúcar, levedura e água) e ao local de produção (planta) da bebida.

Durante a fermentação láctica as bactérias do ácido láctico utilizam substratos que não são fermentados pelas leveduras, os quais podem ser dextranas residuais e pentoses. Vários metabólitos são produzidos, dos quais os mais abundantes são ácido acético e ácido láctico. A fermentação láctica não afeta o rendimento do destilado e acredita-se até que se traga uma contribuição positiva para o "flavour" da 
bebida, embora os parâmetros dessa contribuição ainda não sejam compreendidos $^{57}$.

De acordo com GEDDES, P. A. e RIFFKIN, H. L. ${ }^{57}$ a formação de acetaldeído, substância de alguma forma relacionada com as dores de cabeça após a ingestão de bebidas alcoólicas, e a formação de acetato de etila diminuem devido à formação lactato de etila. A Figura 17 e a Figura 18 mostram a distribuição desses dados. Observa-se na Figura 17 que esta tendência é evidente nas amostras que se encontram nos extremos do gráfico, ou seja, aquelas cujas concentrações de acetaldeído e lactato de etila são elevadas. As concentrações de acetaldeído são apresentadas no ANEXO A.

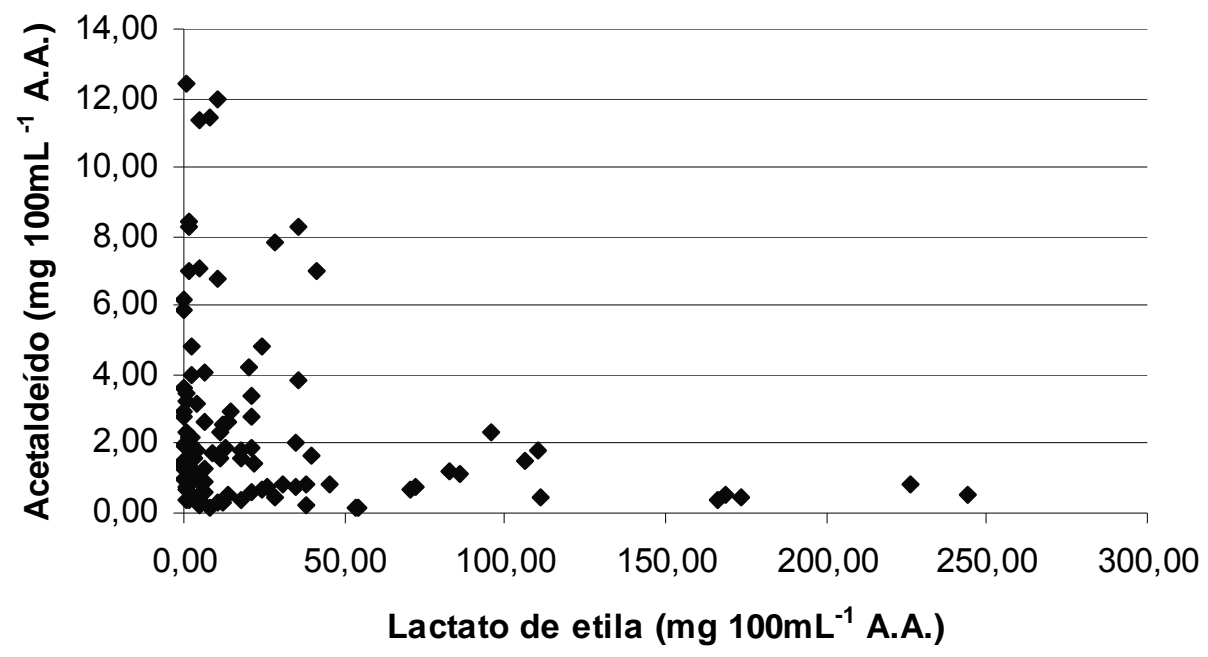

Figura 17. Relação entre a concentração de acetaldeído e a concentração de lactato de etila nas amostras de aguardente de cana.

Os dados da Figura 18 não são tão evidentes quanto os da Figura 17, e não se observa uma correlação clara entre esses dados. 


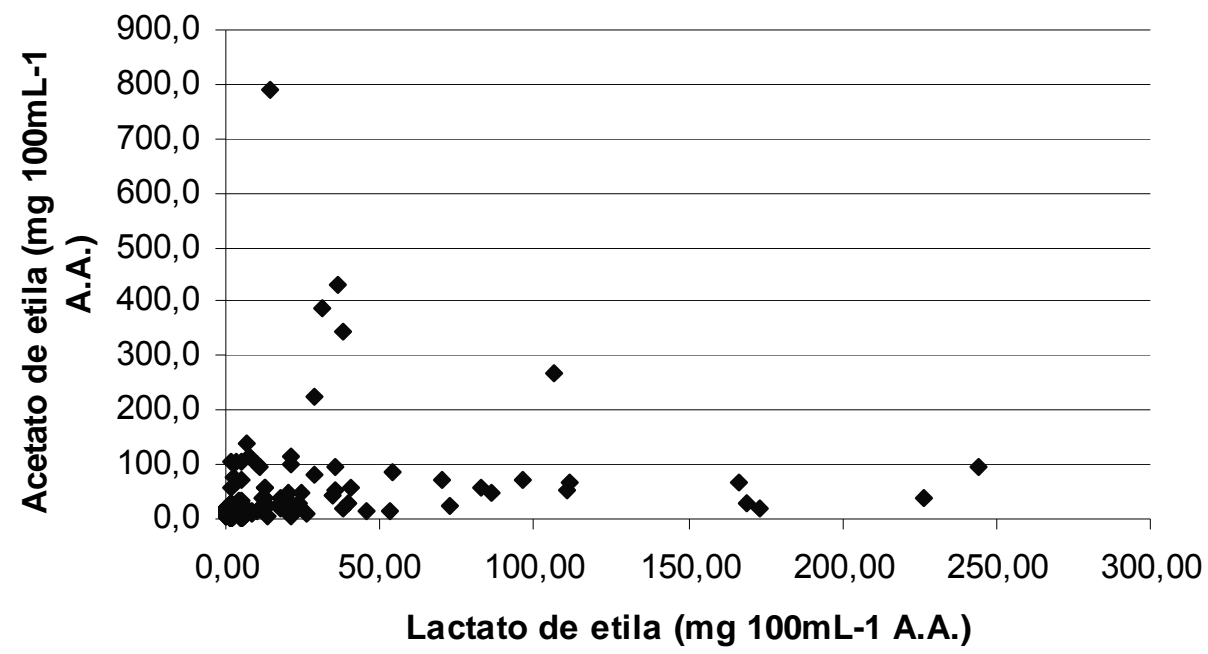

Figura 18. Relação entre a concentração de acetato de etila e a concentração de lactato de etila nas amostras de aguardente de cana.

\subsubsection{A influência do sistema de destilação sobre o perfil de ésteres do destilado}

Em conseqüência do aumento da produção de aguardente de cana, existe a tendência de substituir o sistema de destilação tradicional em alambique de cobre (sistema descontínuo) pela a destilação em coluna (sistema contínuo). A partir do questionário (ANEXO E) respondido pelos produtores durante o decorrer da coleta das amostras (in loco) foi possível identificar que dentre as amostras estudadas, 68 foram destiladas em alambiques de cobre e 27 em coluna. Para as demais 41 amostras foram utilizados sistemas de destilação mistos, por exemplo, alambique de cobre e serpentina de inox ou alambique de inox e serpentina de cobre (ANEXO F).

As Tabelas 09, 10 e 11 listam os valores para a média, mediana, valor máximo e valor mínimo de concentração de ésteres para as amostras de aguardente 
de cana destiladas em alambique de cobre, alambique misto e coluna de aço inox, respectivamente.

Tabela 9: Valores para a média, mediana, valor máximo, valor mínimo de concentração para os ésteres nas amostras de aguardente de cana destiladas em alambique de cobre.

\begin{tabular}{ccccc}
\hline Compostos & \multicolumn{4}{c}{ Alambique de cobre * } \\
\cline { 2 - 5 } Acetato de etila & Média & Mediana & V. máx. & V. mín. \\
Butanoato de etila & 53,5 & 30,4 & 385 & 2,34 \\
Hexanoato de etila & 0,360 & 0,138 & 2,30 & 0,0836 \\
Lactato de etila & 0,162 & 0,101 & 0,765 & 0,0176 \\
Octanoato de etila & $0,43,5$ & 12,3 & 244 & 0,287 \\
Nonanoato de etila & 0,0852 & 0,0631 & 0,138 & 0,0483 \\
Decanoato de etila & 1,05 & 0,699 & 5,96 & 0,0501 \\
Octanoato de isoamila & 0,0396 & 0,0354 & 0,100 & 0,0141 \\
Dodecanoato de etila & 0,465 & 0,333 & 1,98 & 0,0411 \\
\hline
\end{tabular}

* Concentrações em mg $100 \mathrm{~mL}^{-1}$ de álcool anidro. 
Tabela 10: Valores para a média, mediana, valor máximo e valor mínimo de concentração para os ésteres nas amostras de aguardente de cana destiladas em alambique misto.

\begin{tabular}{ccccc}
\hline Compostos & \multicolumn{4}{c}{ Alambique misto * } \\
\cline { 2 - 5 } Acetato de etila & Média & Mediana & V. máx. & V. mín. \\
Butanoato de etila & 60,6 & 45,0 & 433 & 1,56 \\
Hexanoato de etila & 0,256 & 0,140 & 0,892 & 0,0723 \\
Lactato de etila & 0,143 & 0,0884 & 0,454 & 0,0342 \\
Octanoato de etila & $0,36,4$ & 21,0 & 166 & 1,34 \\
Nonanoato de etila & 0,0498 & 0,0498 & 0,0498 & 0,0498 \\
Decanoato de etila & 0,855 & 0,740 & 3,44 & 0,0883 \\
Octanoato de isoamila & 0,0345 & 0,0240 & 0,0766 & 0,0161 \\
Dodecanoato de etila & 0,344 & 0,250 & 1,20 & 0,0627 \\
\hline
\end{tabular}

* Concentrações em mg $100 \mathrm{~mL}^{-1}$ de álcool anidro.

Tabela 11: Valores para a média, mediana, valor máximo e valor mínimo de concentração para os ésteres nas amostras de aguardente de cana destiladas em coluna de aço inox.

\begin{tabular}{ccccc}
\hline Compostos & \multicolumn{4}{c}{ Coluna de aço inox * } \\
\cline { 2 - 5 } Acetato de etila & Média & Mediana & V. máx. & V. mín. \\
Butanoato de etila & 26,7 & 14,1 & 344 & 6,95 \\
Hexanoato de etila & 0,170 & 0,124 & 0,614 & 0,0365 \\
Lactato de etila & 0,199 & 0,149 & 0,634 & 0,0458 \\
Octanoato de etila & 0,22 & 0,869 & 38,4 & 0,0367 \\
Nonanoato de etila & 0,0441 & 0,0377 & 0,0789 & 0,0209 \\
Decanoato de etila & 2,37 & 2,00 & 7,33 & 0,177 \\
Octanoato de isoamila & 0,0796 & 0,0612 & 0,234 & 0,0219 \\
Dodecanoato de etila & 1,06 & 0,750 & 4,03 & 0,119 \\
\hline
\end{tabular}

${ }^{*}$ Concentrações em mg $100 \mathrm{~mL}^{-1}$ de álcool anidro. 
A Figura 19 ilustra um histograma da mediana da concentração de cada analito de acordo com o sistema de destilação utilizado, ou seja, alambique de cobre, alambique misto ou coluna de aço inox. A Figura 20 apresenta um histograma da mediana da concentração de cada analito de acordo com o sistema de destilação utilizado, porém sem as medianas das concentrações de acetato de etila e lactato de etila, apenas para uma melhor visualização da Figura 19.

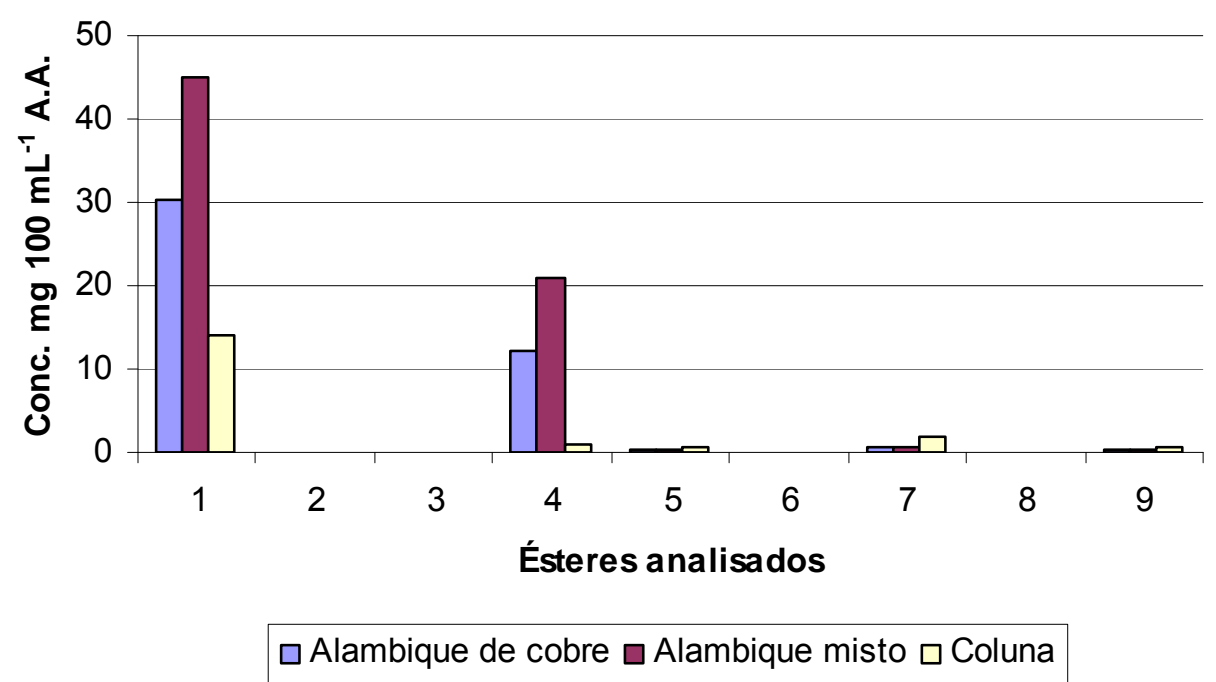

Figura 19. Histograma da mediana da concentração de cada analito de acordo com o sistema de destilação utilizado para as amostras de aguardente de cana. 1 acetato de etila, 2 butanoato de etila, 3 hexanoato de etila, 4 lactato de etila, 5 octanoato de etila, 6 nonanoato de etila, 7 decanoato de etila, 8 octanoato de isoamila, 9 dodecanoato de etila. 


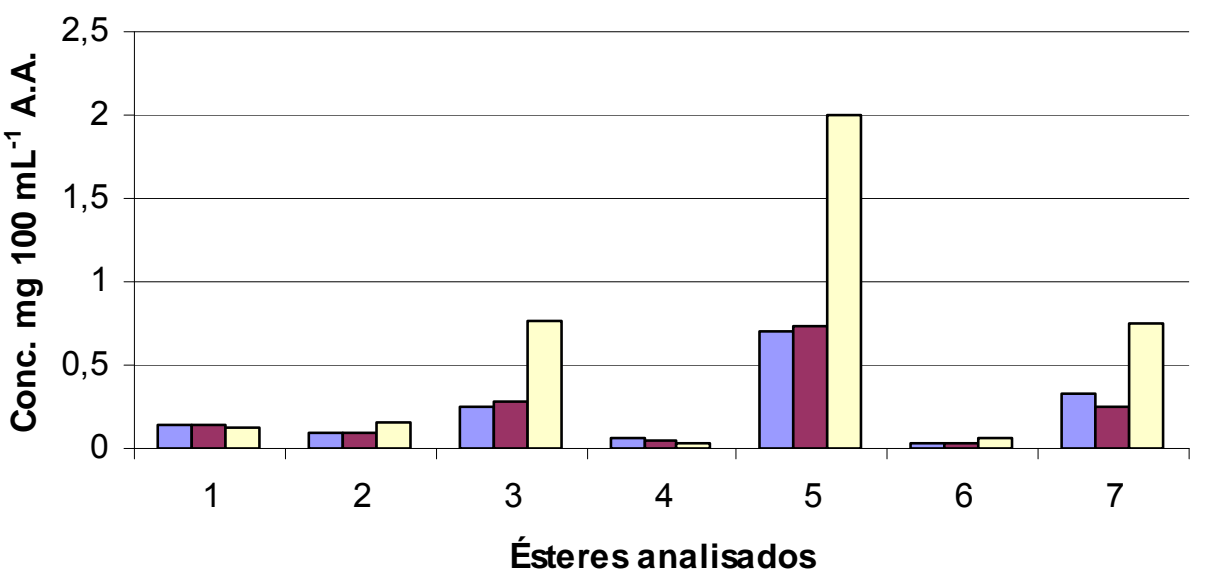

$\square$ Alambique de cobre $\square$ Alambique misto $\square$ Coluna

Figura 20. Histograma da mediana da concentração de cada analito de acordo com o sistema de destilação utilizado para as amostras de aguardente de cana. 1 butanoato de etila, 2 hexanoato de etila, 3 octanoato de etila, 4 nonanoato de etila, 5 decanoato de etila, 6 octanoato de isoamila e 7 dodecanoato de etila.

Pode-se observar na Figura 19 que as amostras de aguardente de cana que foram destiladas em alambiques de cobre e alambiques mistos apresentaram uma maior concentração de acetato de etila e lactato de etila. Na Figura 20 observa-se que as amostras destiladas em coluna apresentaram uma maior concentração de octanoato de etila, decanoato de etila e dodecanoato de etila.

A Figura 21 mostra um histograma da mediana da concentração total de ésteres em mg $100 \mathrm{~mL}^{-1}$ de álcool anidro de acordo com o sistema de destilação utilizado para as amostras de aguardente de cana. 


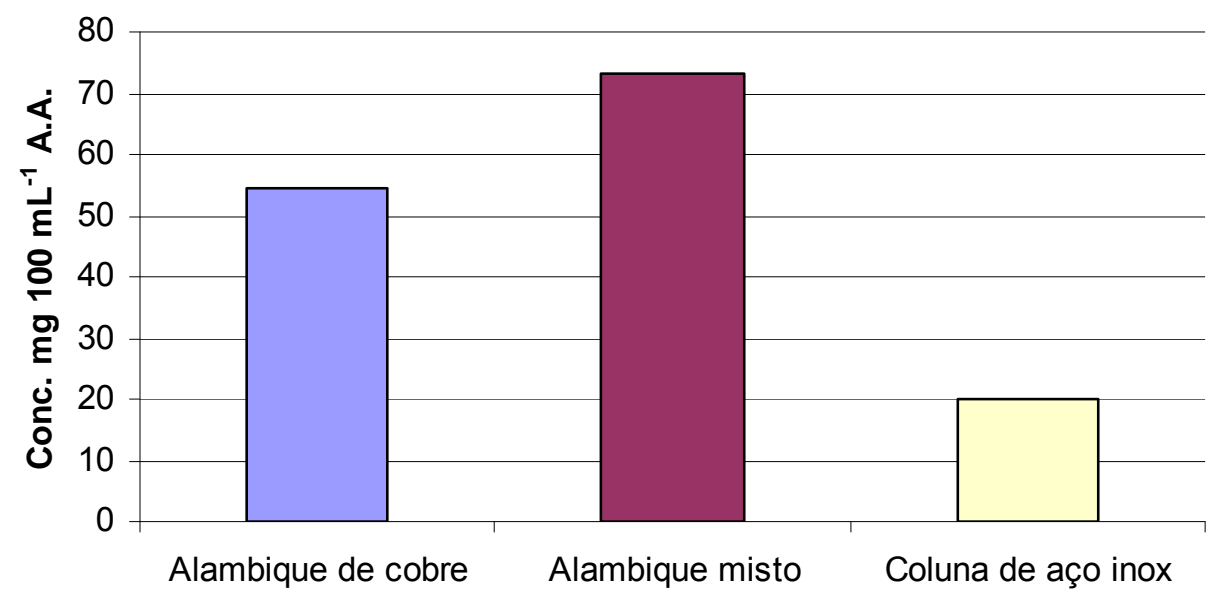

Tipo de destilador

Figura 21. Histograma da mediana da concentração total de ésteres para as amostras de aguardente de cana de acordo com o sistema de destilação utilizado.

As amostras de aguardente de cana que utilizaram o alambique misto como sistema de destilação apresentaram um teor total de ésteres $25,7 \%$ e $72,7 \%$ superior às amostras que utilizaram os sistemas de destilação de alambique de cobre e coluna de aço inox, respectivamente. Estes dados estão de acordo com dados anteriores obtidos pelo $\operatorname{LDQA}^{58}$ onde amostras de vinhos (caldos fermentados) foram destiladas nas mesmas condições experimentais em dois alambiques de 20 litros, um de cobre e o outro de aço inox. Os resultados mostraram que os vinhos que foram destilados no alambique de aço inox apresentaram teores de ésteres (acetato de etila) superiores aos vinhos que foram destilados em alambique de cobre. Os alambiques mistos mencionados neste trabalho se referem aos alambiques constituídos totalmente de aço inox ou alambiques de cobre com partes em aço inox ou alambiques de aço inox com partes em cobre. 


\subsubsection{Análise multivariada}

Diante do fato de que as amostras destiladas em alambiques de cobre apresentaram um teor de ésteres mais elevado do que as amostras destiladas em colunas de aço inox tentou-se utilizar a análise multivariada com o intuito de buscar correlações entre os dados obtidos e assim a distinção entre os dois produtos, aguardente de cana de alambique e aguardente de cana de coluna.

A maioria dos alambiques utilizados pelos produtores no processo de destilação é de cobre e a maioria das colunas é de aço inoxidável com sistema de refrigeração em cobre, portanto, alambiques de inox ou com partes em inox são exceções utilizadas como tentativa de alterações na qualidade e nas características do produto final. Assim, optou-se por explorar os resultados analíticos (banco de dados) dividindo em dois grupos: aguardente de cana destilada em alambique típico de cobre (68 amostras) e aguardente de cana destilada em coluna de aço inox (27 amostras).

\subsubsection{Análise de componentes principais}

A análise de componentes principais foi utilizada com a intenção de realizar uma análise exploratória do banco de dados (136 amostras de aguardente de cana) para visualizar a existência ou não de agrupamentos das amostras de aguardente que foram submetidas a diferentes processos de destilação. 
A Figura 22 apresenta o gráfico de pontuação obtido na separação considerando PC 1 x PC 2. Utilizou-se uma matriz de correlação para a realização da análise de PCA, pois esta normaliza o banco de dados original. O banco de dados original foi autoescalado. A soma dos valores obtidos para as duas primeiras componentes principais (PC $1(50,4 \%)$ e PC $2(19,3 \%)$ ) apresentaram uma explicação de 69,7 \% do total da variância do banco de dados.

\section{Gráfico de pontuação}

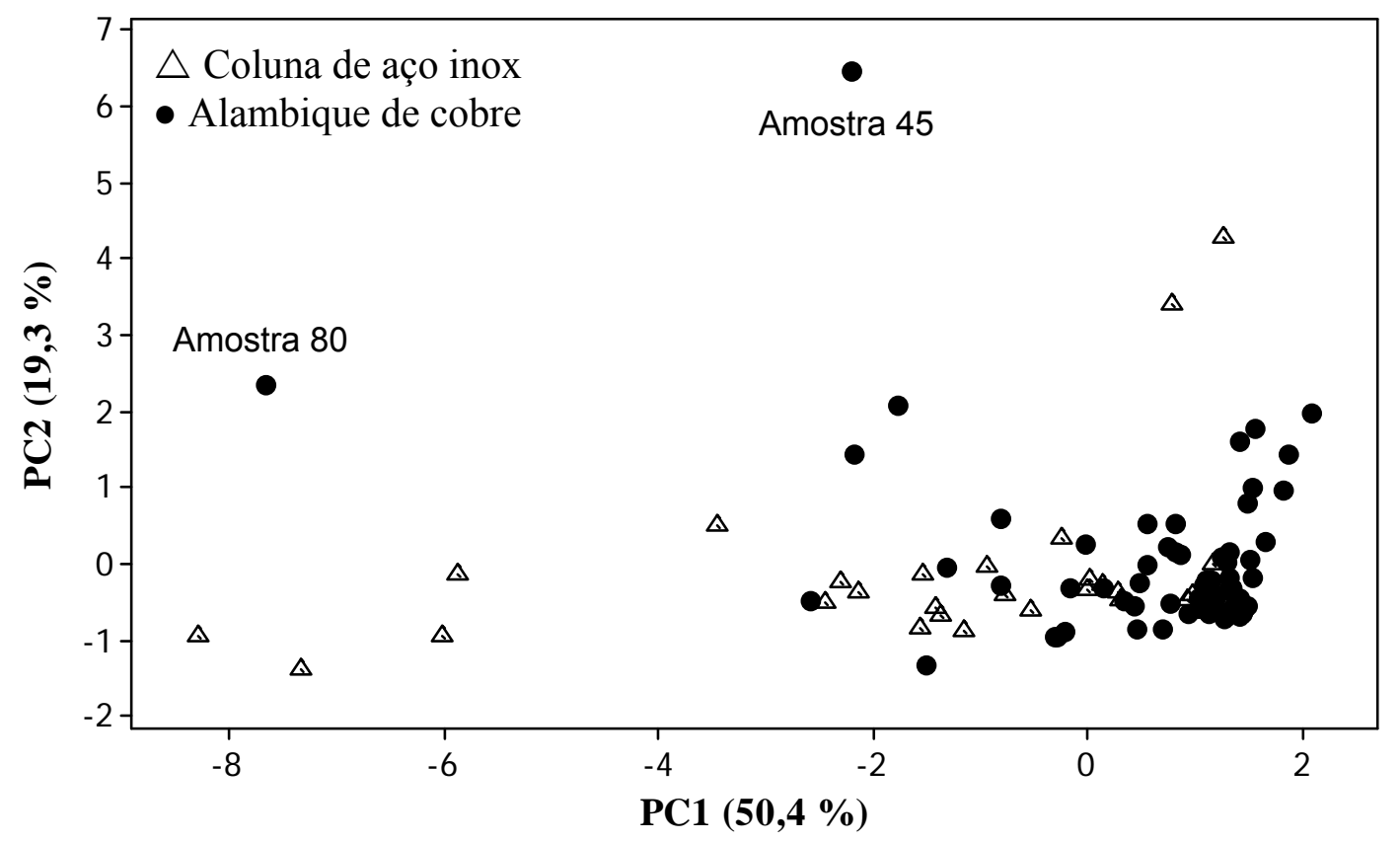

Figura 22. Gráfico de pontuação obtido para as 136 amostras de aguardente de cana utilizando os ésteres como discriminantes.

Pode-se observar na Figura 22 que as amostras destiladas em alambiques de cobre tendem a ficar agrupadas, porém as amostras destiladas em coluna de aço inox ficaram espalhadas pelo gráfico.

O gráfico de pesos (Figura 23) apresenta os compostos mais importantes para a separação obtida. 


\section{Gráfico de pesos}

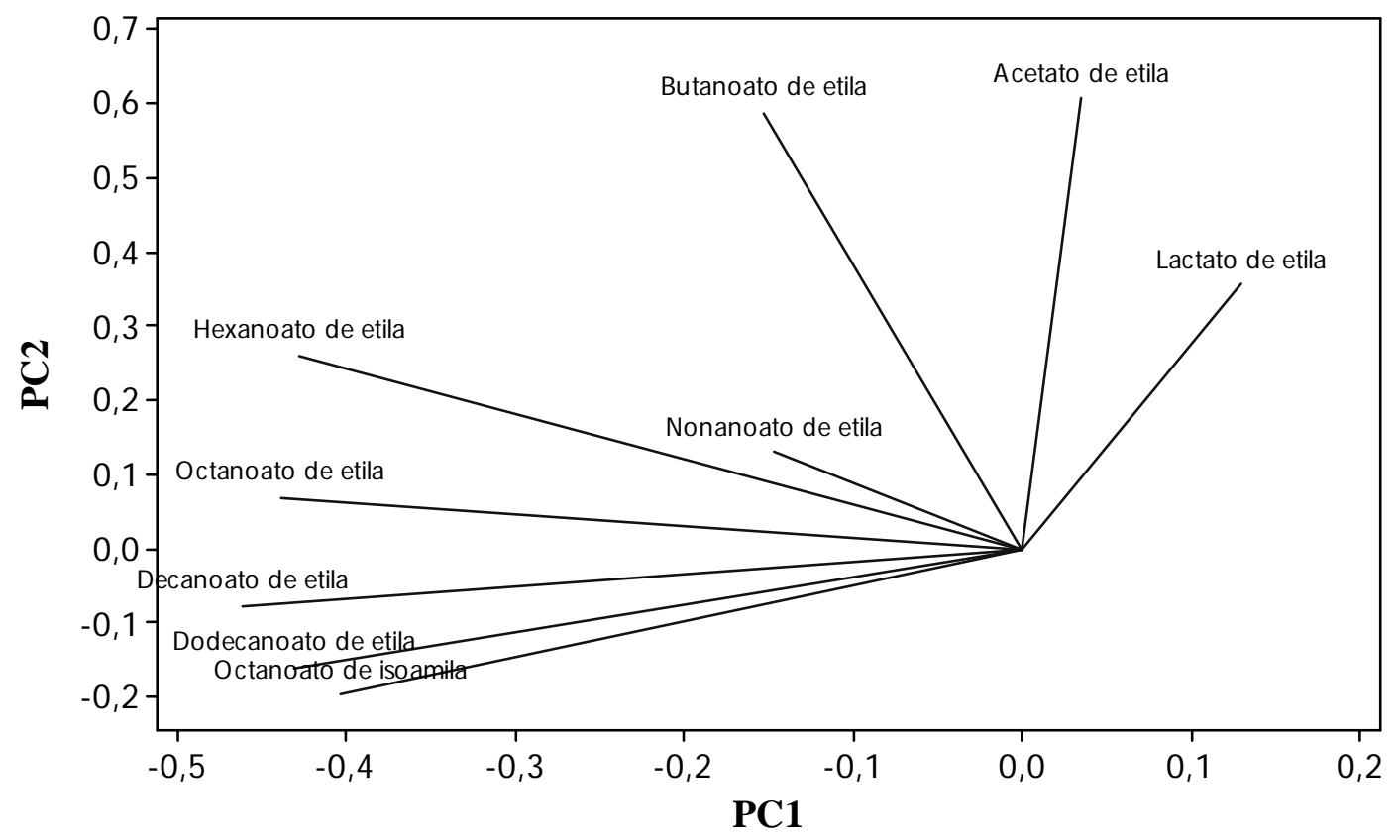

Figura 23. Gráfico de pesos obtido para as 136 amostras de aguardente de cana utilizando os ésteres como discriminantes.

Em um trabalho anterior realizado pelo $\operatorname{LDQA}^{53}$ utilizando 107 das 136 amostras de aguardente de cana estudadas neste trabalho, foi possível realizar uma distinção entre aguardente de cana destilada em alambique de cobre das destiladas em coluna. Um total de 35 analitos foram analisados sendo que seis apresentaram melhores propriedades discriminantes. Estes discriminantes foram: formaldeído, propinaldeído, 5-hidroximetilfurfural, carbamato de etila, benzaldeído e ácido acético. Um novo banco de dados foi criado utilizando os discriminantes citados anteriormente e os dados obtidos para os ésteres, com a finalidade de se obter uma melhor distinção entre esses dois grupos.

O novo banco de dados agora com 107 amostras de aguardente de cana possui 55 amostras que foram destiladas em alambique de cobre, 27 amostras que foram destiladas em coluna de aço inox e 25 amostras que foram destiladas em 
alambique misto. Apenas as amostras que foram destiladas em alambiques de cobre e em colunas de aço inox foram consideradas na separação.

A Figura 24 mostra o gráfico de pontuação obtido na separação considerando PC 1 x PC 2. Utilizou-se uma matriz de correlação para a realização da análise de PCA e o banco de dados original foi autoescalado. A soma dos valores obtidos para as duas primeiras componentes principais (PC $1(53,7 \%)$ e PC $2(27,3 \%)$ ) apresentaram uma explicação de 81,0 \% do total da variância do banco de dados.

As concentrações de carbamato de etila e benzaldeído estão apresentadas no ANEXO A.

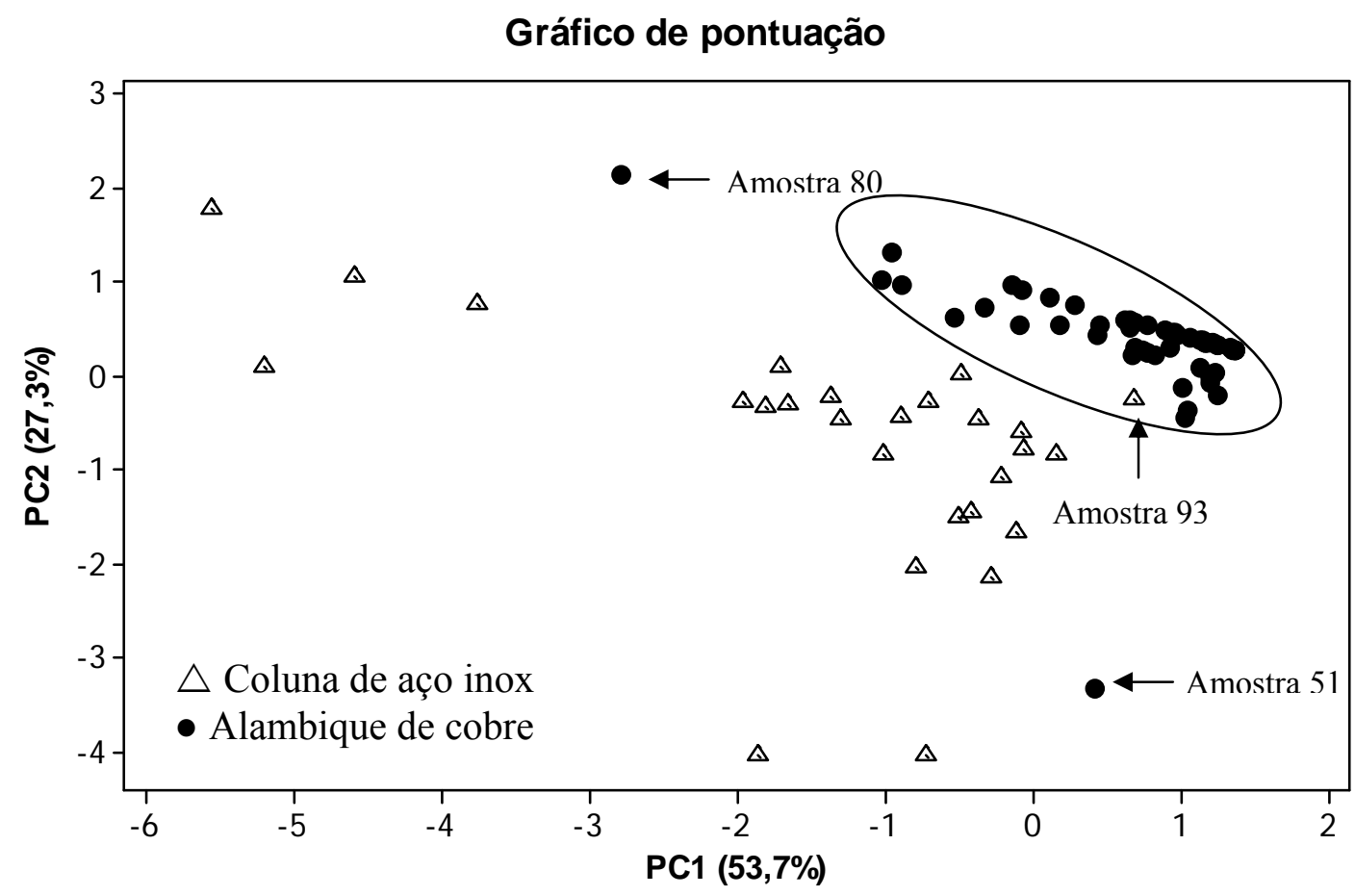

Figura 24. Gráfico de pontuação obtido para as 82 amostras de aguardente de cana utilizando o novo banco de dados (107 amostras).

Foi possível observar na Figura 24 a existência de dois grupos, um representando as amostras de aguardente de cana destiladas em alambique de 
cobre (grupo •) e o outro representando as amostras destiladas em coluna de aço inox (grupo $\triangle$ ). As amostras de aguardente de cana de alambique de cobre estão mais agrupadas do que as amostras de aguardente de cana de coluna de aço inox.

Dentre os analitos presentes no novo banco de dados os que apresentaram melhores propriedades discriminantes foram: carbamato de etila, benzaldeído, decanoato de etila e dodecanoato de etila.

Observa-se na Figura 24 que as amostras 51 e 80 ficaram um pouco afastadas de seu grupo de origem (alambique) e que a amostra 93 pertencente ao grupo das amostras de coluna foi classificada no grupo das amostras de alambique. Uma possível causa para que amostra 93 tenha sido classificada no grupo das amostras de alambique é que os valores das concentrações de decanoato de etila e dodecanoato de etila ficaram abaixo dos valores encontrados para a maioria das amostras destiladas em coluna.

O gráfico de pesos (Figura 25) apresenta os compostos mais importantes para a separação obtida. 


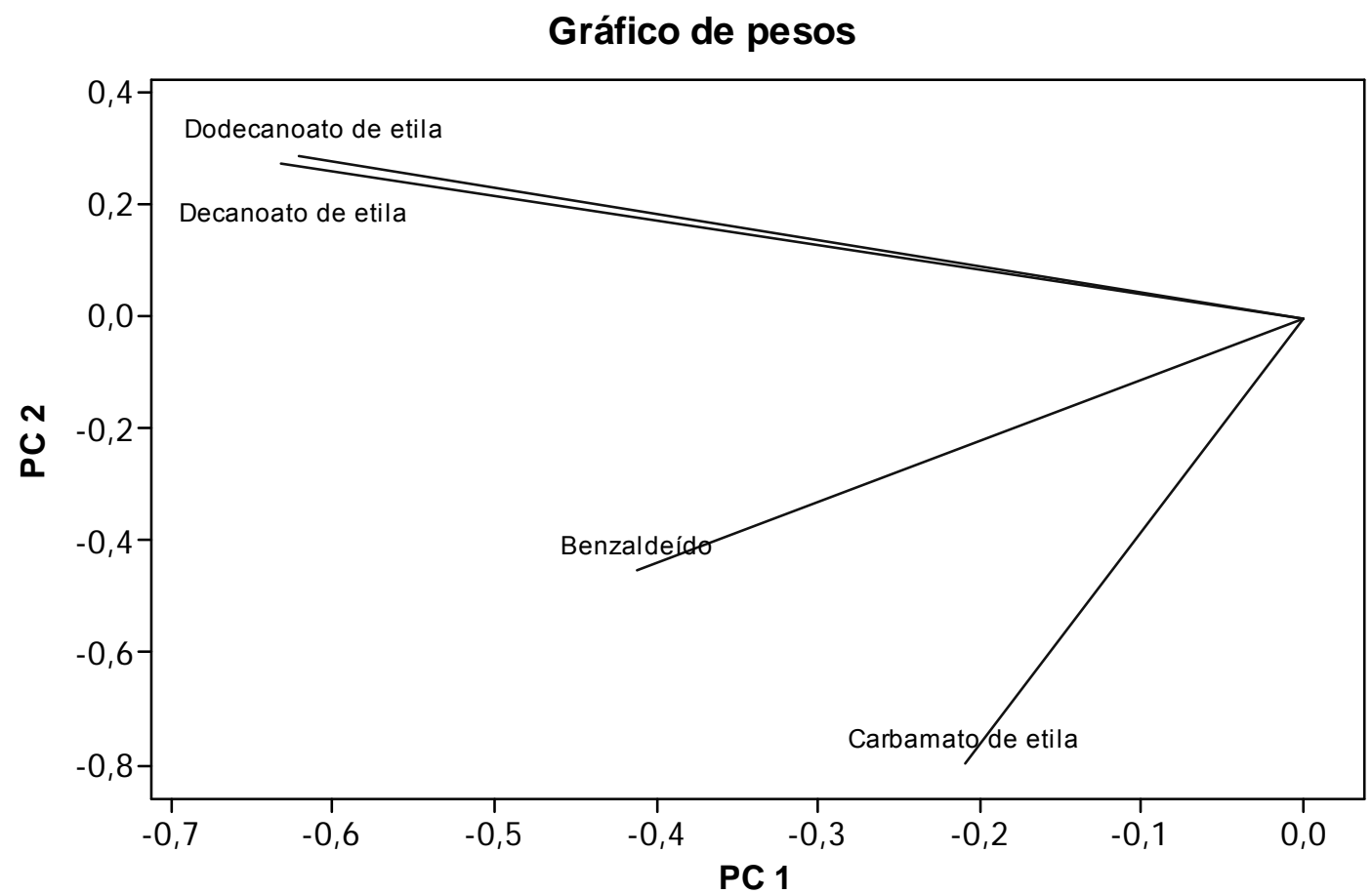

Figura 25. Gráfico de pesos obtido para as 82 amostras de aguardente de cana utilizando o novo banco de dados (107 amostras).

Os analitos utilizados como discriminantes neste trabalho foram importantes na separação, pois são compostos presentes nas amostras de coluna de aço inox em concentrações relativamente superiores, ou seja, eles também estão presentes nas amostras de alambique de cobre, porém em concentrações inferiores.

A Tabela 12 apresenta os valores dos pesos obtidos para cada composto e a somatória dos valores de PC 1 e PC 2. 
Tabela 12: Valores de pesos para cada discriminante químico obtidos na separação PC 1 x PC 2.

\begin{tabular}{cccc}
\hline Compostos & PC 1 & PC 2 & PC 1 + PC 2 \\
\hline Carbamato de etila & $-0,209$ & $-0,798$ & 1,01 \\
Benzaldeído & $-0,412$ & $-0,453$ & 0,865 \\
Decanoato de etila & $-0,622$ & $-0,289$ & 0,911 \\
Dodecanoato de etila & $-0,633$ & 0,274 & 0,907 \\
\hline
\end{tabular}

\subsubsection{Regressão por mínimos quadrados parciais}

Os mesmos discriminantes que foram utilizados na análise de componentes principais foram também utilizados na regressão por mínimos quadrados parciais. Na PLS foi utilizada a validação cruzada com retirada de uma amostra por análise e o banco de dados analíticos foi autoescalado.

A Figura 26 mostra o gráfico de pontuação obtido na separação por PLS considerando PC 1 e PC 2. A amostra 51 não foi classificada corretamente em seu grupo de origem devido a sua concentração de carbamato de etila possuir um valor elevado quando comparado com as amostras de seu grupo.

A soma dos valores obtidos para PC 1 (49,5\%) e PC 2 (28,9\%) apresentam uma explicação de 78,4 \% do total da variância do banco de dados. Este valor está muito próximo do valor obtido na análise pela PCA $(81,0 \%)$. 


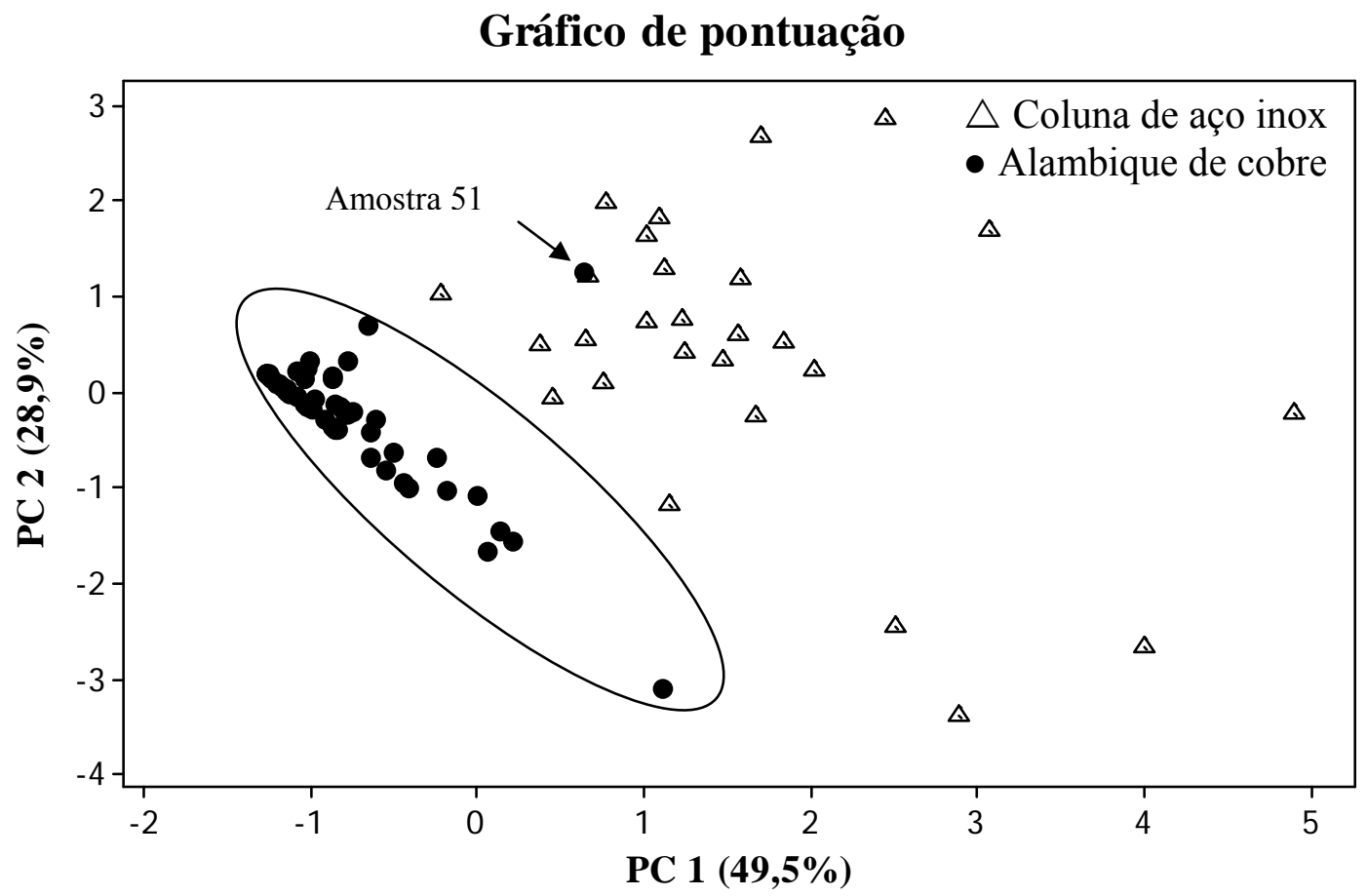

Figura 26. Gráfico de pontuação entre as componentes 1 e 2 da PLS.

Assim como na PCA observa-se na Figura 26 a existência de dois grupos, um representando as amostras de aguardente de cana destiladas em alambique de cobre (grupo •) e o outro representando as amostras destiladas em coluna de aço inox (grupo $\triangle$ ). As amostras de aguardente de cana de alambique de cobre estão mais agrupadas do que as amostras de aguardente de cana de coluna de aço inox.

Os compostos mais importantes para cada grupo estão apresentados no gráfico de pesos (Figura 27). Do mesmo modo que a PCA, os analitos utilizados como discriminantes neste trabalho foram importantes na separação, pois são compostos presentes nas amostras de coluna de aço inox em concentrações relativamente superiores. 
Gráfico de pesos

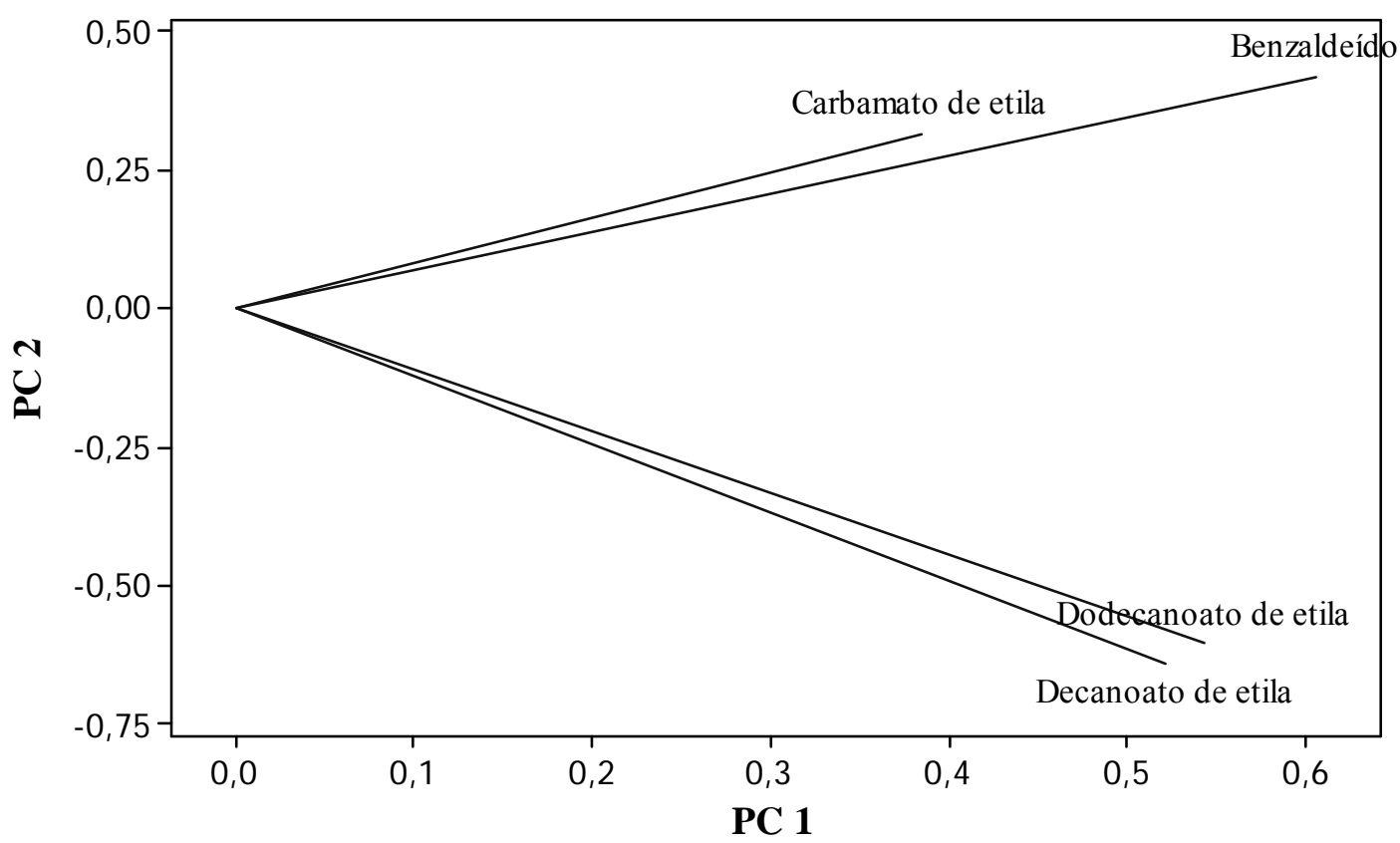

Figura 27. Gráfico de pesos das componentes 1 e 2 da PLS.

\subsubsection{Análise discriminante linear}

A análise discriminante linear é uma ferramenta extremamente poderosa em estudos de discriminação entre grupos, principalmente quando possuímos uma quantidade reduzida de grupos (dois ou três grupos).

Os resultados obtidos na separação entre os dois grupos de aguardentes de cana (alambique de cobre $x$ coluna) são apresentados na Tabela 13 (criação do modelo) e na Tabela 14 (validação cruzada do modelo).

A Tabela 13 apresenta o modelo com as 82 amostras de aguardente de cana. Observa-se que apenas uma amostra de alambique e uma amostra de coluna foram 
classificadas no grupo errado. A porcentagem total de acerto do modelo criado é de $97,6 \%$.

Tabela 13: Classificação das amostras no modelo da LDA.

Modelo

Alambique

Coluna

Total

Total corrreto

Porcentagem (\%)

Total de amostras

Total corrretas

$\%$ Correta

\section{Grupo Verdadeiro}

Alambique Coluna

54

1

26

55

27

54

26

98,2

96,7

Após a criação do modelo foi realizada a validação cruzada do mesmo. Validação cruzada é o método de particionar o banco de dados utilizado na criação do modelo em subgrupos menores para serem testados no modelo criado. Este teste tem como objetivo verificar quão bom é a capacidade do método em predizer o grupo a que pertence uma amostra aleatória do modelo.

Observa-se na Tabela 14 que as porcentagens de acerto do grupo das amostras destiladas em coluna e a porcentagem de acerto total diminuíram com relação aos valores descritos na Tabela 13. Este comportamento é esperado, uma vez que o modelo com validação cruzada torna-se muito mais robusto devido ao teste efetuado com cada amostra do modelo no momento da validação. 
Tabela 14: Classificação das amostras após a validação cruzada no modelo da LDA.

\begin{tabular}{ccc}
\hline Modelo & \multicolumn{2}{c}{ Grupo Verdadeiro } \\
\cline { 2 - 3 } Alambique & Alambique & Coluna \\
Coluna & 54 & 3 \\
Total & 1 & 24 \\
Total corrreto & 55 & 27 \\
Porcentagem (\%) & 54 & 24 \\
& 98,2 & \\
Total de amostras & & \\
Total corrretas & 82 & \\
\% Correta & 78 & \\
\hline
\end{tabular}

A porcentagem de acerto do grupo das amostras destiladas em alambique foi de 98,2 \% o mesmo valor encontrado na criação do modelo. Já para as amostras destiladas em coluna a porcentagem de acerto foi de $88,9 \%$, sendo que a porcentagem total acumulada da validação cruzada foi de $95,1 \%$.

A etapa de predição (etapa onde amostras que não pertencem ao banco de dados são analisadas para testar a confiança do modelo) do modelo não foi realizada, pois as concentrações de carbamato de etila e benzaldeído não foram calculadas para as 136 amostras, apenas 107. Entretanto os valores de porcentagem de acerto do modelo e da validação cruzada do modelo estão acima de $95 \%$ e indicam que esta análise é extremamente poderosa para distinção entre as amostras produzidas em alambique de cobre e em coluna de aço inox. 


\subsubsection{Sobre a presença dos compostos considerados na separação das amostras submetidas a diferentes processos de destilação}

Em todas as análises quimiométricas realizadas (PCA, PLS e LDA) foram utilizados os mesmos discriminantes, os quais são: carbamato de etila, benzaldeído, decanoato de etila e dodecanoato de etila. Estes compostos são característicos de aguardentes de cana destiladas em colunas de aço inox.

O carbamato de etila é um composto formado durante a fermentação do vinho, e quando este é destilado em colunas de aço inoxidável a concentração de carbamato de etila encontrada é superior à concentração deste composto do que quando a aguardente de cana é destilada em alambiques de cobre ${ }^{59}$.

A Figura 28 mostra que a maioria das amostras destiladas em alambiques de cobre apresenta teores de carbamato de etila entre 0,00 e $0,05 \mathrm{mg} 100 \mathrm{~mL}^{-1} \mathrm{de}$ álcool anidro e que apenas duas amostras apresentaram teores acima de 0,05 mg $100 \mathrm{~mL}^{-1}$ de álcool anidro. 


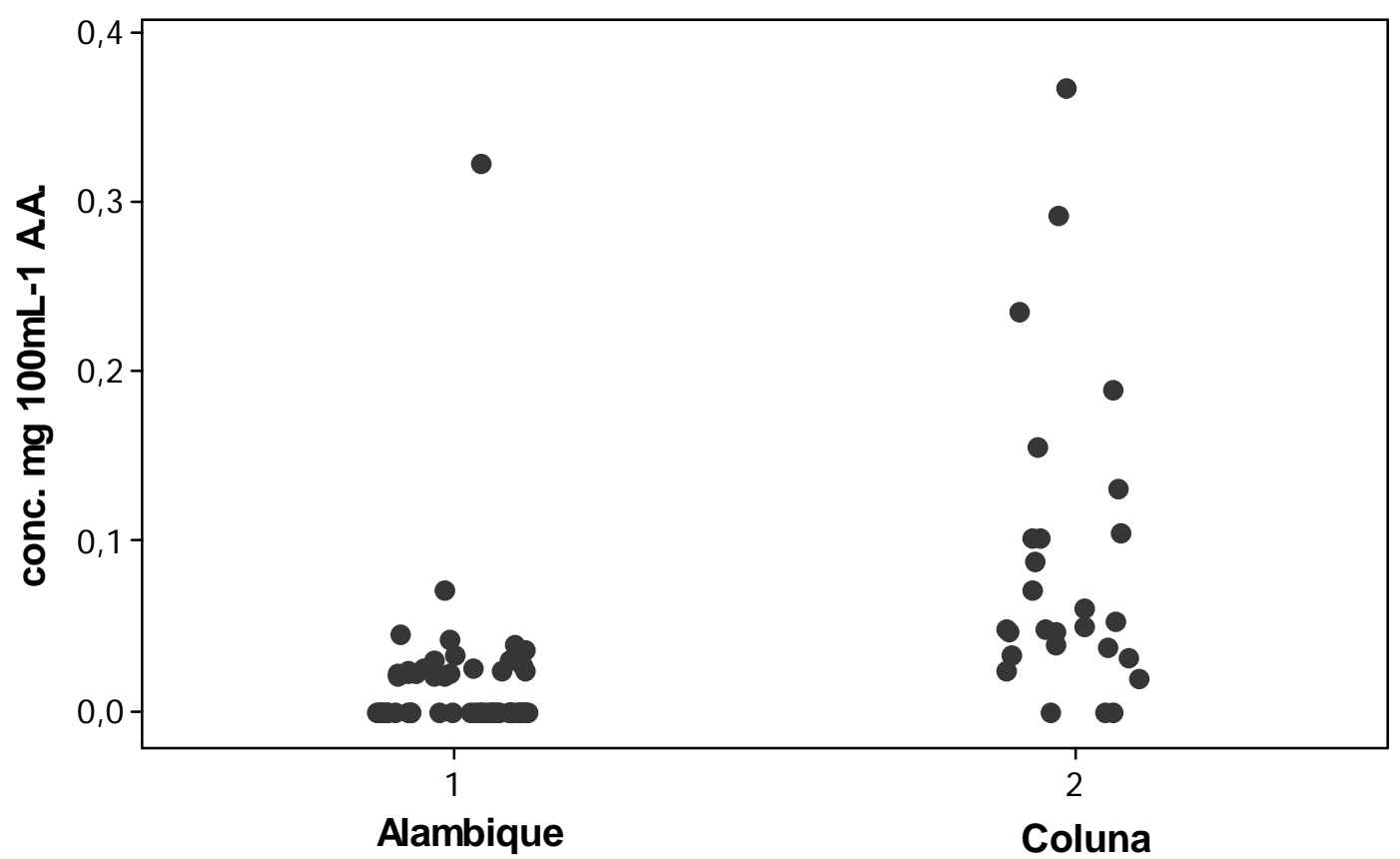

Figura 28. Concentração de carbamato de etila nas aguardentes de cana destiladas em alambiques de cobre e colunas de aço inox.

Todas as amostras destiladas em colunas de aço inox acusaram a presença de benzaldeído, enquanto que várias amostras destiladas em alambiques de cobre apresentaram valor de concentração abaixo do limite detectado pela metodologia ( $L D=0,002 \mathrm{mg} 100 \mathrm{~mL}^{-1}$ de álcool anidro). Isto pode ser explicado pelo fato de que o benzaldeído é um composto com ponto de ebulição relativamente elevado $\left(P . E .=178^{\circ} \mathrm{C}\right)$ e estará presente na chamada "cauda" da cachaça.

O processo de destilação em alambiques é característico pela retirada da cabeça (compostos com baixo ponto de ebulição) e da cauda (compostos com alto ponto de ebulição) da aguardente. Já as aguardentes destiladas em coluna não são fracionadas, ou seja, não há retirada da cabeça ou da cauda da aguardente, e o benzaldeído pode ser assim arrastado pelo vapor hidroalcoólico. 
A Figura 29 mostra a concentração de benzaldeído para as amostras de aguardente de cana que foram destiladas em alambiques de cobre e colunas de aço inox.

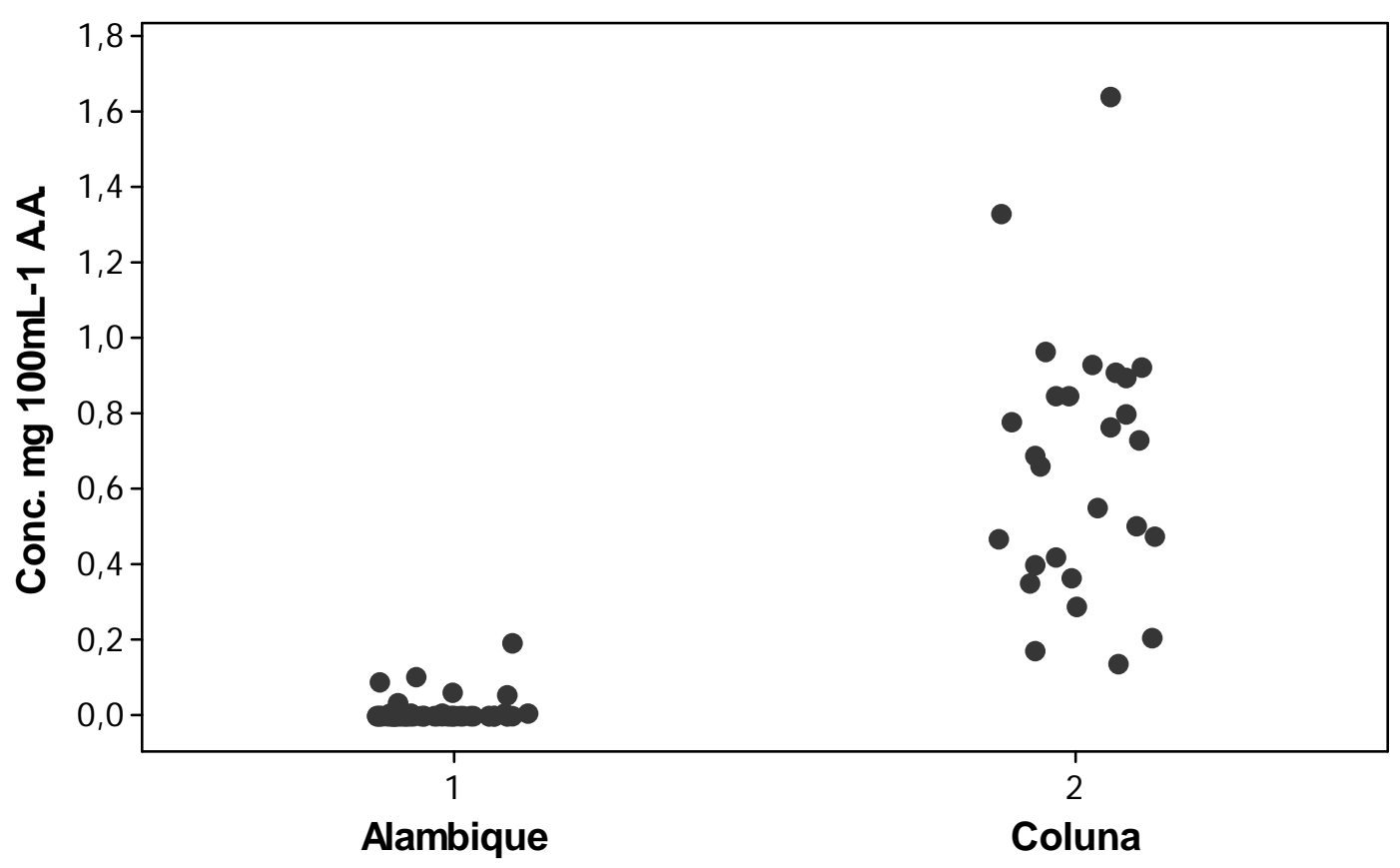

Figura 29. Concentração de benzaldeído nas aguardentes de cana destiladas em alambiques de cobre e colunas de aço inox.

Assim como o benzaldeído, o decanoato de etila e o dodecanoato de etila são compostos com ponto de ebulição relativamente elevados, $241,5^{\circ} \mathrm{C}$ e $269^{\circ} \mathrm{C}$ respectivamente. Portanto, suas concentrações elevadas nas amostras de aguardente de cana que foram destiladas em colunas de aço inox podem ser explicadas de forma semelhante à descrita para o benzaldeído.

As Figuras 30 e 31 apresentam as concentrações de decanoato de etila e dodecanoato de etila para as amostras de aguardente de cana que foram destiladas em alambiques de cobre e colunas de aço inox. 


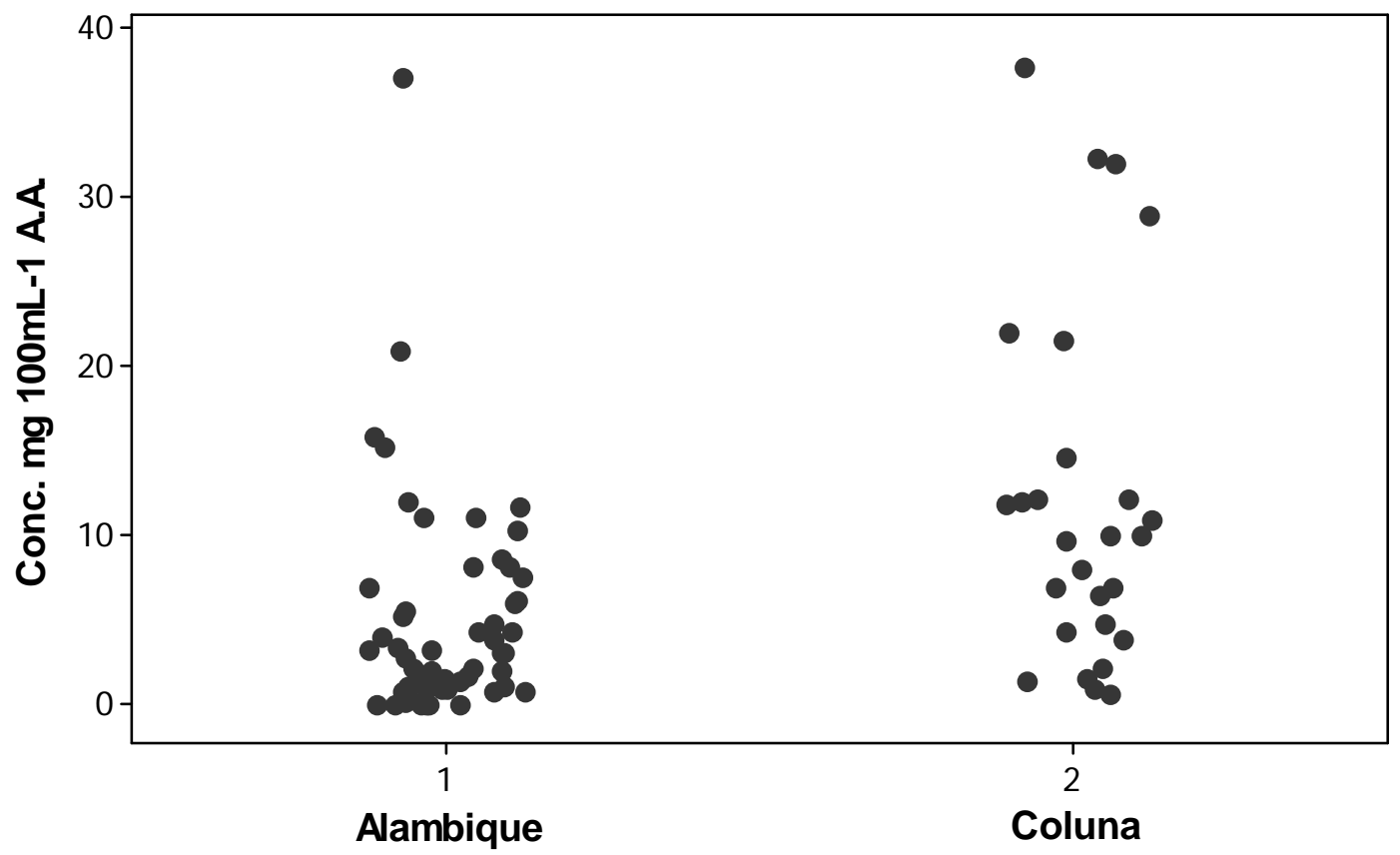

Figura 30. Concentração de decanoato de etila nas aguardentes de cana destiladas em alambiques de cobre e colunas de aço inox.

Pode-se observar na Figura $\mathbf{3 0}$ que as amostras de aguardente de cana destiladas em colunas de aço inox apresentam uma maior concentração de decanoato de etila com teores entre 0,683 a $37,7 \mathrm{mg} 100 \mathrm{~mL}^{-1}$ de álcool anidro. Enquanto que a maioria das amostras de aguardente de cana destiladas em alambiques de cobre apresentam teores de decanoato de etila entre 0,00 e $15,9 \mathrm{mg} 100 \mathrm{~mL}^{-1}$ de álcool anidro e que apenas duas amostras apresentaram teores acima $20,0 \mathrm{mg} 100 \mathrm{~mL}^{-1}$ de álcool anidro. 


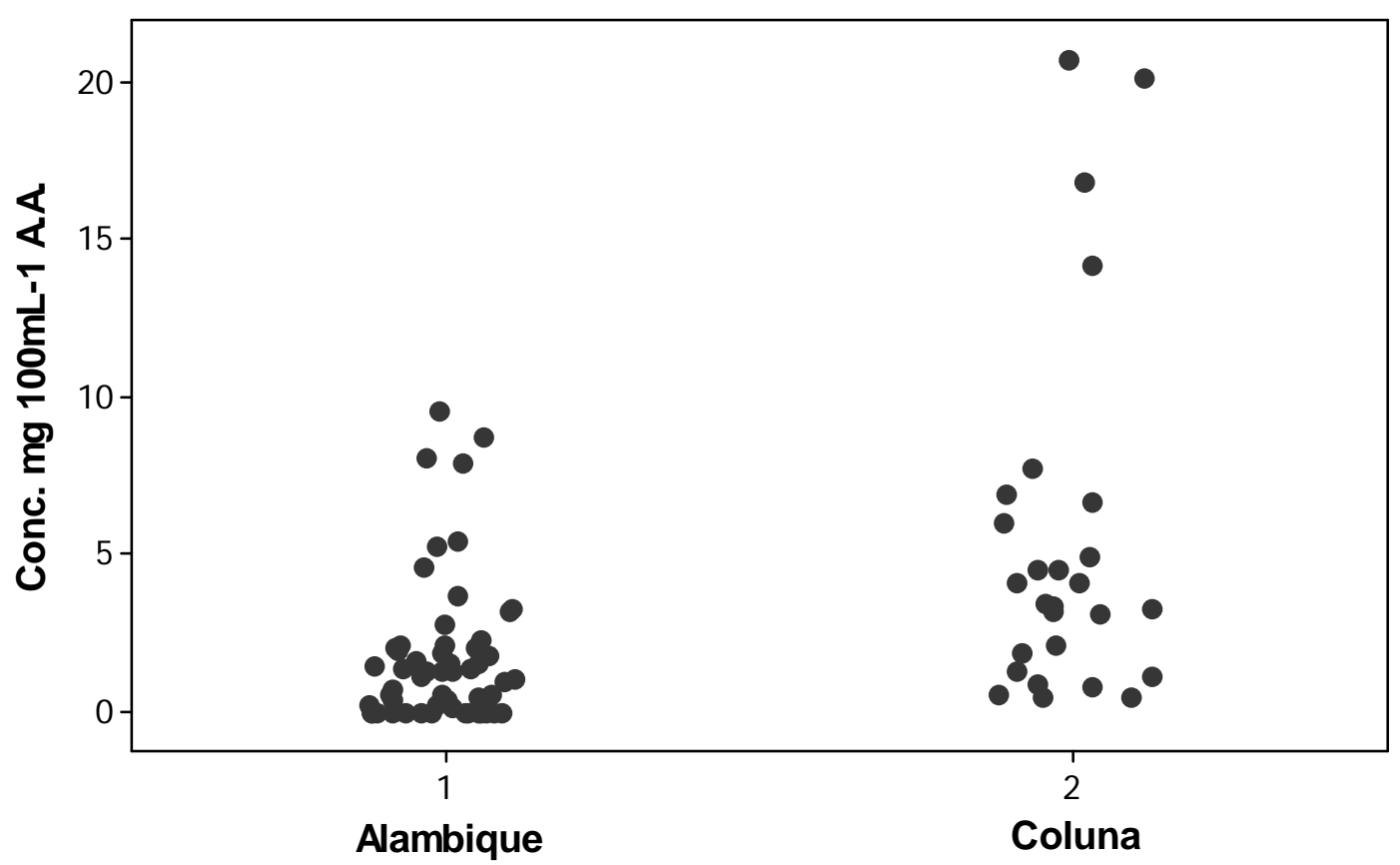

Figura 31. Concentração de dodecanoato de etila nas aguardentes de cana destiladas em alambiques de cobre e colunas de aço inox.

Igualmente ao decanoato de etila, observa-se na Figura 31 que o dodecanoato de etila está presente em teores relativamente elevados nas amostras de aguardente de cana destiladas em colunas de aço inox quando comparado às amostras que foram destiladas em alambiques de cobre. A maioria das amostras destiladas em alambiques de cobre apresenta teores de dodecanoato de etila entre 0,00 e $5,50 \mathrm{mg} 100 \mathrm{~mL}^{-1}$ de álcool anidro sendo que apenas quatro amostras apresentaram teores acima de 5,50 mg $100 \mathrm{~mL}^{-1}$ de álcool anidro. 


\subsection{Concentrações dos ésteres nas amostras de cachaça comercial}

A Tabela 15 lista os valores para a média, mediana, valor máximo e valor mínimo da concentração para as 21 amostras de cachaça comercial analisadas.

O nonanoato de etila e o octanoato de isoamila, cujos limites de detecção são 0,0457 e 0,0258 $\mathrm{mg} \mathrm{L}^{-1}$ respectivamente, não foram detectados em nenhuma amostra de cachaça comercial.

Tabela 15: Valores para a média, mediana, valor máximo e valor mínimo de concentração para os ésteres nas amostras de cachaça comercial.

\begin{tabular}{ccccc}
\hline Compostos & \multicolumn{4}{c}{ Cachaça comercial * } \\
\cline { 2 - 5 } Acetato de etila & Média & Mediana & V. máx. & V. mín. \\
Butanoato de etila & 37,5 & 22,0 & 97,6 & 5,20 \\
Hexanoato de etila & 0,227 & 0,166 & 0,740 & 0,0818 \\
Lactato de etila & 13,9 & 9,23 & 59,4 & 3,08 \\
Octanoato de etila & 0,491 & 0,400 & 1,32 & 0,151 \\
Nonanoato de etila & $<$ LD & $<$ LD & $<$ LD & $<$ <D \\
Decanoato de etila & 1,70 & 0,747 & 13,5 & 0,486 \\
Octanoato de isoamila & <LD & <LD & $<$ LD & $<$ <D \\
Dodecanoato de etila & 0,593 & 0,397 & 2,14 & 0,191 \\
\hline
\end{tabular}

* Concentração em mg $100 \mathrm{~mL}^{-1}$ de álcool anidro.

Assim como as amostras coletadas diretamente junto aos produtores, as cachaças comerciais apresentaram o acetato de etila como o principal éster. O lactato de etila também se confirmou como o segundo éster mais representativo na cachaça reafirmando a necessidade de se monitorar este composto juntamente com o acetato de etila na determinação de ésteres totais. Ressalta-se que as amostras 
de cachaça comercial são provenientes de diversos estados do Brasil (ANEXO G), reafirmando a tendência do lactato de etila estar sempre presente.

Na Tabela 16 são apresentadas as concentrações dos ésteres obtidas para as amostras de cachaça. 
Tabela 16: Concentrações dos ésteres nas amostras de cachaça comercial (mg $100 \mathrm{~mL}^{-1}$ de álcool anidro).

\begin{tabular}{|c|c|c|c|c|c|c|c|c|c|}
\hline Amostras & $\begin{array}{l}\text { Acetato } \\
\text { de etila }\end{array}$ & $\begin{array}{c}\text { Butanoato } \\
\text { de etila }\end{array}$ & $\begin{array}{l}\text { Hexanoato } \\
\text { de etila }\end{array}$ & $\begin{array}{l}\text { Lactato } \\
\text { de etila }\end{array}$ & $\begin{array}{c}\text { Octanoato } \\
\text { de etila }\end{array}$ & $\begin{array}{c}\text { Nonanoato } \\
\text { de etila }\end{array}$ & $\begin{array}{c}\text { Decanoato } \\
\text { de etila }\end{array}$ & $\begin{array}{l}\text { Octanoato } \\
\text { de isoamila }\end{array}$ & $\begin{array}{c}\text { Dodecanoato } \\
\text { de etila }\end{array}$ \\
\hline Amostra 02 & 20,4 & $<$ LD & 0,0653 & 14,4 & 0,238 & $<L D$ & 0,604 & $<$ LD & 0,260 \\
\hline Amostra 03 & 97,6 & 0,124 & 0,118 & 4,13 & 0,529 & $<L D$ & 13,5 & $<L D$ & 0,762 \\
\hline Amostra 04 & 13,3 & $<L D$ & $<L D$ & 9,49 & 0,282 & $<\mathrm{LD}$ & 1,08 & $<\mathrm{LD}$ & 0,664 \\
\hline Amostra 05 & 61,2 & $<$ LD & 0,167 & 4,04 & 0,794 & $<\mathrm{LD}$ & 1,76 & $<\mathrm{LD}$ & 0,654 \\
\hline Amostra 07 & 9,76 & $<L D$ & 0,125 & 10,0 & 0,416 & $<$ LD & 0,638 & $<L D$ & 0,398 \\
\hline Amostra 08 & 38,2 & 0,0880 & 0,196 & 6,73 & 0,620 & $<\mathrm{LD}$ & 0,747 & $<\mathrm{LD}$ & 0,500 \\
\hline Amostra 09 & 22,0 & 0,740 & 0,0848 & 3,08 & 0,375 & $<L D$ & 0,703 & $<$ LD & 0,191 \\
\hline Amostra 10 & 5,21 & $<L D$ & $<$ LD & 3,67 & 0,400 & $<L D$ & 1,72 & $<\mathrm{LD}$ & 0,667 \\
\hline Amostra 14 & 37,2 & $<\mathrm{LD}$ & $<\mathrm{LD}$ & 9,23 & 0,160 & $<\mathrm{LD}$ & 0,569 & $<\mathrm{LD}$ & 0,349 \\
\hline Amostra 15 & 90,5 & $<$ LD & 0,0855 & 24,5 & 0,264 & $<\mathrm{LD}$ & 0,581 & $<\mathrm{LD}$ & 0,321 \\
\hline Amostra 16 & 65,9 & 0,0818 & 0,114 & 11,8 & 0,503 & $<\mathrm{LD}$ & 0,741 & $<L D$ & 0,231 \\
\hline Amostra 17 & 33,0 & 0,203 & 0,348 & 6,20 & 1,16 & $<$ LD & 2,63 & $<\mathrm{LD}$ & 1,41 \\
\hline
\end{tabular}


Tabela 16: Continuação.

\begin{tabular}{|c|c|c|c|c|c|c|c|c|c|}
\hline Amostras & $\begin{array}{l}\text { Acetato } \\
\text { de etila }\end{array}$ & $\begin{array}{c}\text { Butanoato } \\
\text { de etila }\end{array}$ & $\begin{array}{c}\text { Hexanoato } \\
\text { de etila }\end{array}$ & $\begin{array}{l}\text { Lactato } \\
\text { de etila }\end{array}$ & $\begin{array}{c}\text { Octanoato } \\
\text { de etila }\end{array}$ & $\begin{array}{c}\text { Nonanoato } \\
\text { de etila }\end{array}$ & $\begin{array}{c}\text { Decanoato } \\
\text { de etila }\end{array}$ & $\begin{array}{c}\text { Octanoato } \\
\text { de isoamila }\end{array}$ & $\begin{array}{c}\text { Dodecanoato } \\
\text { de etila }\end{array}$ \\
\hline Amostra 19 & 11,6 & $<$ LD & $<$ LD & 55,5 & 0,151 & $<\mathrm{LD}$ & 0,626 & $<L D$ & 0,356 \\
\hline Amostra 20 & 12,6 & $<$ LD & $<$ LD & 7,96 & 0,207 & $<$ LD & 0,975 & $<$ LD & 0,640 \\
\hline Amostra 21 & 86,0 & 0,146 & 0,583 & 59,4 & 0,970 & $<$ LD & 1,03 & $<$ LD & 0,359 \\
\hline
\end{tabular}

<LD: valores abaixo do limite de detecção. 
A Tabela 17 apresenta os valores da média e da mediana das concentrações dos ésteres nas amostras de aguardente de cana coletadas na origem e nas amostras de cachaça comercial.

Tabela 17: Concentrações relativas dos ésteres nas amostras de aguardente de cana coletadas na origem e cachaça comercial.

\begin{tabular}{ccccccc}
\hline Compostos & \multicolumn{2}{c}{$\begin{array}{c}\text { Aguardente } \\
\text { de cana }\end{array}$} & \multicolumn{2}{c}{$\begin{array}{c}\text { Cachaça } \\
\text { comercial }\end{array}$} & $\begin{array}{c}\text { DP * } \\
\text { Médias }\end{array}$ & $\begin{array}{c}\text { DP * } \\
\text { Medianas }\end{array}$ \\
\cline { 2 - 6 } Acetato de etila & 48,7 & 22,6 & 37,5 & 22,0 & 13,1 & 8,78 \\
Butanoato de etila & 0,244 & 0,136 & 0,227 & 0,166 & 0,0581 & 0,0464 \\
Hexanoato de etila & 0,180 & 0,116 & 0,187 & 0,142 & 0,0391 & 0,0359 \\
Lactato de etila & 27,1 & 8,32 & 13,9 & 9,23 & 9,64 & 2,99 \\
Octanoato de etila & 0,559 & 0,325 & 0,491 & 0,400 & 0,120 & 0,0831 \\
Nonanoato de etila & 0,0633 & 0,0534 & $<L D$ & $<L D$ & - & - \\
Decanoato de etila & 1,35 & 0,801 & 1,70 & 0,747 & 0,453 & 0,535 \\
Octanoato de isoamila & 0,0599 & 0,0424 & $<L D$ & $<L D$ & - & - \\
Dodecanoato de etila & 0,604 & 0,344 & 0,593 & 0,397 & 0,147 & 0,131 \\
\hline
\end{tabular}

* Desvio padrão

Obs. Todas as concentrações estão em mg $100 \mathrm{~mL}^{-1}$ de álcool anidro.

Nota-se que houve pouca diferença entre os valores da média e da mediana das concentrações dos ésteres entre as amostras de aguardente de cana e as amostras de cachaça comercial.

A Tabela 18 lista os valores da concentração total de ésteres, teor alcoólico e o sistema de destilação utilizado para as amostras de cachaça comercial. 
Tabela 18: Valores de concentração de ésteres totais, graduação alcoólica e sistema de destilação utilizado para as amostras de cachaça comercial.

\begin{tabular}{|c|c|c|c|}
\hline Amostras & Ésteres totais $^{a}$ & Teor alcoólico (GL) & Sistema de destilação \\
\hline Amostra 01 & 31,1 & 42,0 & Coluna de aço inoxidável \\
\hline Amostra 02 & 35,9 & 45,0 & Alambique de cobre \\
\hline Amostra 03 & 117 & 45,0 & Alambique de cobre \\
\hline Amostra 04 & 24,8 & 39,0 & Alambique de cobre \\
\hline Amostra 05 & 68,7 & 41,0 & Alambique de cobre \\
\hline Amostra 06 & 37,8 & 43,5 & Alambique de cobre \\
\hline Amostra 07 & 21,3 & 45,0 & Alambique de cobre \\
\hline Amostra 08 & 47,1 & 45,0 & Alambique misto \\
\hline Amostra 09 & 27,2 & 40,0 & Alambique misto \\
\hline Amostra 10 & 11,7 & 39,0 & Alambique de cobre \\
\hline Amostra 11 & 30,0 & 39,0 & Alambique de cobre \\
\hline Amostra 12 & 107 & 43,0 & Alambique de cobre \\
\hline Amostra 13 & 24,4 & 39,0 & Alambique de cobre \\
\hline Amostra 14 & 47,5 & 39,0 & Alambique de cobre \\
\hline Amostra 15 & 116 & 42,0 & Alambique de cobre \\
\hline Amostra 16 & 79,3 & 39,0 & Alambique de cobre \\
\hline Amostra 17 & 44,9 & 40,0 & Alambique de cobre \\
\hline Amostra 18 & 32,0 & 40,0 & Alambique de cobre \\
\hline Amostra 19 & 68,2 & 39,5 & Alambique de cobre \\
\hline Amostra 20 & 22,4 & 50,0 & Alambique de cobre \\
\hline Amostra 21 & 149 & 36,5 & Alambique de cobre \\
\hline
\end{tabular}

$\mathrm{a}=$ Concentração em $\mathrm{mg} 100 \mathrm{~mL}^{-1}$ de álcool anidro.

b = Graduação alcoólica em graus GL (grau Gay-Lussac \% v/v álcool etílico).

A Figura 32 mostra um histograma da mediana da concentração total de ésteres em mg $100 \mathrm{~mL}^{-1}$ de álcool anidro de acordo com o sistema de destilação utilizado para as amostras de cachaça comercial. 


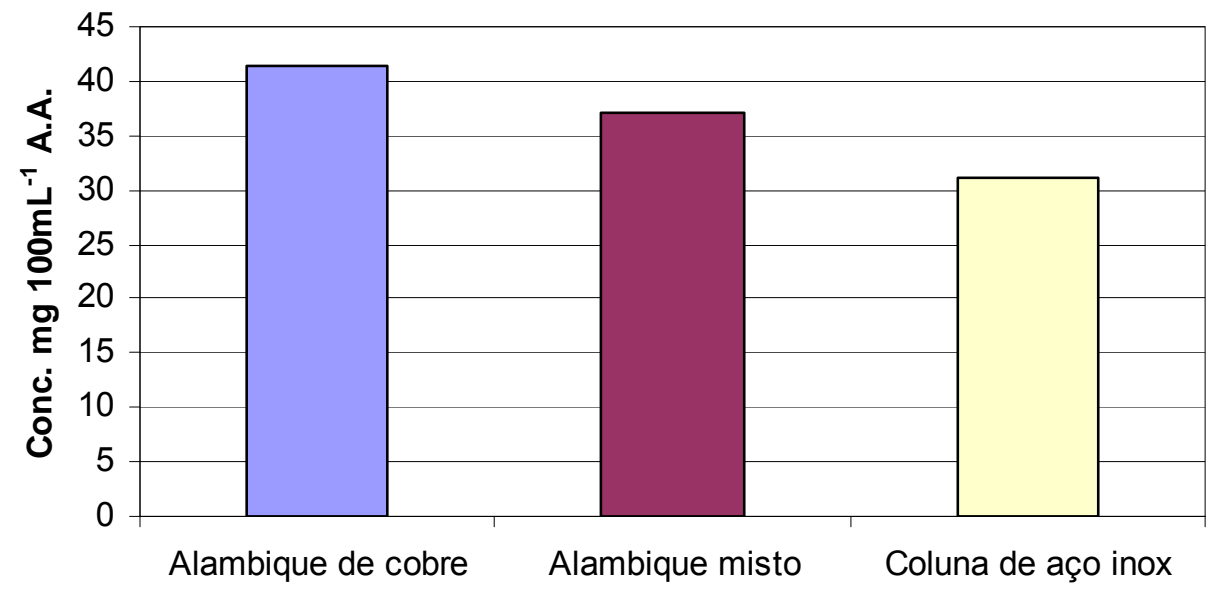

Tipo de destilador

Figura 32. Histograma da mediana da concentração total de ésteres das amostras de cachaça comercial de acordo com o sistema de destilação utilizado.

Observa-se na Figura 32 que as amostras de cachaça comercial que foram destiladas em alambiques de cobre apresentaram uma concentração total de ésteres maior que as das amostras destiladas em alambiques misto e em colunas de aço inox. Entretanto, o banco de dados das amostras de cachaça comercial não é representativo se comparado ao banco de dados das amostras de aguardente cana coletadas na origem, pois o banco de dados das amostras de cachaça comercial possui apenas uma amostra que foi destilada em coluna de aço inox e duas destiladas em alambiques misto.

A Figura 33 mostra um histograma da mediana da concentração total de ésteres em mg $100 \mathrm{~mL}^{-1}$ de álcool anidro para as amostras de cachaça comercial brancas, descansadas e envelhecidas. 


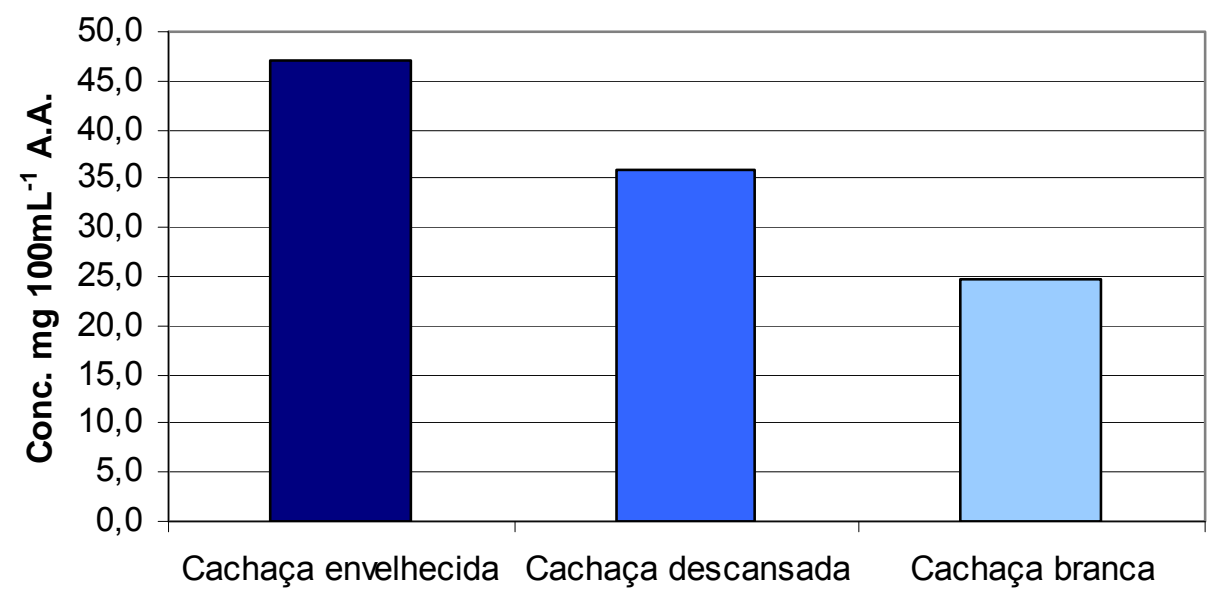

Tempo de envelhecimento

Figura 33. Histograma da mediana da concentração total de ésteres das amostras de cachaça comercial de acordo com o tempo de envelhecimento.

Nota-se na Figura 33 que as amostras que foram submetidas ao processo de envelhecimento (acima de um ano) apresentam uma concentração total de ésteres superior às amostras descansadas (entre zero e um ano) e às amostras brancas (sem tempo de envelhecimento algum). Vale ressaltar que a presença de ésteres etílicos em bebidas destiladas está relacionada ao processo de fermentação e não ao envelhecimento ${ }^{26}$. O banco de dados para as amostras de cachaça comercial não é representativo, pois possuí apenas três amostras brancas e cinco descansadas. A maneira correta de se avaliar este dado seria analisar uma amostra (mesmo caldo) que foi submetida ao mesmo processo de fermentação e destilação, e depois descansada e envelhecida.

Nenhuma amostra de cachaça comercial analisada ultrapassou o limite máximo exigido pela legislação brasileira no que se refere à concentração total de ésteres. 


\subsection{Concentrações dos ésteres nas amostras de rum e uísque comercial}

A Tabela 19 lista os valores para a média, mediana, valor máximo e valor mínimo de concentração dos ésteres para as 10 amostras de rum comercial analisadas e a Tabela 20 lista os valores para a média, mediana, valor máximo e valor mínimo de concentração dos ésteres para as 10 amostras de uísque comercial analisadas.

O nonanoato de etila e o octanoato de isoamila, cujos limites de detecção são 0,0457 e $0,0258 \mathrm{mg} \mathrm{L}^{-1}$ respectivamente, não foram detectados em nenhuma amostra de rum e uísque.

Tabela 19: Valores para a média, mediana, valor máximo e valor mínimo de concentração para os ésteres nas amostras de rum comercial.

\begin{tabular}{ccccc}
\hline Compostos & \multicolumn{4}{c}{ Rum comercial * } \\
\cline { 2 - 5 } Acetato de etila & Média & Mediana & V. máx. & V. mín. \\
Butanoato de etila & 41,3 & 25,4 & 124 & 2,57 \\
Hexanoato de etila & 0,374 & 0,396 & 0,412 & 0,313 \\
Lactato de etila & 6,340 & 0,240 & 0,262 & 0,218 \\
Octanoato de etila & 0,642 & 5,11 & 11,2 & 2,86 \\
Nonanoato de etila & $<$ LD & $<, 642$ & 1,30 & 0,370 \\
Decanoato de etila & 0,828 & 0,671 & 1,86 & 0,370 \\
Octanoato de isoamila & $<$ LD & $<$ LD & $<$ LD & $<$ LD \\
Dodecanoato de etila & 0,476 & 0,476 & 0,476 & 0,476 \\
\hline
\end{tabular}

* Concentrações em mg $100 \mathrm{~mL}^{-1}$ de álcool anidro. 
Tabela 20: Valores para a média, mediana, valor máximo e valor mínimo de concentração para os ésteres nas amostras de uísque comercial.

\begin{tabular}{ccccc}
\hline Compostos & \multicolumn{4}{c}{ Uísque comercial * } \\
\cline { 2 - 5 } Acetato de etila & Média & Mediana & V. máx. & V. mín. \\
Butanoato de etila & 0,144 & 0,125 & 0,240 & 0,067 \\
Hexanoato de etila & 0,340 & 0,250 & 0,805 & 0,114 \\
Lactato de etila & 2,02 & 1,94 & 3,00 & 1,04 \\
Octanoato de etila & 1,85 & 1,07 & 4,30 & 0,393 \\
Nonanoato de etila & $<$ LD & $<$ LD & $<$ LD & $<$ LD \\
Decanoato de etila & 3,42 & 2,60 & 7,49 & 0,729 \\
Octanoato de isoamila & $<$ LD & $<$ LD & $<$ LD & $<$ LD \\
Dodecanoato de etila & 1,98 & 1,84 & 4,63 & 0,199 \\
\hline
\end{tabular}

* Concentração em mg $100 \mathrm{~mL}^{-1}$ de álcool anidro.

Na Tabela 21 são apresentadas as concentrações dos ésteres obtidas para as amostras de rum comercial e na Tabela 22 são apresentadas as concentrações dos ésteres obtidas para as amostras de uísque comercial. 
Tabela 21: Concentrações dos ésteres nas amostras de rum comercial (mg $100 \mathrm{~mL}^{-1}$ de álcool anidro).

\begin{tabular}{|c|c|c|c|c|c|c|c|c|c|}
\hline Amostras & $\begin{array}{l}\text { Acetato } \\
\text { de etila }\end{array}$ & $\begin{array}{c}\text { Butanoato } \\
\text { de etila }\end{array}$ & $\begin{array}{c}\text { Hexanoato } \\
\text { de etila }\end{array}$ & $\begin{array}{l}\text { Lactato } \\
\text { de etila }\end{array}$ & $\begin{array}{c}\text { Octanoato } \\
\text { de etila }\end{array}$ & $\begin{array}{c}\text { Nonanoato } \\
\text { de etila }\end{array}$ & $\begin{array}{c}\text { Decanoato } \\
\text { de etila }\end{array}$ & $\begin{array}{l}\text { Octanoato } \\
\text { de isoamila }\end{array}$ & $\begin{array}{c}\text { Dodecanoato } \\
\text { de etila }\end{array}$ \\
\hline Amostra 01 & 2,57 & $<\mathrm{LD}$ & $<\mathrm{LD}$ & $<\mathrm{LD}$ & $<\mathrm{LD}$ & $<\mathrm{LD}$ & $<\mathrm{LD}$ & $<\mathrm{LD}$ & $<\mathrm{LD}$ \\
\hline Amostra 03 & 17,8 & $<$ LD & $<$ LD & $<$ LD & $<$ LD & $<$ LD & $<$ LD & $<$ LD & $<$ LD \\
\hline Amostra 04 & 21,3 & $<$ LD & $<$ LD & $<$ LD & $<\mathrm{LD}$ & $<$ LD & $<$ LD & $<\mathrm{LD}$ & $<\mathrm{LD}$ \\
\hline Amostra 06 & 37,6 & $<\mathrm{LD}$ & $<$ LD & $<$ LD & 0,503 & $<$ LD & $<L D$ & $<\mathrm{LD}$ & $<\mathrm{LD}$ \\
\hline Amostra 07 & 79,8 & 0,396 & 0,262 & 11,2 & 1,30 & $<\mathrm{LD}$ & 1,86 & $<L D$ & 0,476 \\
\hline Amostra 08 & 12,4 & $<$ LD & $<$ LD & $<$ LD & $<$ LD & $<\mathrm{LD}$ & $<L D$ & $<$ LD & $<$ LD \\
\hline Amostra 09 & 67,0 & $<\mathrm{LD}$ & $<$ LD & 5,11 & 0,506 & $<$ LD & 0,671 & $<\mathrm{LD}$ & $<\mathrm{LD}$ \\
\hline
\end{tabular}

<LD: valores abaixo do limite de detecção 
Tabela 22: Concentrações dos ésteres nas amostras de uísque comercial (mg $100 \mathrm{~mL}^{-1}$ de álcool anidro).

\begin{tabular}{|c|c|c|c|c|c|c|c|c|c|}
\hline Amostras & $\begin{array}{l}\text { Acetato } \\
\text { de etila }\end{array}$ & $\begin{array}{c}\text { Butanoato } \\
\text { de etila }\end{array}$ & $\begin{array}{c}\text { Hexanoato } \\
\text { de etila }\end{array}$ & $\begin{array}{l}\text { Lactato } \\
\text { de etila }\end{array}$ & $\begin{array}{c}\text { Octanoato } \\
\text { de etila }\end{array}$ & $\begin{array}{c}\text { Nonanoato } \\
\text { de etila }\end{array}$ & $\begin{array}{c}\text { Decanoato } \\
\text { de etila }\end{array}$ & $\begin{array}{l}\text { Octanoato } \\
\text { de isoamila }\end{array}$ & $\begin{array}{c}\text { Dodecanoato } \\
\text { de etila }\end{array}$ \\
\hline Amostra 01 & 16,4 & 0,0670 & 0,284 & 1,90 & 2,07 & $<\mathrm{LD}$ & 4,00 & $<\mathrm{LD}$ & 1,91 \\
\hline Amostra 03 & 27,3 & 0,125 & 0,210 & 1,04 & 1,06 & $<$ LD & 2,63 & $<L D$ & 1,33 \\
\hline Amostra 04 & 14,1 & $<$ LD & 0,114 & $<$ LD & 0,393 & $<$ LD & 1,01 & $<$ LD & 0,605 \\
\hline Amostra 06 & 18,3 & 0,106 & 0,217 & 1,56 & 1,08 & $<$ LD & 2,56 & $<$ LD & 1,77 \\
\hline Amostra 07 & 23,9 & 0,110 & 0,200 & $<$ LD & 0,795 & $<$ LD & 1,69 & $<$ LD & 0,850 \\
\hline Amostra 08 & 42,6 & 0,198 & 0,642 & 1,98 & 4,30 & $<$ LD & 6,84 & $<\mathrm{LD}$ & 3,02 \\
\hline Amostra 09 & 27,4 & 0,136 & 0,477 & 2,60 & 3,07 & $<$ LD & 4,79 & $<$ LD & 3,28 \\
\hline
\end{tabular}

$<$ LD: valores abaixo do limite de detecção 
A Tabela 23 lista os valores da concentração total de ésteres e a graduação alcoólica para as amostras de rum e uísque comercial.

Tabela 23: Valores de concentração de ésteres totais e graduação alcoólica para as amostras de rum e uísque comercial.

\begin{tabular}{|c|c|c|c|c|}
\hline \multirow[b]{2}{*}{ Amostras } & \multicolumn{2}{|c|}{ Rum } & \multicolumn{2}{|c|}{ Uísque } \\
\hline & Ésteres totais ${ }^{a}$ & $\begin{array}{c}\text { Teor alcoólico } \\
\left({ }^{\circ} \mathrm{GL}\right)^{b}\end{array}$ & Ésteres totais $^{a}$ & $\begin{array}{c}\text { Teor alcoólico } \\
\left({ }^{\circ} \mathrm{GL}\right)^{b}\end{array}$ \\
\hline Amostra 01 & 2,57 & 40,0 & 26,7 & 43,0 \\
\hline Amostra 02 & 128 & 40,0 & 31,7 & 40,0 \\
\hline Amostra 03 & 17,8 & 38,0 & 33,6 & 40,0 \\
\hline Amostra 04 & 21,3 & 38,0 & 16,2 & 40,0 \\
\hline Amostra 05 & 24,3 & 38,0 & 89,0 & 45,0 \\
\hline Amostra 06 & 38,1 & 38,0 & 25,6 & 43,0 \\
\hline Amostra 07 & 95,3 & 40,0 & 27,5 & 40,0 \\
\hline Amostra 08 & 12,4 & 38,0 & 59,5 & 43,0 \\
\hline Amostra 09 & 73,3 & 38,0 & 41,8 & 43,0 \\
\hline Amostra 10 & 27,9 & 38,0 & 56,3 & 43,0 \\
\hline
\end{tabular}

O acetato de etila também é o principal éster presente no rum e no uísque. O lactato de etila também é o segundo éster majoritário presente no rum, porém no uísque este analito encontra-se na mesma ordem de grandeza que os demais ésteres estudados. Esta observação indica a ausência de contaminação por Lactobacillus spp durante o processo de fermentação do uísque. Vale salientar que a produção de uísque corriqueiramente emprega leveduras selecionadas e um estrito controle da contaminação microbiológica do pé de cuba, enquanto que tanto a produção de rum quanto a de cachaça, de um modo geral, utiliza-se de leveduras 
selvagens, não selecionadas, e sem o desejado controle microbiológico do processo.

As amostras de rum envelhecidas apresentaram valores superiores para concentração total de ésteres quando comparadas às amostras ditas brancas, ou seja, que não foram submetidas ao processo de envelhecimento, conforme pode ser observado na Figura 34.

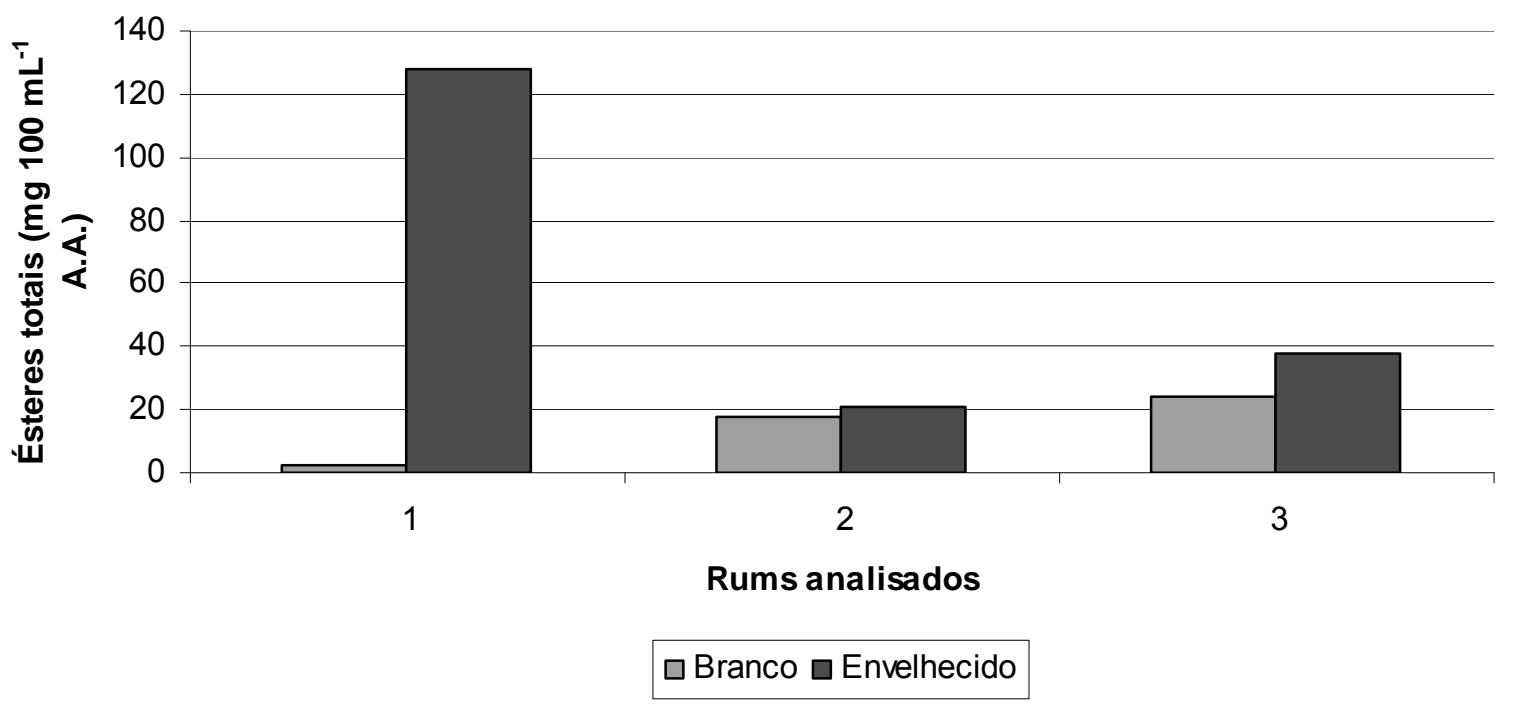

Figura 34. Concentração total de ésteres em amostras de rum branco e rum envelhecido. 1- Havana Silver/Havana 7 anos 2- Montilla Cristal/Montilla Ouro 3Bacardi Branca/Bacardi Oro.

Todas as amostras de rum não envelhecido analisadas continham apenas o acetato de etila dentre todos os ésteres estudados. As amostras envelhecidas apresentaram uma concentração de acetato de etila mais elevada que as amostras brancas. As amostras de rum que foram produzidas no Brasil (Montilla e Bacardi) apresentaram um perfil químico de ésteres "pobre", uma vez que apenas acetato de etila e lactato de etila foram detectados. 
Uma possível causa para a baixa concentração de ésteres nas amostras de rum é que durante o processo de produção da bebida alguns produtores passam o rum por uma coluna de carvão ativado para eliminação de odores indesejáveis e/ou descoloração e durante este processo pode ocorrer a remoção dos ésteres ${ }^{60}$.

A Figura 35 compara a mediana da concentração total de ésteres presente em todas as amostras de cachaça, rum e uísque.

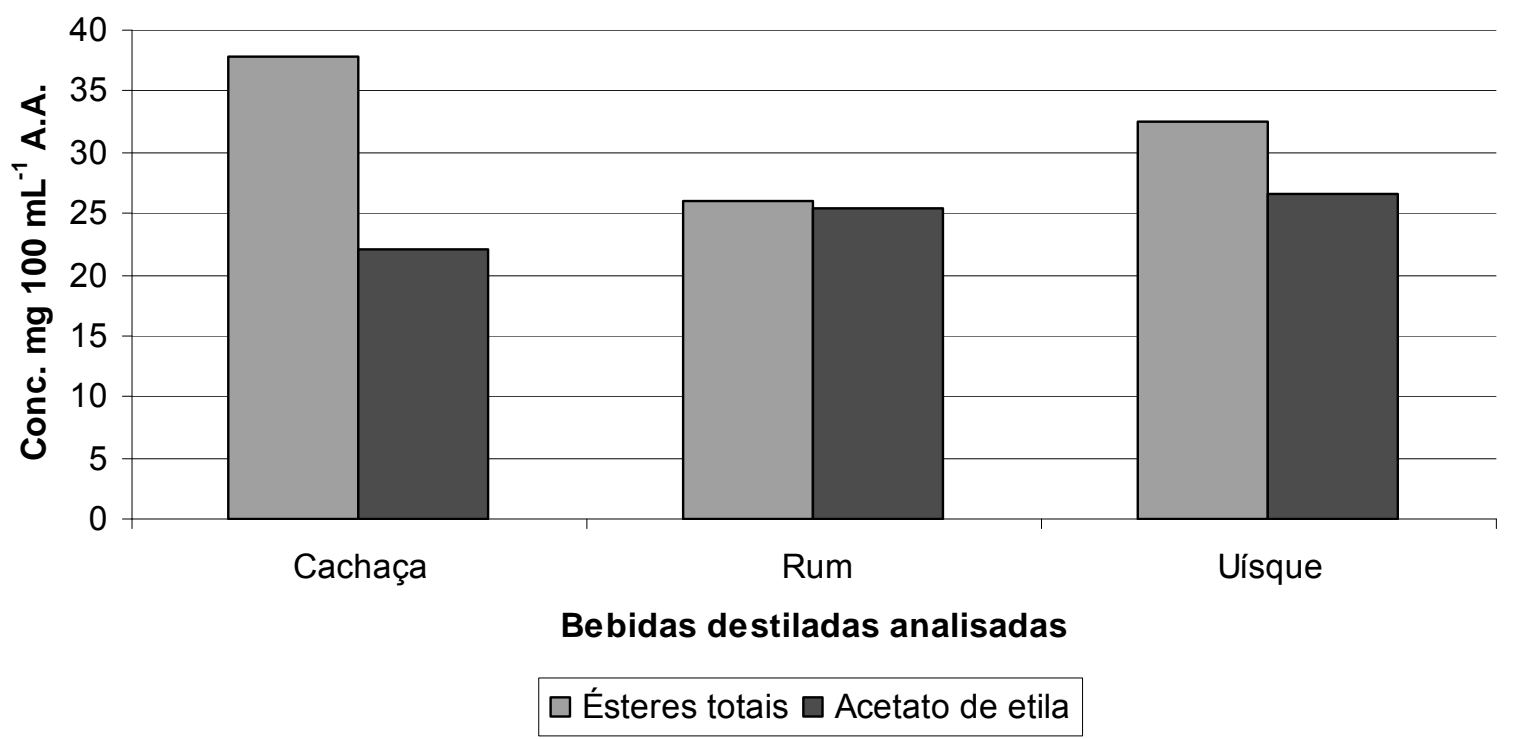

Figura 35. Concentração relativa de acetato de etila na concentração total de ésteres.

A concentração total de ésteres das amostras de cachaça e de uísque é ligeiramente superior à concentração total de ésteres nas amostras de rum. Pode-se observar na Figura 35, principalmente para a cachaça, que a concentração de acetato de etila não corresponde à concentração total de ésteres. De acordo com a legislação brasileira, que exige que a concentração total de ésteres seja expressa em termos de acetato de etila, os valores medidos para a concentração total de ésteres serão subestimados, conforme já mencionados neste trabalho, se não ocorrer a determinação de lactato de etila durante a análise cromatográfica. 
A Figura 36 compara a mediana da concentração de cada analito nas amostras de cachaça, rum e uísque.

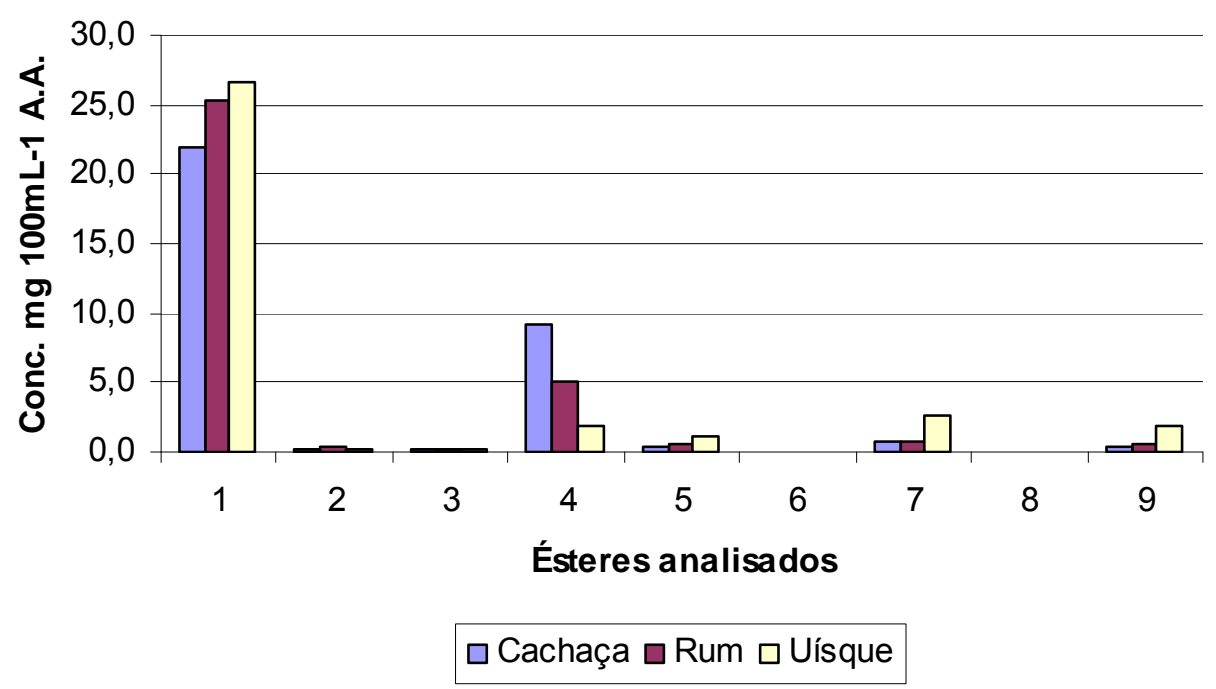

Figura 36. Histograma da mediana da concentração de cada analito nas amostras de cachaça, rum e uísque. 1 acetato de etila, 2 butanoato de etila, 3 hexanoato de etila, 4 lactato de etila, 5 octanoato de etila, 6 nonanoato de etila, 7 decanoato de etila, 8 octanoato de isoamila, 9 dodecanoato de etila.

Apesar de o lactato de etila estar presente tanto nas amostras de rum quanto nas amostras de uísque sua concentração é relativamente inferior quando comparado às amostras de cachaça. As concentrações de acetato de etila nas amostras de rum e uísque são superiores à concentração de acetato de etila nas amostras de cachaça. As amostras de uísque apresentaram um perfil químico de ésteres mais equilibrado, ou seja, com concentrações de ésteres próximas, quando comparado às amostras dos outros destilados.

Todas as amostras de uísque e algumas amostras de rum analisadas foram submetidas ao processo de envelhecimento e mesmo assim nenhuma amostra apresentou teores significativamente elevados de ésteres. Este dado corrobora com a proposta de que a formação dos ésteres etílicos está intrinsecamente relacionada 
com o metabolismo secundário das leveduras e não com o processo de envelhecimento. 


\section{CONSIDERAÇÕES FINAIS}

A metodologia analítica empregada para análise de ésteres demonstrou-se apropriada para a determinação destes compostos em bebidas destiladas, sendo simples (injeção direta), seletiva e relativamente rápida (36 minutos de corrida). Apresentou baixos limites de detecção $\left(0,0258\right.$ a $0,648 \mathrm{mg} 100 \mathrm{~mL}^{-1}$ de álcool anidro) e quantificação (0,0739 a 2,11 mg $100 \mathrm{~mL}^{-1}$ de álcool anidro) e boa repetibilidade (DPR 0,774 a 5,05\%) (Tabela 5).

A análise quantitativa mostrou que as amostras de aguardentes de cana destiladas em alambiques misto apresentaram uma concentração total de ésteres superior às amostras de aguardente de cana destiladas em alambiques de cobre e em colunas de aço inox (Figura 21).

A análise multivariada dos resultados analíticos das 136 amostras de aguardente de cana utilizando apenas as concentrações dos ésteres estudados neste trabalho não foi eficiente para separação das amostras que foram submetidas a diferentes processos de destilação. No entanto a combinação dos resultados obtidos para os ésteres com os obtidos para de carbamato de etila e benzaldeído permitem a distinção do conjunto em dois grupos bem definidos: amostras destiladas em alambiques de cobre e amostras destiladas em colunas de aço inox. Os modelos estatísticos gerados pelas análises exploratórias de PCA, PLS e LDA utilizando o carbamato de etila, benzaldeído, decanoato de etila e o dodecanoato de etila como discriminantes revelaram uma elevada probabilidade na diferenciação entre estes dois grupos com uma porcentagem de acerto de $81 \%$ para PCA, 78,4 \% para PLS e $97,6 \%$ para LDA. 
As análises quantitativas das amostras de cachaça, rum e uísque comercial revelaram que as amostras de aguardente de cana apresentam uma concentração de ésteres superior ao rum e ao uísque (Figura 25). A comparação da mediana da concentração de ésteres totais para a cachaça, rum e uísque mostrou que as que as bebidas que foram submetidas ao processo de envelhecimento não diferem significativamente em seus teores de ésteres totais quando comparadas às amostras não envelhecidas. Isto é devido ao fato de a formação dos ésteres etílicos estar relacionada ao processo de fermentação e não de envelhecimento.

O acetato de etila é o principal éster presente nas bebidas destiladas seguido pelo lactato de etila. Em todas as amostras de aguardente de cana analisadas neste trabalho foi detectada a presença do éster lactato etila. A presença deste éster está relacionada com a contaminação do mosto por bactérias (Lactobacillus spp) responsáveis pela fermentação láctica. A concentração de lactato de etila nas amostras de cachaça e rum é muito superior à encontrada nas amostras de uísque.

Ressalta-se que em nenhuma das metodologias cromatográficas sugeridas pelo MAPA o lactato de etila é monitorado e a metodologia volumétrica não é seletiva. 


\section{REFERÊNCIAS BIBLIOGRÁFICAS}

1. BRASIL. Ministério da Agricultura Pecuária e Abastecimento. Instrução Normativa n¹3, de 29 de junho de 2005. Diário Oficial da União, Brasília, 30 jun. 2005. Seção 1, p. 3-4.

2. CUBA. Ministério de la Industria Alimentícia. Resolucion $n^{\circ} 135 / 01$, de 13 março de 2001. Dispõe sobre o controle e qualidade de bebidas e licores. Cuba, 02 de maio 2002.

3. Regulamento de Avaliação da Conformidade (RAC). Portaria Inmetro $n^{\circ} 126$ de 24 de junho de 2005. Disponível em:

$<$ http://www.inmetro.gov.br/qualidade/produtosVoluntarios/cachaca.asp>. Acesso em: 23 fev. 2007.

4. Furlan e Rodrigues anunciam certificação da cachaça brasileira. Disponível em: <http://www.inmetro.gov.br/noticias/verNoticia.asp?seq_noticia=1580>. Acesso em: 23 fev. 2007.

5. Programa Brasileiro de Desenvolvimento da Cachaça (PBDAC). Disponível em: <http://www.cachacadobrasil.com.br>. Acesso em: 23 fev. 2007.

6. Instituto Brasileiro de Geografia e Estatística (IBGE). Disponível em: $<\mathrm{ftp}: / / \mathrm{ftp} . i b g$ e.gov.br/Estimativas_Projecoes_Populacao/Estimativas_2006/>. Acesso em: 23 fev. 2007.

7. VERARDO, E. CACHAÇA: um produto do agronegócio. São Paulo: Ferrari Editora e Artes Gráficas, 2006. Cap. 3, p. 25-26.

8. LEÃO, Daniella Arruda Falcão de Souza. Coopetição: Tipologia e Impactos no Desempenho das Empresas da Indústria de Cachaça de Alambique do Estado de Minas Gerais. 2004. 146 f. Dissertação (Mestrado em Administração) - Universidade Federal de Pernambuco, Recife, 2004.

9. NASCIMENTO, R. F.; CARDOSO, D. R.; KEUKELEIRE, D.; LIMA-NETO, B. S.; FRANCO, D. W. Quantitative HPLC Analysis of Acids in Brazilian Cachaças and Various Spirits Using Fluorescence Detection of Their 9-Anthrylmethyl Esters. Journal of Agricultural and Food Chemistry, v. 48, p. 6070-6073, 2000. 
10. NASCIMENTO, R. F.; CARDOSO, D. R.; LIMA-NETO, B. S.; FRANCO, D. W. Determination of acids in Brazilian sugar cane spirits and other alcoholic beverages by HRGC-SPE. Chromatographia, v. 48, p. 751-757, 1998.

11. BOSCOLO, M.; BEZERRA, C. W. B.; CARDOSO, D. R.; LIMA-NETO, B. S.; FRANCO, D. W. Identification and Dosage by HRGC of Minor alcohols and Esters in Brazilian Sugar-Cane Spirit. Journal of the Brazilian Chemical Society, v. 11, p. 86-90, 2000.

12. PEREZ, E. R.; CARDOSO, D. R.; FRANCO, D. W. Análise dos Álcoois, Ésteres e Compostos Carbonílicos em Amostras de Óleo Fúsel. Química Nova, v. 24, p. 10$12,2001$.

13. ANDRADE-SOBRINHO, L. G.; BOSCOLO, M.; LIMA-NETO, B. S.; FRANCO, D. W. Carbamato de Etila em Bebidas Alcoólicas (Cachaça, Tiquira, Uísque e Grapa). Química Nova, v. 25, p 1074-1077, 2002.

14. NASCIMENTO, R. F.; MARQUES, J. C.; LIMA-NETO, B. S.; KEUKELEIRE, D.; FRANCO, D. W. Qualitative and Quantitative High-Performance liquid chromatographic analysis of aldehydes in Brazilian Sugar Cane Spirits and other distilled alcoholic beverages. Journal of Chromatography A, v. 782, p. 13-23, 1997.

15. CARDOSO, D. R.; BETTIN, S. M.; RECHE, R. V.; LIMA-NETO, B. S.; FRANCO, D. W. HPLC-DAD analysis of ketones as their 2,4-dinitrophenylhydrazones in Brazilian sugar-cane spirits and rum. Journal of Food Composition and Analysis, v. 16, p. $563-573,2003$.

16. CARDOSO, D. R.; ANDRADE-SOBRINHO, L. G.; LIMA-NETO, B. S.; FRANCO, D. W. A Rapid and Sensitive Method for Dimethylsuphide Analysis in Brazilian Cane Sugar Spirits and other distilled beverages. Journal of the Brazilian Chemical Society, v. 15, p. 277-281, 2004.

17. NASCIMENTO, R. F.; BEZERRA, C. W. B.; FURUYA, S. M. B.; SCHULTZ, M. S.; POLASTRO, L. R.; LIMA-NETO, B. S.; FRANCO, D. W. Mineral Profile of Brazilian cachaças and other international spirits. Journal of Food Composition and Analysis, v. 12, p. 17-25, 1999.

18. BETTIN, S. M.; FRANCO, D. W.; ISIQUE, W. D.; KNUDSEN, S.; ANDERSEN, M. L.; SKIBSTED, L. H. Phenols and metals in sugar-cane spirits. Quantitative analysis and effect on radical formation and radical scavenging. European Food Research and Technology, v. 215, p. 169-175, 2002. 
19. BOSO, Lisangela Maria. Determinação de aminoácidos em flocos, açúcares e aguardente de cana. 2001. 110 f. Dissertação (Mestrado em Ciências (Química Analítica)) - Universidade de São Paulo, São Carlos, 2001.

20. GALINARO, C. A.; CARDOSO, D. R.; FRANCO, D. W. Profiles of polycyclic aromatic hydrocarbons in brazilian sugar cane spirits: discrimination between cachaças produced from non-burned and burned sugar cane crops. Journal of Agricultural and Food Chemistry. No prelo.

21. ISIQUE, W. D.; LIMA-NETO, B. S.; FRANCO, D. W. A Qualidade da Cachaça, Uma Opinião para Discussão. Engarrafador Moderno, v. 98, p. 33-36, 2002.

22. HART, H.; SCHUETZ, R. D. Química Orgânica. Rio de Janeiro: Campus, 1983. Cap. 11, p. 218-244.

23. LURTON, L.; SNAKKERS, G.; ROULLAND, C; GALY, B. Influence of the Fermentation Yeast-Strain on the Composition of Wine Spirits. Journal of Science and Food Agriculture. v. 67, p. 485-491, 1995.

24. SUOMALAINEN, H; LEHTONEN, M. Production of Aroma Compounds by Yeast. Journal of the Institute of Brewing. v. 85, p. 149-156, 1979.

25. CARAZZA, F.; CARDEAL, Z. L.; CARVALHO, C. R.; NONATO, E. A.; SILVA, F. C. A Headspace Solid-Phase Microextraction Method for the Determination of Some Secundary Compounds of Brazilian Sugar Cane Spirits by Chromatography. Journal of Agricultural and Food Chemistry. v. 49, p. 3533-3539, 2001.

26. NYKÄNEN, L; NYKÄNEN, I. Destilled Beverages. In: MAARSE, H. (Ed.). Volatile Compounds in Foods and Beverages. New York: Marcel Dekker, 1991. Cap. 15, p. 547-580.

27. PIGGOTT, J. R.; PATERSON, A. The contributions of the process to flavour in Scotch malt whisky. In: PIGGOTT, J. R.; PATERSON, A. (Eds.). Distilled beverage flavour: recent developments. New York: VCH, 1989. 352p.

28. BELITZ, H.-D.; GROSCH, W.; SCHIEBERLE, P. Food Chemistry. Berlin: Springer, 2004. Cap. 20, p. 892-938. 
29. ETIÉVANT, P. X. Wine. In: MAARSE, H. (Ed.). Volatile Compounds in Foods and Beverages. New York: Marcel Dekker, 1991. Cap. 14, p. 483-546.

30. DEMYTTENAERE, J. C. R.; KIMPE, N. D.; MARTÍNEZ, J. I. S.; SANDRA, P.; VERHÉ, R. Analysis of Volatiles of Malt Whisky by Solid-Phase Microextraction and Stir Bar Sorptive Extraction. Journal of Chrmatography A, v. 985, p. 221-232, 2003.

31. FITZGERALD, G.; JAMES, K. J.; MACNAMARA, K.; STACK, M. A. Characterisation of Whiskeys Using Solid-Phase Microextraction With Gas Chromatography - Mass Spectrometry. Journal of Chromatography A, v. 896, p. 351-359, 2000.

32. DAGHER, C.; DEMYTTENAERE, J. C. R.; KALLITHRAKA, S.; KIMPE, N. D.; SANDRA, P.; VERHÉ, R. Flavour Analysis of Greek White Wine by Solid-Phase Microextraction - Capillary Gas Chromatography - Mass Spectrometry. Journal of Chromatography A. v. 985, p. 233-246, 2003.

33. WEAST, R. C. CRC Handbook of chemistry and physics: A ready-reference book of chemical and physical data. Cleveland: CRC, p. 1977-1978.

34. CROW, V. L.; HOLLAND R.; LIU, S.-Q. Ester and Their Biosynthesis in Fermented Dairy Products: A Review. International Dairy Journal, v. 14, p. 923945, 2004.

35. FERREIRA, V; LÓPEZ, R.; HERNÁNDEZ, P; CACHO, J. F. Identification of impact odorants of young red wines made with Merlot, Cabernet Sauvignon and Grenache grape varieties: a comparative study. Journal of the Science of Food and Agriculture, v. 79, p. 1461-1467, 1999.

36. ROWE, D. More Fizz for Your Buck: High-impact Aroma Chemicals. Perfurmer \& Flavorist Magazine, v. 25, p. 1-19, 2000.

37. BELITZ, H.-D.; GROSCH, W.; SCHIEBERLE, P. In: Food Chemistry. Berlin: Springer, 2004. Cap. 5, p. 342-408.

38. ROSSITER, K. J. Structure - odor relationships. Chemical Reviews, v. 96, p. 3201-3240, 1996.

39. MCNAIR, H. M.; MILLER, J. M. Basic Gas Chromatography. New York: Wiley Interscience, 1997. Cap. 1, p. 1-13. 
40. LANÇAS, F. M. Cromatografia em Fase Gasosa. São Carlos: Acta, 1993. Cap. 3, p. 33-54.

41. HARRIS, D. C. Análise Química Quantitativa. Rio de Janeiro: LTC, 2005. Cap. 22 , p. 507-537.

42. LANÇAS, F. M. Cromatografia em Fase Gasosa. São Carlos: Acta, 1993. Cap. 4 , p. $55-88$.

43. SILVERSTEIN, R. M.; WEBSTER, F. X. Identificação Espectrométrica de Compostos Orgânicos. Rio de Janeiro: LTC, 2000. Cap. 2, p. 2-66.

44. SKOOG, D. A.; HOLLER, F. J.; NIEMAN, T. A. Princípios de Analise Instrumental. Porto Alegre: Bookman, 2002. Cap. 27, p. 620-641.

45. ETIÉVANT, P.; SCHLICH, P. Varietal and geographic classification of French red wines in terms of major acids. Journal of the Science of Food and Agriculture, v. 46, p. 421-438, 1989.

46. CARDOSO, D. R.; ANDRADE-SOBRINHO, L. G.; LEITE-NETO, A. F.; RECHE, R. V.; ISIQUE, W. D.; FERREIRA, M. M. C.; LIMA-NETO, B. S.; FRANCO, D. W. Comparison between cachaça and rum using pattern recognition methods. Journal of Agricultural and Food Chemistry, v. 52, p. 3429-3433, 2004.

47. MALKAVAARA, P. Chemometrics: An important tool for the modern chemist, an example from wood-processing chemistry. Journal of Chemical Information and Computer Science, v. 40, p. 438-441, 2000.

48. LAVINE, B.; WORKMAN, J. Chemometrics. Analytical Chemistry, v. 78, n. 12, p. 4137-4145, 2006.

49. BRUNS, R. E.; FAIGLE, J. F. G. Quimiometria. Química Nova, v. 8, n. 2, p. 8499, 1985.

50. LAVINE, B. K. Chemometrics. Analytical Chemistry, v. 72, n. 12, p. 91R-97R, 2000.

51. MILLER, J. N.; MILLER, J. C. Statistic and Chemometrics for AnalyticalChemistry. New York: Prentice Hall, 2000. Cap. 8, p. 214-238. 
52. HOPKE, P. K. The evolution of chemometrics. Analytica Chimica Acta, v. 500, p. 365-377, 2003.

53. RECHE, Roni Vicente. Aspectos da tipificação da aguardente. 2006. $154 \mathrm{f}$. Dissertação (Mestrado em Ciências (Química Analítica)) - Instituto de Química de São Carlos, Universidade de São Paulo, São Carlos, 2006.

54. RIBANI, M.; MELO, L. F. C.; BOTTOLI, C. B. G., COLLINS, C. H.; JARDIM, I. C. S. F. Validação em métodos cromatográficos e eletroforéticos. Química Nova, v. 27, p. 771-780, 2004.

55. HIGUCHI, T; SEKIGUSHI, O.; HOSHINO, M.; TAKAHASHI, Y.; TAJIMA, S. Unimolecular decomposition of ethyl lactate, $\mathrm{CH} 3 \mathrm{CH}(\mathrm{OH}) \mathrm{COOC} 2 \mathrm{H} 5$, upon electron impact. International Journal of Mass Spectrometry, v. 181, p. 89-98, 1998.

56. Metodologias sugeridas pelo Ministério da Agricultura, Pecuária e Abastecimento para a análise de destilados. Disponível em:

http://www.agricultura.gov.br/portal/page?_pageid=33,1040761\&_dad=portal\&_sche ma=PORTAL Acesso em: 14 de março de 2007.

57. GEDDES, P. A.; RIFFKIN, H. L. Influence of lactic acid bacteria on aldehyde, ester and higher alcohol formation during Scotch whisky fermentations. In:

PIGGOTT, J. A.; PATERSON, A. (Eds.). Distilled beverage flavour: recent developments. New York: VCH, 1989. Cap. 17, p. 193-199.

58. NASCIMENTO, R. F.; CARDOSO, D. R.; LIMA-NETO, B. S.; FARIA, J. B.; FRANCO, D. W. Influência do material do alambique na composição química das aguardentes de cana-de-açúcar. Química Nova, v. 21, p. 735-739, 1998.

59. ARESTA, M.; BOSCOLO, M.; FRANCO, D. W. Copper (II) catalysis in cyanide conversion into ethyl carbamate in spirits and relevant reactions. Journal of Agricultural and Food Chemistry. v. 49, n. 6, p. 2819-2824, 2001.

60. NICOL, D. Rum. In: PIGGOTT, J. R.; LEA, A. G. H. (Eds.). Fermented beverage production. New York: Kluwer Academic/Plenum Publishers, 2003. Cap. 12, p. 263287. 
ANEXO A - Concentração de álcool isoamílico, acetaldeído, carbamato de etila, benzaldeído e teor alcoólico das amostras de aguardente de cana analisadas.

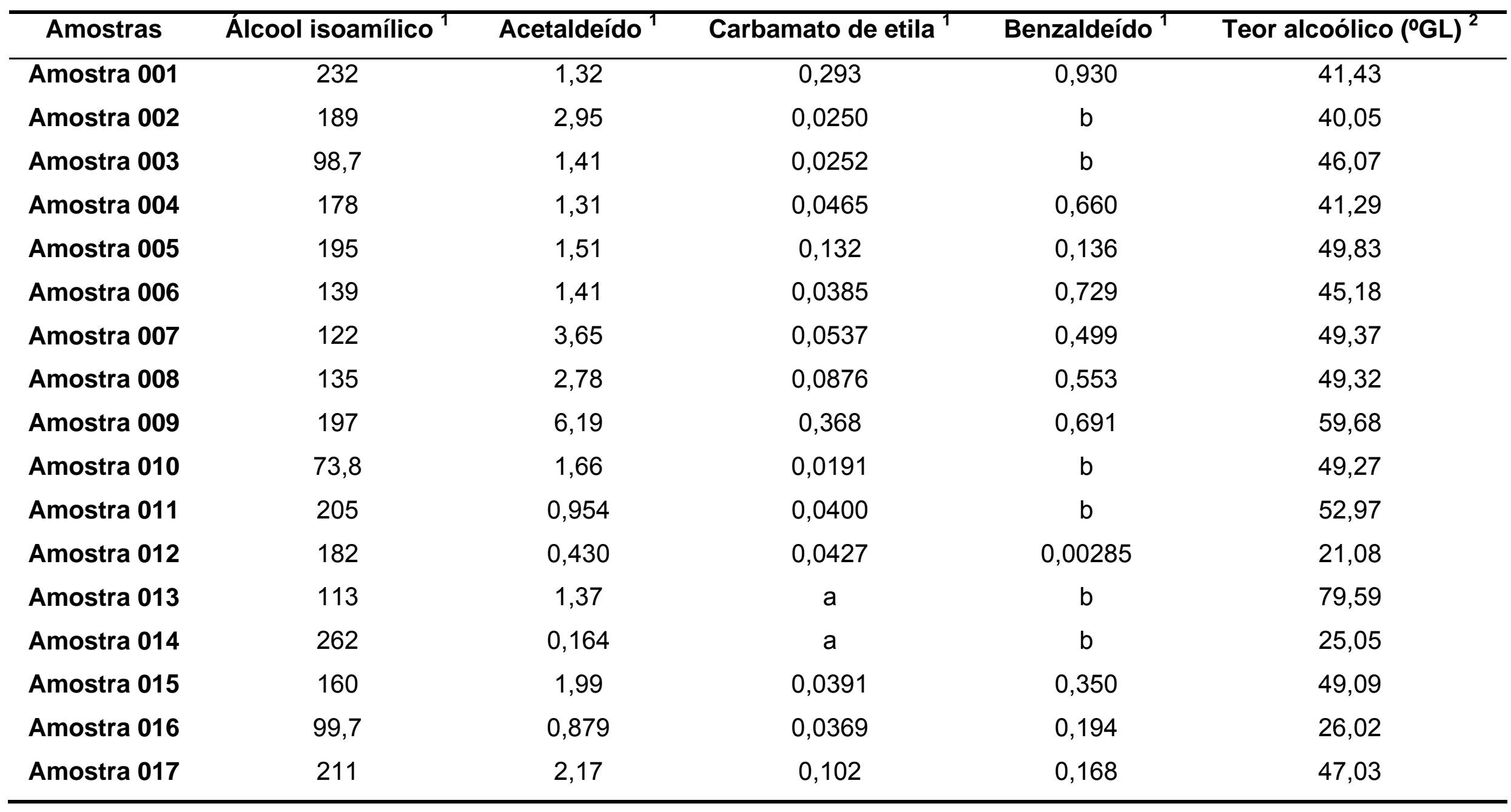


ANEXO A - Continuação.

\begin{tabular}{|c|c|c|c|c|c|}
\hline Amostras & Álcool isoamílico ${ }^{1}$ & Acetaldeído $^{1}$ & Carbamato de etila $^{1}$ & Benzaldeído $^{1}$ & Teor alcoólico $\left({ }^{\circ} \mathrm{GL}\right)^{2}$ \\
\hline Amostra 018 & 314 & 3,21 & 0,156 & 0,399 & 52,06 \\
\hline Amostra 019 & 309 & 12,4 & 0,0492 & 0,844 & 49,54 \\
\hline Amostra 021 & 25,1 & 0,355 & 0,0247 & 0,290 & 40,46 \\
\hline Amostra 022 & 253 & 3,43 & 0,105 & 0,289 & 74,31 \\
\hline Amostra 024 & 174 & 1,82 & 0,0261 & 0,0365 & 50,65 \\
\hline Amostra 025 & 123 & 7,02 & 0,0219 & b & 52,98 \\
\hline Amostra 026 & 138 & 1,77 & a & 0,0540 & 45,38 \\
\hline Amostra 027 & 22,9 & 0,456 & 0,0273 & $\mathrm{~b}$ & 40,28 \\
\hline Amostra 031 & 253 & 0,709 & 0,0511 & 0,390 & 45,4 \\
\hline Amostra 032 & 85,2 & 1,80 & 0,0457 & 0,0240 & 55,16 \\
\hline Amostra 033 & 238 & 4,09 & a & 0,00198 & 40,46 \\
\hline Amostra 034 & 122 & 0,535 & a & 0,0893 & 52,2 \\
\hline
\end{tabular}


ANEXO A - Continuação.

\begin{tabular}{|c|c|c|c|c|c|}
\hline Amostras & Álcool isoamílico ${ }^{1}$ & Acetaldeído $^{1}$ & Carbamato de etila $^{1}$ & Benzaldeído $^{1}$ & Teor alcoólico $\left({ }^{\circ} \mathrm{GL}\right)_{2}$ \\
\hline Amostra 035 & 147 & 0,561 & $a$ & $\mathrm{~b}$ & 38,2 \\
\hline Amostra 036 & 274 & 6,98 & 0,0205 & 0,102 & 58,55 \\
\hline Amostra 038 & 127 & 0,505 & a & $b$ & 46,77 \\
\hline Amostra 039 & 190 & 4,18 & a & b & 68,53 \\
\hline Amostra 041 & 90,5 & 3,38 & 0,0228 & b & 48,33 \\
\hline Amostra 042 & 37,7 & 0,859 & 0,0245 & b & 40,76 \\
\hline Amostra 043 & 13,6 & 0,471 & a & 0,00288 & 25,02 \\
\hline Amostra 044 & 51,4 & 0,909 & a & $\mathrm{b}$ & 49,94 \\
\hline Amostra 048 & 142 & 1,44 & a & $b$ & 50,04 \\
\hline Amostra 049 & 120 & 1,03 & a & $b$ & 44,56 \\
\hline Amostra 050 & 46,3 & 0,317 & a & $\mathrm{b}$ & 45,65 \\
\hline Amostra 051 & 25,5 & 0,472 & 0,323 & 0,00249 & 32,16 \\
\hline
\end{tabular}


ANEXO A - Continuação.

\begin{tabular}{|c|c|c|c|c|c|}
\hline Amostras & Álcool isoamílico ${ }^{1}$ & Acetaldeído $^{1}$ & Carbamato de etila $^{1}$ & Benzaldeído $^{1}$ & Teor alcoólico $\left({ }^{\circ} \mathrm{GL}\right)^{2}$ \\
\hline Amostra 052 & 84,3 & 2,78 & $a$ & $\mathrm{~b}$ & 38,52 \\
\hline Amostra 053 & 96,3 & 4,84 & a & b & 47,29 \\
\hline Amostra 055 & 140 & 1,89 & a & $b$ & 38,64 \\
\hline Amostra 056 & 119 & 6,78 & a & b & 52,3 \\
\hline Amostra 058 & 145 & 0,368 & 0,0965 & $\mathrm{~b}$ & 54,08 \\
\hline Amostra 059 & 124 & 0,933 & 0,0720 & 0,364 & 48,12 \\
\hline Amostra 060 & 91,7 & 0,230 & a & 0,963 & 38,52 \\
\hline Amostra 061 & 261 & 0,235 & a & $\mathrm{b}$ & 65,31 \\
\hline Amostra 065 & 379 & 2,53 & 0,0453 & $\mathrm{~b}$ & 51,18 \\
\hline Amostra 066 & 209 & 1,94 & 0,0329 & 0,766 & 54,64 \\
\hline Amostra 067 & 222 & 1,58 & 0,0299 & 0,00200 & 38,09 \\
\hline Amostra 068 & 42,9 & 0,820 & a & 0,0321 & 46,39 \\
\hline
\end{tabular}


ANEXO A - Continuação.

\begin{tabular}{|c|c|c|c|c|c|}
\hline Amostras & Álcool isoamílico ${ }^{1}$ & Acetaldeído $^{1}$ & Carbamato de etila $^{1}$ & Benzaldeído $^{1}$ & Teor alcoólico $\left({ }^{\circ} \mathrm{GL}\right)^{2}$ \\
\hline Amostra 069 & 211 & 3,17 & 0,0213 & $\mathrm{~b}$ & 52,59 \\
\hline Amostra 070 & 137 & 0,397 & 0,0234 & b & 44,45 \\
\hline Amostra 072 & 165 & 0,684 & a & 0,922 & 51,42 \\
\hline Amostra 073 & 156 & 2,63 & 0,0196 & 1,33 & 50,09 \\
\hline Amostra 075 & 201 & 2,35 & 0,0242 & 1,64 & 65,42 \\
\hline Amostra 076 & 228 & 5,85 & 0,0612 & 0,421 & 50,04 \\
\hline Amostra 077 & 175 & 1,27 & 0,0463 & 0,796 & 48,58 \\
\hline Amostra 078 & 241 & 2,32 & 0,0351 & 0,262 & 48,73 \\
\hline Amostra 082 & 168 & 1,55 & $a$ & $b$ & 56,65 \\
\hline Amostra 083 & 216 & 0,743 & a & 0,0108 & 48,68 \\
\hline Amostra 084 & 72,2 & 12,0 & a & 0,153 & 50,88 \\
\hline Amostra 085 & 346 & 2,21 & a & $b$ & 54,36 \\
\hline
\end{tabular}


ANEXO A - Continuação.

\begin{tabular}{|c|c|c|c|c|c|}
\hline Amostras & Álcool isoamílico ${ }^{1}$ & Acetaldeído $^{1}$ & Carbamato de etila $^{1}$ & Benzaldeído $^{1}$ & Teor alcoólico $\left({ }^{\circ} \mathrm{GL}\right)^{2}$ \\
\hline Amostra 086 & 71,5 & 1,18 & $a$ & $\mathrm{~b}$ & 72,53 \\
\hline Amostra 087 & 66,2 & 1,11 & 0,0334 & 0,147 & 40,4 \\
\hline Amostra 089 & 270 & 2,04 & a & 0,00468 & 42,78 \\
\hline Amostra 090 & 108 & 0,752 & a & b & 36,38 \\
\hline Amostra 092 & 28,1 & 0,151 & 0,0265 & $\mathrm{~b}$ & 42,26 \\
\hline Amostra 093 & 2,92 & 2,94 & a & 0,476 & 42,43 \\
\hline Amostra 094 & 136 & 0,829 & 0,102 & 0,780 & 49,49 \\
\hline Amostra 095 & 240 & 1,40 & 0,236 & 0,208 & 53,74 \\
\hline Amostra 099 & 171 & 1,68 & a & $b$ & 51,76 \\
\hline Amostra 100 & 121 & 7,07 & 0,0302 & $b$ & 56,55 \\
\hline Amostra 101 & 150 & 2,64 & a & 0,102 & 54,88 \\
\hline Amostra 102 & 225 & 11,4 & a & $b$ & 53,7 \\
\hline
\end{tabular}


ANEXO A - Continuação.

\begin{tabular}{|c|c|c|c|c|c|}
\hline Amostras & Álcool isoamílico ${ }^{1}$ & Acetaldeído $^{1}$ & Carbamato de etila $^{1}$ & Benzaldeído $^{1}$ & Teor alcoólico $\left({ }^{\circ} \mathrm{GL}\right)^{2}$ \\
\hline Amostra 103 & 441 & 8,44 & 0,0523 & $\mathrm{~b}$ & 53,55 \\
\hline Amostra 104 & 130 & 1,86 & a & b & 46,61 \\
\hline Amostra 105 & 52,6 & 1,26 & a & $\mathrm{b}$ & 39,87 \\
\hline Amostra 106 & 170 & 8,28 & 0,0315 & 0,896 & 49,54 \\
\hline Amostra 107 & 75,5 & 1,01 & 0,0227 & b & 44,13 \\
\hline Amostra 108 & - & - & - & - & 53,08 \\
\hline Amostra 109 & - & - & - & - & 49,24 \\
\hline Amostra 110 & - & - & - & - & 39,62 \\
\hline Amostra 111 & - & - & - & - & 38,09 \\
\hline Amostra 112 & - & - & - & - & 46,55 \\
\hline Amostra 113 & - & - & - & - & 52,64 \\
\hline Amostra 114 & - & - & - & - & 53,17 \\
\hline Amostra 115 & - & - & - & - & 49,54 \\
\hline Amostra 116 & - & - & - & - & 50,44 \\
\hline Amostra 117 & - & - & - & - & 45,71 \\
\hline Amostra 118 & - & - & - & - & 50,04 \\
\hline Amostra 119 & - & - & - & - & 49,14 \\
\hline
\end{tabular}


ANEXO A - Continuação.

\begin{tabular}{cccccc}
\hline Amostras & Álcool isoamílico $^{1}$ & Acetaldeído $^{1}$ & Carbamato de etila $^{1}$ & Benzaldeído $^{1}$ & ${\left.\text { Teor alcoólico ( }{ }^{\circ} \mathrm{GL}\right)^{2}}^{{ }^{2}}$ \\
\hline Amostra 120 & - & - & - & - & 43,06 \\
Amostra 121 & - & - & - & - & 43,34 \\
Amostra 122 & - & - & - & - & 44,78 \\
Amostra 123 & - & - & - & - & 37,21 \\
Amostra 124 & - & - & - & - & 53,41 \\
Amostra 125 & - & - & - & - & 51,32 \\
Amostra 126 & - & - & - & - & 53,79 \\
Amostra 127 & - & - & - & - & 48,99 \\
Amostra 128 & - & - & - & - & 45,27 \\
Amostra 129 & - & - & - & - & 51,67 \\
Amostra 130 & - & - & - & - & 68,28 \\
Amostra 131 & - & - & - & - & 46,55 \\
Amostra 132 & - & - & - & - & 38,7 \\
Amostra 133 & - & - & - & - & 43,74 \\
Amostra 134 & - & - & - & - & 36,9 \\
Amostra 135 & - & - & - & - & 32,8 \\
Amostra 136 & - & - & - & 44,56 \\
\hline
\end{tabular}


ANEXO A - Continuação.

1 = Concentração em mg $100 \mathrm{~mL}^{-1}$ de álcool anidro.

2 = Teor alcoólico em graus GL (grau Gay-Lussac \% v/v álcool etílico).

$\mathrm{a}=$ valor menor $0,0100 \mathrm{mg} 100 \mathrm{~mL}^{-1}$ álcool anidro.

$\mathrm{b}=$ valor menor que $0,002 \mathrm{mg} 100 \mathrm{~mL}^{-1}$ álcool anidro.

Obs: Os teores de álcool isoamílico, acetaldeído, carbamato de etila e benzaldeído das amostras 108 a 136 não foram medidos. 0 teor alcoólico de todas as amostras foi determinado pelo método do picnômetro. 
ANEXO B - Metodologia sugerida pelo Ministério da Agricultura, Pecuária e Abastecimento para a determinação de ésteres (ésteres etílicos - volumetria). Ministério da Agricultura, Pecuária e Abastecimento - MAPA Secretaria de Defesa Agropecuária - SDA Coordenação Geral de Apoio Laboratorial - CGAL

Manual de Métodos de Análises de Bebidas e Vinagres

Destilados ESTERES TOTAIS Método 13

\section{MÉTODO}

Químico.

\section{PRINCÍPIO}

Os ésteres são hidrolisados com hidróxido de sódio e o excesso de álcali é determinado por titulação.

\section{MATERIAL}

\subsection{Equipamento}

a) Condensador de refluxo (Graham com $60 \mathrm{~cm}$ de altura, ou compatível).

b) Banho-maria. 


\subsection{Reagente}

a) Solução de hidróxido de sódio 0,1 N.

b) Solução de ácido sulfúrico $0,1 \mathrm{~N}$.

c) Solução de fenolftaleína a $1 \%(\mathrm{~m} / \mathrm{V})$ em álcool 95\% em volume.

\subsection{Vidraria}

a) Erlenmeyer de $500 \mathrm{~mL}$ com boca esmerilhada.

b) Pipeta volumétrica de $100 \mathrm{~mL}$.

c) Buretas de $10 \mathrm{~mL}$.

\section{PROCEDIMENTO}

Pipetar $100 \mathrm{~mL}$ do destilado da amostra (usado para determinação do grau alcoólico real) para um Erlenmeyer de $500 \mathrm{~mL}$ e neutralizar com solução de hidróxido de sódio, usando como indicador a fenolftaleína. Adicionar exatamente $10 \mathrm{~mL}$ de solução de hidróxido de sódio $0,1 \mathrm{~N}$ e deixar em refluxo durante uma hora em banho-maria ou em repouso em frasco de vedação por doze horas. No caso da cor rosa desaparecer, resfriar e adicionar mais $10 \mathrm{~mL}$ da solução de hidróxido de sódio e deixar em refluxo por mais meia hora. Resfriar rapidamente e adicionar solução de ácido sulfúrico $0,1 \mathrm{~N}$ (10 ou $20 \mathrm{~mL}$ conforme se tenha adicionado 10 ou $20 \mathrm{~mL}$ de solução de hidróxido de sódio). Titular o excesso de ácido sulfúrico com solução de hidróxido de sódio $0,1 \mathrm{~N}$ até coloração rósea. 


\section{CÁLCULO E EXPRESSÃO DOS RESULTADOS}

A concentração de ésteres é expressa em miligramas de acetato de etila por $100 \mathrm{~mL}$ de álcool anidro:

$$
E_{a a}=\frac{n \times N \times 8,8 \times 100}{V \times G R} \times 1000
$$

Onde:

$E_{a a}=$ Concentração de ésteres em mg/ $100 \mathrm{~mL}$ de álcool anidro.

$G R=$ Grau alcoólico real .

$n$ = Volume em $\mathrm{mL}$ da solução de hidróxido de sódio gasto na titulação.

$N$ = Normalidade da solução de hidróxido de sódio.

$V=$ Volume em $\mathrm{mL}$ da amostra titulada

\section{REFERÊNCIA}

BRASIL. Ministério da Agricultura. Portaria n 76 de 26 de novembro de 1986. Dispõe sobre os métodos analíticos de bebidas e vinagre. Diário Oficial da República Federativa do Brasil, Brasília, 28 nov. 1986. Seção 1, pt. 2.

Recueil des méthodes internationales d'analyse des boissons spiritueuses, des alcools et de la fraction aromatique des boisssons., OIV, Juin. 1994, Paris, 311p. 
ANEXO C - Metodologia sugerida pelo Ministério da Agricultura, Pecuária e Abastecimento para a determinação de ésteres (acetato de etila - cromatografia gasosa).

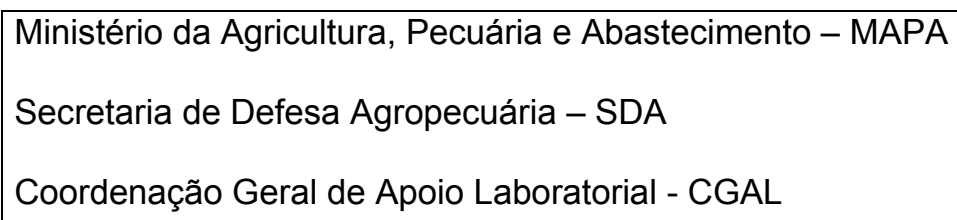

\section{MÉTODO}

Cromatográfico.

\section{PRINCÍPIO}

Adiciona-se uma mesma quantidade do padrão interno (metil-4 pentanol-2) a bebida destilada e a uma solução com as substâncias que serão dosadas (concentração conhecida). As duas soluções são injetadas diretamente no cromatógrafo e os picos correspondentes são comparados. Para efeito de cálculos das concentrações, a diferença do pico do padrão interno nas duas soluções é levada em consideração. 


\section{MATERIAL}

\subsection{Equipamento}

a) Cromatógrafo de fase gasosa equipado com detector de ionização de chama (FID).

b) Coluna que permita separação das substâncias que se deseja determinar. Como exemplo: coluna capilar de sílica fundida do tipo CPWAX $57 \mathrm{CB}, 50 \mathrm{~m}$ x 0,22 mm e espessura da fase fixa de 0,2 $\mu \mathrm{m}$ (Marca Chrompack).

Condições operatórias dadas a título de exemplo:

Sistema de injeção:

Split: razão 1/60

Volume injetado $0,5 \mu \mathrm{L}$

Condições cromatográficas:

Temperatura de injeção $220^{\circ} \mathrm{C}$

Temperatura do detector $220^{\circ} \mathrm{C}$

Programa de temperatura do forno:

Isoterma $40{ }^{\circ} \mathrm{C}$ durante 5 minutos

Aumento de $4{ }^{\circ} \mathrm{C} / \mathrm{min}$. até $200^{\circ} \mathrm{C}$.

c) Balança de precisão $(0,1 \mathrm{mg})$.

d) Trompa de água para limpar as seringas. 


\subsection{Reagentes e soluções}

a) Etanol puro, isento de traços das substâncias que serão dosadas (usado para mistura hidroalcoólica a $50 \%$ ).

b) Solução de padrão interno. Solução de metil-4 pentanol-2, a 50 gramas por litro da mistura hidroalcoólica a $50 \%$.

c) Solução de referência. Solução contendo, por litro da mistura hidroalcoólica a $50 \%$.

$125 \mathrm{mg}$ de butanol-2.

$125 \mathrm{mg}$ de propanol-1.

500 mg de metil-2 propanol-1.

50 mg de álcool alílico.

$50 \mathrm{mg}$ de butanol-1.

$1000 \mathrm{mg}$ de uma mistura (25:75, V/V) de metil-2 butanol-1 e metil-3 butanol-1, respectivamente.

\subsection{Vidraria}

a) Microsseringas de 5 a $10 \mu \mathrm{L}$ ou injetor automático.

b) Microsseringa de $100 \mu \mathrm{L}$ para adição do padrão interno.

c) Vidraria de laboratório. 


\section{PROCEDIMENTO}

\subsection{Preparação da amostra}

Juntar $50 \mu \mathrm{L}$ da solução de padrão interno a $5 \mathrm{~mL}$ da bebida espirituosa ou seu destilado (se a diferença entre os títulos alcoolimétricos bruto e real é inferior a $0,5 \%$, a bebida esperituosa bruta pode ser utilizada no lugar do destilado).

\subsection{Preparação da solução de referência}

Juntar $50 \mu \mathrm{L}$ da solução de padrão interno a $5 \mathrm{~mL}$ da solução de referência (3.2.c)

\subsection{Cromatografia}

Injetar no aparelho $0,5 \mu \mathrm{L}$ da amostra e $0,5 \mu \mathrm{L}$ da solução de referência se o aparelho estiver equipado com coluna capilar. Do contrário faça injeção de 1,0 $\mu \mathrm{L}$.

\section{CÁlCULOS E RESULTADOS}

De acordo com a área dos picos (eventualmente de acordo com as alturas), calcular a concentração de cada um dos álcoois em miligramas por $100 \mathrm{~mL}$ da bebida espirituosa.

A soma das concentrações dos álcoois encontrados fornece a quantidade dos álcoois superiores. 


\section{REFERÊNCIA}

Recueil des méthodes internationales d'analyse des boissons spiritueuses, des alcools et de la fraction aromatique des boisssons., OIV, Juin. 1994, Paris, 311p. 
ANEXO D - Metodologia sugerida pelo Ministério da Agricultura, Pecuária e Abastecimento para a determinação de ésteres (ésteres etílicos - cromatografia gasosa).

\begin{tabular}{|c|c|c|}
\hline $\begin{array}{l}\text { Ministério da Agricu } \\
\text { Secretaria de Defes } \\
\text { Coordenação Geral }\end{array}$ & $\begin{array}{l}\text { ecuária e Abastecimento - MAPA } \\
\text { ecuária - SDA } \\
\text { io Laboratorial - CGAL }\end{array}$ & \\
\hline \multicolumn{3}{|c|}{ Manual de Métodos de Análises de Bebidas e Vinagres } \\
\hline Destilados & $\begin{array}{l}\text { ÉSTERES ETÍLICOS, DERIVADOS } \\
\text { DE ÁC. GRAXOS, HEXANOL, FENIL- } \\
\text { 2-ETANOL E ÁC. VOLÁTEIS }\end{array}$ & Método 25 \\
\hline
\end{tabular}

\section{MÉTODO}

Cromatográfico.

\section{PRINCÍPIO}

Separação cromatográfica e identificação.

\section{MATERIAL}

\subsection{Equipamento}

a) Cromatógrafo em fase gasosa equipado com detector de ionização de chama.

b) Coluna capilar de sílica fundida, a título de exemplo, do tipo Carbowax $20 \mathrm{M}$ ou FFAP $50 \mathrm{~m} \times 0,22 \mathrm{~mm}$ de espessura de $0,2 \mu \mathrm{M}$. 
Nota: As seguintes condições de operação são dados a título de exemplo: sistema de injeção split (1/30); volume injetado de $1 \mu \mathrm{L}$; injetor e detector ambos a $220{ }^{\circ} \mathrm{C}$. Programa do forno: temperatura inicial de $40{ }^{\circ} \mathrm{C}$ aumentando a $3{ }^{\circ} \mathrm{C} /$ minuto até $200{ }^{\circ} \mathrm{C}$ mantendo isoterma a esta temperatura durante 15 minutos.

c) Balança de precisão.

d) Trompa de água para limpeza das seringas.

e) Agitador magnético.

\subsection{Soluções e reagentes}

\subsubsection{Reagentes}
a) Etanol puro (padrão cromatográfico).
b) Éter puro (padrão cromatográfico).
c) Hexano puro (padrão cromatográfico).

\subsubsection{Padrões internos}
a) Solução de octanol-3 (1 g/L em etanol $80 \%$ (V/V)).
b) Ácido heptanóico (1 g/L em etanol $80 \%$ (V/V)).

Nota: Os dois padrões podem ser colocados na mesma solução. 


\subsubsection{Soluções de referência}

A massa descrita abaixo esta contida em 1 litro de solução de etanol $50 \%$ (V/N).

a) $10 \mathrm{mg}$ de hexanol.

b) $10 \mathrm{mg}$ de fenil-2-etanol.

c) $5 \mathrm{mg}$ de acetato de metil-3-butila.

d) $1 \mathrm{mg}$ de acetato de hexila.

e) $5 \mathrm{mg}$ de acetato de fenil-2-etila.

f) $5 \mathrm{mg}$ de butanoato de etila.

g) $5 \mathrm{mg}$ de hexanoato de etila.

h) $20 \mathrm{mg}$ de octanoato de etila.

i) $20 \mathrm{mg}$ de decanoato de etila.

j) $10 \mathrm{mg}$ de dodecanoato de etila.

k) $5 \mathrm{mg}$ de tetradecanoato de etila.

I) $5 \mathrm{mg}$ de hexadecanoato de etila.

m) $5 \mathrm{mg}$ de succinato de dietila.

n) 5 mg de ácido metil-2-propanóico.

o) $5 \mathrm{mg}$ de ácido butanóico.

p) $5 \mathrm{mg}$ de ácido metil-3-butanóico.

q) $5 \mathrm{mg}$ de ácido hexanóico.

r) 20 mg de ácido octanóico.

s) 20 mg de ácido decanóico.

t) $10 \mathrm{mg}$ de ácido dodecanóico. 


\subsection{Vidraria e outros materiais}

a) Microseringa de $10 \mu \mathrm{L}$ ou injetor automático.

b) Microseringa de $100 \mu \mathrm{L}$ para injeção do padrão.

c) Funil de decantação de $100 \mathrm{~mL}$.

d) Pipetas volumétricas adequadas.

e) Balões volumétricos adequados.

\section{PROCEDIMENTO}

\subsection{Extração}

Tome $10 \mathrm{~mL}$ do destilado e adicione $100 \mu \mathrm{L}$ de cada padrão interno (ou $100 \mu \mathrm{L}$ da solução com os dois padrões). Diluir para $50 \mathrm{~mL}$ com água ultrapura. Adicionar $100 \mu \mathrm{L}$ de ácido sulfúrico e $4 \mathrm{~mL}$ de uma mistura recém preparada de éter:hexano (1:1 V/V). Agitar cinco minutos de tal forma que o cone formado na solução desça até a barra de agitação. Transferir para o funil de decantação e decantar. Recolher a fase superior (orgânica). Decantar mais duas vezes a fase aquosa agora com $2 \mathrm{~mL}$ da mistura de éter:hexano. Juntar as três porções orgânicas e misturá-las com auxílio de uma lenta agitação magnética. Decantar extraindo a fase aquosa (inferior) com a ajuda de uma seringa. 


\subsection{Determinação}

Injetar $1 \mu \mathrm{L}$ do extrato obtido em 4.1 no modo "splitless" no cromatógrafo. Da mesma forma se faz a injeção da solução de referência. A solução de referência deve conter todas as substâncias que serão determinadas em concentrações conhecidas, após a diluição. O grau alcoólico da solução de referência deve ser próximo ao do destilado em análise.

\section{CÁLCULOS E EXPRESSÃO DO RESULTADO}

De acordo com a área dos picos (ou altura) calcula-se a concentração de cada uma das substâncias em miligramas por litro de destilado (mg/100 mL de álcool anidro).

$$
C=\frac{C p \times A a \times F}{G R \times A p} \times 10
$$

$C$ = Concentração da substância em mg/100 mL de a.a..

$C p$ = Concentração da substância na solução de referência em mg/L.

$A a=$ Área (ou altura) do pico da amostra.

$A p=$ Área (ou altura) do pico da substância de referência.

$F$ = Fator de diluição (Volume antes da extração/ volume inicial da amostra).

GR = Grau alcoólico real em \%vol.

\section{REFERÊNCIA}

Recueil des méthodes internationales d'analyse des boissons spiritueuses, des alcools et de la fraction aromatique des boisssons., OIV, Juin. 1994, Paris, 311p. 
ANEXO E - Modelo do questionário entregue aos produtores de aguardente de cana no período de coleta das amostras.

\section{Questionário de identificação e tipificação}

Data:

Nome do Produtor:

Nome do Produto:

Local:

Altitude:

Município:

Telefone:

Celular:

Endereço para contato:

e-mail:

Fax:

Produção Anual:

Espécie de Cana:

Origem da Cana: Própria ( ) Comprada ( )

Colheita: Crua ( ) Queimada ( ) Tipo de Solo:

Cana lavada: Sim ( ) Não ( )

Uso de defensivos: Sim ( ) Não ( )

Tipo de Alambique: Cobre ( ) Inox ( ) Alumínio ( ) Outro ( )

Tipo de Coluna:

Possui dispositivo de cobre: Sim ( ) Não ( )

Origem da Água de Corte: Poço ( ) Estação de tratamento ( ) Outros ( )

Existe outro tratamento da água antes do corte: Sim ( ) Não ( )

Qual o tipo de fermento usado na fermentação:

A dorna de fermentação é feita de qual material ?

Adiciona alguma substância durante a fermentação ? Qual ?

Produto Orgânico ? Sim ( ) Não ( )

Destilação: Simples ( ) Bidestilada ( )

Separa cabeça e cauda?

Observar a posição do poço artesiano, se houver:

Observações gerais: 
ANEXO F - Tipo do destilador das amostras de aguardente de cana.

\begin{tabular}{|c|c|}
\hline Código da amostra & Tipo do destilador \\
\hline 001 & Coluna de aço inoxidável \\
\hline 002 & Alambique de cobre \\
\hline 003 & Alambique de cobre \\
\hline 004 & Coluna de aço inoxidável \\
\hline 005 & Coluna de aço inoxidável \\
\hline 006 & Coluna de aço inoxidável \\
\hline 007 & Coluna de aço inoxidável \\
\hline 008 & Coluna de aço inoxidável \\
\hline 009 & Coluna de aço inoxidável \\
\hline 010 & Alambique misto \\
\hline 011 & Alambique de cobre \\
\hline 012 & Alambique de cobre \\
\hline 013 & Alambique de cobre \\
\hline 014 & Alambique de cobre \\
\hline 015 & Coluna de aço inoxidável \\
\hline 016 & Alambique de cobre \\
\hline 017 & Coluna de aço inoxidável \\
\hline 018 & Coluna de aço inoxidável \\
\hline 019 & Coluna de aço inoxidável \\
\hline 020 & Coluna de aço inoxidável \\
\hline 021 & Alambique misto \\
\hline 022 & Coluna de aço inoxidável \\
\hline 023 & Alambique de cobre \\
\hline 024 & Alambique misto \\
\hline 025 & Alambique de cobre \\
\hline 026 & Alambique de cobre \\
\hline 027 & Alambique de cobre \\
\hline 028 & Alambique de cobre \\
\hline 029 & Alambique misto \\
\hline 030 & Alambique de cobre \\
\hline
\end{tabular}


ANEXO F - Continuação.

\begin{tabular}{|c|c|}
\hline Código da amostra & Tipo do destilador \\
\hline 031 & Alambique misto \\
\hline 032 & Alambique misto \\
\hline 033 & Alambique de cobre \\
\hline 034 & Alambique de cobre \\
\hline 035 & Alambique de cobre \\
\hline 036 & Alambique misto \\
\hline 037 & Alambique de cobre \\
\hline 038 & Alambique de cobre \\
\hline 039 & Alambique de cobre \\
\hline 040 & Alambique de cobre \\
\hline 041 & Alambique de cobre \\
\hline 042 & Alambique de cobre \\
\hline 043 & Alambique de cobre \\
\hline 044 & Alambique de cobre \\
\hline 045 & Alambique de cobre \\
\hline 046 & Alambique de cobre \\
\hline 047 & Alambique de cobre \\
\hline 048 & Alambique de cobre \\
\hline 049 & Alambique de cobre \\
\hline 050 & Alambique de cobre \\
\hline 051 & Alambique de cobre \\
\hline 052 & Alambique de cobre \\
\hline 053 & Alambique de cobre \\
\hline 054 & Alambique misto \\
\hline 055 & Alambique misto \\
\hline 056 & Alambique misto \\
\hline 057 & Coluna de aço inoxidável \\
\hline 058 & Alambique misto \\
\hline 059 & Coluna de aço inoxidável \\
\hline 060 & Coluna de aço inoxidável \\
\hline
\end{tabular}


ANEXO F - Continuação.

\begin{tabular}{|c|c|}
\hline Código da amostra & Tipo do destilador \\
\hline 061 & Alambique misto \\
\hline 062 & Alambique misto \\
\hline 063 & Alambique de cobre \\
\hline 064 & Alambique misto \\
\hline 065 & Alambique de cobre \\
\hline 066 & Coluna de aço inoxidável \\
\hline 067 & Alambique de cobre \\
\hline 068 & Alambique de cobre \\
\hline 069 & Alambique de cobre \\
\hline 070 & Alambique de cobre \\
\hline 071 & Alambique de cobre \\
\hline 072 & Coluna de aço inoxidável \\
\hline 073 & Coluna de aço inoxidável \\
\hline 074 & Coluna de aço inoxidável \\
\hline 075 & Coluna de aço inoxidável \\
\hline 076 & Coluna de aço inoxidável \\
\hline 077 & Coluna de aço inoxidável \\
\hline 078 & Alambique misto \\
\hline 079 & Alambique de cobre \\
\hline 080 & Alambique de cobre \\
\hline 081 & Alambique de cobre \\
\hline 082 & Alambique de cobre \\
\hline 083 & Alambique misto \\
\hline 084 & Alambique misto \\
\hline 085 & Alambique de cobre \\
\hline 086 & Alambique de cobre \\
\hline 087 & Alambique misto \\
\hline 088 & Alambique misto \\
\hline 089 & Alambique misto \\
\hline 090 & Alambique de cobre \\
\hline
\end{tabular}


ANEXO F - Continuação.

\begin{tabular}{|c|c|}
\hline Código da amostra & Tipo do destilador \\
\hline 091 & Alambique misto \\
\hline 092 & Alambique misto \\
\hline 093 & Coluna de aço inoxidável \\
\hline 094 & Coluna de aço inoxidável \\
\hline 095 & Coluna de aço inoxidável \\
\hline 096 & Alambique de cobre \\
\hline 097 & Alambique de cobre \\
\hline 098 & Alambique misto \\
\hline 099 & Alambique de cobre \\
\hline 100 & Alambique de cobre \\
\hline 101 & Alambique de cobre \\
\hline 102 & Alambique misto \\
\hline 103 & Alambique misto \\
\hline 104 & Alambique de cobre \\
\hline 105 & Alambique de cobre \\
\hline 106 & Coluna de aço inoxidável \\
\hline 107 & Alambique de cobre \\
\hline 108 & Alambique de cobre \\
\hline 109 & Alambique misto \\
\hline 110 & Alambique misto \\
\hline 111 & Alambique misto \\
\hline 112 & Alambique misto \\
\hline 113 & Alambique de cobre \\
\hline 114 & Alambique misto \\
\hline 115 & Alambique de cobre \\
\hline 116 & Alambique de cobre \\
\hline 117 & Alambique misto \\
\hline 118 & Alambique misto \\
\hline 119 & Alambique misto \\
\hline 120 & Alambique de cobre \\
\hline
\end{tabular}


ANEXO F - Continuação.

\begin{tabular}{cc}
\hline Código da amostra & Tipo do destilador \\
\hline 121 & Alambique misto \\
122 & Alambique misto \\
123 & Alambique de cobre \\
124 & Alambique misto \\
125 & Alambique misto \\
126 & Alambique misto \\
127 & Alambique de cobre \\
128 & Alambique de cobre \\
129 & Alambique de cobre \\
130 & Alambique de cobre \\
131 & Alambique misto \\
132 & Alambique de cobre \\
133 & Alambique de cobre \\
134 & Alambique de cobre \\
135 & Alambique de cobre \\
136 & Alambique misto \\
\hline
\end{tabular}


ANEXO G - Cachaças comerciais analisadas e cidades onde foram produzidas.

\begin{tabular}{|c|c|}
\hline Nome do Produto & Cidade - Estado \\
\hline Cachaça Volúpia b $^{\text {b }}$ & Alagoa Grande - PB \\
\hline Cachaça Campanari $^{d}$ & Monte Alegre do Sul - SP \\
\hline Chora Menina $^{\mathrm{e}}$ & Monte Alegre do Sul - SP \\
\hline Cachaça São Saruê ${ }^{\text {b }}$ & Igarassu - PE \\
\hline Cachaça Reserva do Gerente $^{d}$ & Avaré - SP \\
\hline Cachaça Porão e & Itapira - SP \\
\hline Cachaça Caribeña ${ }^{\text {b }}$ & Estância do Socorro - SP \\
\hline Cachaça Caribeña $^{e}$ & Estância do Socorro - SP \\
\hline Cachaça Senior ${ }^{e}$ & Caldas Novas - GO \\
\hline Elisa Airosa Prata ${ }^{d}$ & Patrocínio Paulista - SP \\
\hline Elisa Airosa Prata ${ }^{\text {e }}$ & Patrocínio Paulista - SP \\
\hline Aguardente Tiquara $^{\mathrm{e}}$ & Arealva - SP \\
\hline Cachaça Aroma Brasil ${ }^{\text {d } 1}$ & Monte Alegre de Minas - MG \\
\hline Cachaça Aroma Brasil d 2 & Monte Alegre de Minas - MG \\
\hline Cachaça Engenho da Vertente Premium ${ }^{\mathrm{e}}$ & Santo Antônio do Jardim - SP \\
\hline Reserva do Tanoeiro Gold ${ }^{\mathrm{e}}$ & Avaré - SP \\
\hline Armazém Vieira Terra ${ }^{\mathrm{e}}$ & Florianópolis - SC \\
\hline Armazém Vieira Safira ${ }^{e}$ & Florianópolis - SC \\
\hline Souza Andrade e Fonseca ${ }^{e}$ & Mindurí - MG \\
\hline Cachaça Valle ${ }^{\mathrm{e}}$ & Cruzília - MG \\
\hline Valle - S. Andrade e Fonseca ${ }^{\text {e }}$ & Cruzília-Mindurí - MG \\
\hline \multicolumn{2}{|l|}{$\mathrm{b}=$ branca } \\
\hline \multicolumn{2}{|l|}{$\mathrm{d}=$ descansada } \\
\hline \multicolumn{2}{|l|}{ e = envelhecida } \\
\hline 1 = envelhecida em tonéis de jequitibá & \\
\hline 2 = envelhecida em tonéis de castanheira & \\
\hline
\end{tabular}

